\title{
SOME CURRENT PROBLEMS IN PENNSYLVANIA LAW
}

\section{Reversible Error in Murder Cases and the Pennsylvania Supreme Court}

Long ago the United States Supreme Court decided that "due process" does not comprehend the right of appeal. ${ }^{1}$ Yet the history of our jurisprudence would indicate that judicial administration can ill afford to be without some process of appellate review. ${ }^{2}$ Practically speaking, its use seems an indispensable ingredient to our legal establishment. This is so, it is claimed, because no better methods can be devised for insuring fair decisions in trials, uniform and continued development of the law, and consistent, close supervision of trial judges. ${ }^{3}$ And, we may presume, it is the function of the appellate judiciary to secure these three interests. ${ }^{4}$ But though it may be easy to rationalize the existence of a court for appeals, the job becomes more difficult when one must appraise the work of a particular court in a particular field and seek to estimate the reality of what is being done.

On January 9, 1947, the Supreme Court of Pennsylvania decided Commonzealth $v$. John Jones. ${ }^{5}$ In that case, the defendant had been convicted of the murder of one Johnson, the other man in a love triangle. The jury recommended the death penalty. On appeal, the Supreme Court admitted "not the slightest doubt that the jury was entirely justified in finding that the killing was done with malice and that it was wilful, deliberate, and premeditated." But the court found error in the admission of evidence of prior arrests; and even though the charge limited the use

1. McKane v. Durston, 153 U.S. 684 (1894). See Dist. of Columbia v. Clawans, 300 U.S. 617, 627 (1937); compare Boykin v. Huff, 121 F.2d 865 (1941).

2. There was no appellate court in Georgia from 1776 to 1846 ; the early colonists detested courts and this antipathy was continued due to popular dissatisfaction with the decisions of John Marshall-particularly those which effected Georgia's right to grab Indian lands at will. During this period Georgia county judges tried to fill the need by assembling informally and reviewing their cases. At one time they even sought to invalidate a statute-an attempt which drew an immediate and violent reaction from the legislature. The condition of the law generally became so intolerable in the nineteenth century that the legislature finally authorized a Supreme Court, despite the fact that in a popular referendum an overwhelming majority of Georgia citizens still announced their disapproval of the project. Said one aged judge, after final establishment of a reviewing court: "Now lettest thou thy servant depart in peace, for mine eyes have beheld the salvation of the judiciary of Georgia." See Lamar, $A$ Unique and Unfamiliar Chapter in Our Legal History, 10 A.B.A.J. 513 (1924).

3. Orfield, Criminal Appfals in America 32-54 (1939).

4. On the review of criminal cases generally see Note 47 CoL. L. REv. 450 (1947); Hebert, The Problem of Reversible Error in Louisiana, 6 TULANE L. Rev. 169 (1932) ; Baker, Reversible Error in Homicide Cases, 23 J. CrIM. L. \& CRIMINOLOGY 28 (1932); 1 WrgMoRe, EVIDENCE $\$ 23$ (3d ed. 1940).

5. 355 Pa. 594, 50 A.2d 342 (1947). 
of such evidence to determination of sentence, it was reversible error "because the necessary effect was to mislead the jury."

Since this reversal, the Court has heard twenty-seven appeals from death sentences for first degree murder, and has affirmed the conviction in every case. The record on sentences of life imprisonment is not so extreme, but here too there is a strong tendency against upsetting jury verdicts. Are these decisions merely coincidental, or has such perfection in the conduct of homicide trials been attained that almost no reversals have been warranted in four years? Or is there a feeling on the part of the court that when a guilty man has been convicted the expense and effort of a new trial is not worthwhile except in extreme cases?

\section{HISTORY OF HARMLESS ERROR}

Prior to 1856 , the only method of review of criminal cases in Pennsylvania was by writ of error. This procedure brought to the appellate court only the pleadings and the docket entries; rulings on evidence and instructions could not be reviewed. ${ }^{6}$ The legislature in 1856 permitted review by bill of exceptions. ${ }^{7}$ The first case to reach the Supreme Court in this manner was Commonzealth v. Fife, ${ }^{8}$ and the opinion in that case set the tone of future decisions. The court reasoned that the legislature could not have intended "to obstruct the course of justice . . ., by opening the door to reversals upon mere technical and immaterial points in no way affecting the substantial merits of the case;" and therefore an appellant must show "that he may have been injured" by the trial court's error.

One principle was laid down in the Fife case which has not been apparent since. The Court there threatened to reverse for errors which might "operate injuriously as precedents in other cases." This has been considered unnecessary in subsequent cases; the Court feels that in holding a given error harmless it is nevertheless setting a precedent against repetition of the error. ${ }^{9}$

The other test set down in the Fife case has proved more durable, and has taken several forms. The original formulation was that if the appellant might possibly have been prejudiced as a result of the error, he was entitled to a new trial. The first variation from this statement was made in Commonwealth $v$. Daily (No. 2), ${ }^{10}$ wherein it was said of an erroneous instruction that it "should not cause a reversal, unless the reviewing court feels, not simply that the mistake in question possibly influenced the jury against defendant, but that it is strongly probable the verdict rendered reflects such adverse influence." The court saw no such probability here; in-

6. Hopkins v. Commonwealth, $50 \mathrm{~Pa} .9$ (1865). 1930).

7. Act of 6 Nov. 1856, P.L. 795; now PA. Stat. ANN., tit. 19, 11182 (Purdon

8. $29 \mathrm{~Pa} .429$ (1857).

9. See, for example, the discussion in Commonwealth v. Polens, $327 \mathrm{~Pa}$. 554, 194 At1. 652 (1937).

10. 280 Pa. 59, 124 Atl. 440 (1924) (italics added). 
deed, the evidence was characterized as "so strong that it leaves no doubt, reasonable or otherwise, as to the justice of [the] conviction." 11 Another change was presaged in the Divomte case, ${ }^{12}$ where the court stated that error was harmless unless it "contributed to the result reached by the jury." The conviction of Divomte was reversed, and therefore the language might have been dictum; but it was repeated as a holding in Commonwealth $v$. Schroeder. ${ }^{13}$ This seems to change the probability test laid down in the Fife case to a question of whether appellant was in fact prejudiced by the erroneous instruction of the trial court. At about the same time, in the Quaranta case, ${ }^{14}$ the court refused to reverse unless the error was "such that the inevitable effect would be to prejudice the jury or leave them without a requisite legal guide in a matter fundamental to the case."

These verbal changes are slight; it is extremely likely that when they first occurred the court was unaware of any difference at all. Between the two latter phrases-prejudice "in fact" and "inevitable" prejudicethere is probably no distinction. But the decisions in the Divomte and following cases sound a tone which was not audible earlier; even if the change of language was unconscious it seems to have been based on a shift in emphasis. The Fife case, for example, expresses the thought that even if the appellate court is convinced of the guilt of the defendant, an error should be corrected if on retrial a different verdict might result. ${ }^{15}$ By the time of the Daily case, however, the court apparently felt that since the defendant was guilty, the conviction should be affirmed. This is in fact a complete reversal of the earlier attitude. The mid-century court reversed if a jury might reach an opposite verdict, but refused itself to judge the defendant; the later court affirmed if a jury should reach the same verdict, and thus made an independent judgment of guilt.

\section{The Recent Verbal Formulations of the Rule}

In analyzing the present status of the harmless error rule, the doctrine of cure must be mentioned briefly. An error may be "cured" in several ways, including striking the testimony, subsequent admission of evidence wrongfully excluded, appearance of substantially the same testimony at a later stage of the trial, admissions of the defendant that the evidence wrongfully admitted against him is true, etc. The Fugmann case ${ }^{16}$ - the case most often cited on harmless error in Pennsylvania-was a case of cure. But this type of situation does not affect the problem which concerns us here, of when an uncorrected error requires a reversal.

11. $I d$. at 65,124 Atl. at 442 .

12. Commonwealth v. Divomte, 262 Pa. 504, 105 Atl. 821 (1919).

13. $302 \mathrm{~Pa} .1,152$ Atl. 835 (1930), quoting Commonwealth v. Winter, $289 \mathrm{~Pa}$. 284, 137 At1. 261 (1927), semble.

14. Commonwealth v. Quaranta, 295 Pa. 264, 145 At1. 89 (1928) (italics added).

15. Though the opinion says the evidence is not before the court, there is obviously some weight given the fact that "nearly every fact [in the confession] was proved by other witnesses before her statement was offered in evidence."

16. 330 Pa. 4, 198 Atl. 99 (1938). 
In the twenty-seven reviews of death sentences since the John Jones case, five have been decided on the basis of the harmless error rule. In the same period there have been, in addition, three cases involving lesser penalties, in which the rule has played a part. There have been several others in which the rule has been mentioned; but inasmuch as the court held there was no error in those trials, discussion of the harmless nature of what errors were alleged to have occurred must be considered as dicta. The present use of the rule must therefore be evaluated on the basis of eight cases.

Of these, Commonzealth $v$. Maloney ${ }^{17}$ sheds virtually no light on the problem, merely concluding that the issues "must have been entirely clear to the jury, and there was no error . . . sufficient to vitiate their verdict;" it does not give any indication of what errors would be sufficient.

Commonwealth v. Barnak ${ }^{18}$ is perhaps the most interesting of the cases. Barnak was accused of murdering his estranged wife and her escort. $\mathrm{He}$ was identified by several witnesses; the verdict found ample support in the evidence. The question raised on appeal was as to the accuracy of the charge with regard to the burden of proof of an alibi. The opinion of Chief Justice Maxey is so written as to support any of three theories: first, that the charge was not error; second, that the error was not prejudicial; third, that even though prejudicial it was cured by subsequent portions of the charge. Justice Patterson, in concurring, apparently believed the charge was erroneous, but considered it harmless since it had not "deprived the accused of his legal right to a fair trial." The opinion of the court uses similar language at one point. ${ }^{19}$ This holding (if it is a holding) once more rephrases the test of harmlessness. Indeed, a reformulation is essential to affirmance here. The jury was told to determine guilt or innocence beyond a reasonable doubt on the basis of the Commonwealth's evidence; and if the Commonwealth has proved every material allegation of the indictment they might then consider whether the defense of alibi raises such a doubt. But a jury deliberating on that basis would come to a conclusion of guilt which of itself would tend to minimize the defense testimony. ${ }^{20}$ Hence the only antecedent statement of the harmless error rule that would permit affirming here is the test of inevitability. Perhaps the Barnak case suggests a hesitation to require such an extreme showing of harm; at any rate the court set up a new formulation. And if in the Barnak case this was mere dictum, Commonzealth v. Holley ${ }^{21}$ expresses it as a holding. Justice Patterson, speaking for a unanimous court, there states that judicial comment on defendant's failure to testify was harmless because the phrasing of the comment "adequately protected"

17. 365 Pa. 1, 73 A.2d 707 (1950).

18. $357 \mathrm{~Pa} .391,54$ A.2d 865 (1947).

19. $I d$. at 419,54 A.2d at 878 .

20. See comment, 21 Pitt. L.J. 431 (1947).

21. $358 \mathrm{~Pa} .296,56$ A.2d 546 (1948). 
the defendant's rights; ${ }^{22}$ and the concurring opinion in the Barnak case was quoted at length to the effect that only a denial of the "right to a fair trial" would be grounds for reversal.

Commonzealth $v$. Neill ${ }^{23}$ is illustrative of the elasticity of the new formula. This is demonstrated by the ruling that the cross-examination of defendant's brother, regarding defendant's prior lascivious conduct, was harmless in view of the admission of lewd advances to the victim. Such a statement ignores the possibility that the defendant was irresistibly attracted by his victim but not by others, or that his conduct on the occasion of the murder was (at least in part) a new form of the mental disorders which had plagued him since boyhood. True, the court states that the testimony was admitted for impeachment purposes only; but there is always doubt of the jury's use of such evidence, and here there is at least some indication that the trial judge authorized consideration of the testimony as substantive evidence. ${ }^{24}$ Thus this error not only permitted the jury to consider evidence of an inflammatory nature; in doing so it also robbed the defendant of two possible theories in mitigation. The court's statement that such an error "did him no injury" can be explained in only two ways: the court either felt that in view of the facts a retrial must end in the same verdict, or was influenced in its decision by the "singularly abnormal and shocking" nature of the crime.

Chief Justice Maxey's concurring opinion also misinterprets the extent of the admissions which are held to make the admittedly erroneous ruling non-prejudicial. He adds only one element-that it was harmless because it did not "deprive the defendant of . . . a fair trial." 25

Commonwealth $v$. Moyer, ${ }^{26}$ in ruling on alleged prejudicial statements in the charge, follows the same formula. The trial court had referred to the defendants as "habitual criminals"; but this "harmless supererogatory indulgence . . . did not amount to a denial . . . of a fair trial."

Commonwealth $v$. Davis ${ }^{27}$ adds nothing to the prior decisions. The error was as to admission of testimony that defendant was a convict; but, as he later volunteered this information while he was himself on the stand, the harm was clearly cured.

22. His honor charged: "Introduced in evidence. . . was a statement made by the defendant when he was apprehended, . . . in which he confessed to the shooting and killing, and in which he gave his version of it. You will have to decide which version to accept, although I must point out to you that the defendant's version . . was not given from the witness stand, but it was included in the statement which he gave to the police. Do you believe that is an accurate statement, or do you believe, since he was charged with the crime, he was giving a statement of the facts calculated to sort of clear him somewhat? You see, he is the defendant here and you have to study his version of it in the light of his position in the case. He does not have to take the stand to testify on his own behalf if he does. not want to, and the fact that he does not is not to be taken as an admission of guilt of any particular degree of crime." Guilt had been conceded; the only issue was degree of crime.

23. 362 Pa. 507, 67 A.2d 276 (1949).

24. See opinion of Jones, J., dissenting, at 528, 67 A.2d at 284.

25. 362 Pa. 507, 523, 67 A.2d 276, 283 (1949).

26. $357 \mathrm{~Pa} .181,53$ A.2d 736 (1947).

27. 363 Pa. 91, 69 A.2d 123 (1949). 
Commonwealth $v$. Linkozeski $i^{28}$ again uses language of inevitability. The court states that no reversal will be required "where the conclusion [that defendant was not prejudiced] is inescapable." But the error here involved the procedure used by the Commonwealth in pleading surprise in order to cross-examine its own witness. Not only was the error of a technical nature; the testimony related to a phase of the case which was not disputed. Thus it would seem that even the most lenient of harmless error rules would uphold this particular decision. However, there is again reference to error which deprived the defendant of the right to a "fair trial".

An important corollary to the fair trial doctrine is illustrated by the Chavis case. ${ }^{29}$ There are holdings there that admission of deceased's clothing in evidence is not reversible error, though it serve no useful purpose; and that an argument which "could have been made . . . by the district attorney" was not reversible error when presented by the court. But the real value of the case lies in the discussion of the effect of incidents occurring before the jury was impanelled. The facts were that after the refusal of the court to order the removal of prospective jurors, a plea of guilty was withdrawn in their presence, and a plea of not guilty entered. Four of those present later sat in the same case; and counsel contended that their awareness of the withdrawn plea had the probative effect of evidence, though inadmissible. The Supreme Court ruled otherwise, relying on the charge that the jury might consider only the evidence in the case. ${ }^{30}$ The result is that if such a charge is given, errors occurring before the trial commences, no matter how prejudicial they may be, cannot be grounds'for reversal. This of course follows directly from the Barnak rule, since the denial of a fair trial can scarcely be postulated on incidents prior to trial. ${ }^{31}$

The accidental nature of this development of the harmless error rule cannot be overemphasized. The new formula was first stated in a concurring opinion; when it appeared as a holding, that opinion alone was cited. But there is no reason to believe that the new form of language was intended to change the law in the slightest degree. Nevertheless, the Chavis case indicates that a change has occurred. Chavis' conviction could hardly have been convincingly upheld were actual prejudice the issue; but in terms of "fair trial" there is good authority on both sides ${ }^{32}$ and a court approaching the question for the first time could rely on either theory. This is, then, a case where the form of language is important. If appeal from a conviction has been reduced to a pure question of due

28. 363 Pa. 420, 70 A.2d 278 (1950).

29. 357 Pa. 158, 53 A.2d 96 (1947).

30. Id. at $169,53 \mathrm{~A} .2 \mathrm{~d}$ at 101 .

31. Cf. Commonwealth v. Darcy, 362 Pa. 259, 66 A.2d 663 (1949), where a view was held not part of the trial and therefore would probably not permit reversal regardless of what might occur.

32. Trial by a prejudiced tribunal has been held to be a denial of due process, but with dictum that not all prejudices would be such. Tumey v. Ohio, 273 U.S. 510 (1927); id. at 522. 
process, then that fact should be clearly stated, and its effects thoroughly understood.

Unfortunately, the court has not yet seen fit to state the proposition that openly. "Fair trial" has been mentioned half a dozen times, but has yet to be defined. It is, after all, a legal conclusion; the incidents which constitute it are not readily apparent. The court has said that a jury which has in all probability made its decision in advance is not "unfair"; that it is not "unfair" to comment on defendant's failure to testify or to argue to the jury on the basis of facts without support in the evidence. But among all these negative decisions is not a single positive statement of the requirements of a "fair trial". The factors which influence the court to find "fairness" or "unfairness" must be gleaned from between the lines of its opinions.

\section{The Non-Doctrinal Formulation}

Some patterns of style and organization of the opinions emerge from a reading of the cases decided over a span of the last five years. There are also some recurrent themes which may form a basis of the court's thinking in general on this problem.

The usual opinion affirming a conviction begins by presenting-often in some detail-the theory and evidence of the Commonwealth. Seldom is the defendant's evidence given such full treatment. This technique is not in itself surprising. The court is required by statute to review the entire record to determine whether the "ingredients" of the crime have been proved; ${ }^{33}$ and in performing this duty it admittedly looks only to the prosecution's case since the elements of the crime must appear there and anything in the defendant's case merely raises a question of contradictory evidence which is for the jury. ${ }^{34}$ This statutory duty thus raises initial impressions of guilt in the mind of the court, which it apparently then feels it must vindicate. At times the opinions take extraordinary pains to demonstrate the sufficiency of the evidence against the accused. One opinion, seeking to disprove the defendant's alibi, is even replete with world track records and references to records of the existence or non-existence of moonlight on the night of the murder. ${ }^{35}$

This process-of demonstrating in detail the factual basis of the defendant's guilt-seems also to influence what is said in the opinions concerning the question of whether a given error is reversible. Having formed an independent judgment as to the facts, the court then shows itself impatient to dispose of alleged errors which if sustained could only obstruct infliction of what it believes to be a deserved penalty. Certainly the judges have expressed their desire to see swift execution of a predetermined sentence. ${ }^{36}$ The majority opinion in the Barnak case refers to the accused as "palpably" guilty and alludes to the futility and undesirability of re-

33. Pa. Stat. ANn., tit. 19, $\$ 1187$ (Purdon 1930).

34. Commonwealth v. Karmendi, $328 \mathrm{~Pa}$. 321, 195 At1. 62 (1937).

35. Commonwealth v. Barnak, $357 \mathrm{~Pa}$. 391, 54 A.2d 865 (1947).

36. "Committing a wrong against an accused cannot be righted by committing a wrong against society;" Commonwealth v. Turner, $358 \mathrm{~Pa} .350,58$ A.2d 61 (1948). 
versing convictions and delaying the punishment of proven criminals. ${ }^{37}$ The killing in the Chavis case was found to be "malicious and brutal;" the defendant had clearly revealed himself as a murderer deserving the penalty of death. ${ }^{38}$ Johnson's crime was described as "extremely dastardly." 39

Often the court uses vivid adjectives in describing the evidence in a particular case. Where a crime was thought to be particularly shocking, the opinion says so. In the Gibbs case the evidence was said to present "a picture of a brutal and ruthless crime." 40 In the Chapman case, Justice Maxey made the forceful, albeit perhaps extra-judicial, statement that "His [defendant's] murder-lust not being satisfied he then shot his wife's dog and laid it on her arm." 41 In the Neill case it was said: "The crime was singularly abnormal and shocking." And again: ". . . He murdered her cruelly and repulsively by strangulation, and then with almost incredible callousness left her body exposed to decomposition by the elements. . . " ${ }^{42}$ Indeed in that case Justice Jones, dissenting, warned his brethren to be "on guard lest revulsion displace reason and so blind one to the possible presence of harmful error." 43

In addition to indicating a desire to see the guilty promptly punished, the court has expressed impatience with assignments of what it regards as minor errors.

"Taking an appeal in criminal cases is not a game," warned Justice Maxey, "in which appellant wins if he can show that the trial judge fell a few degrees short of perfection in the conduct of his trial. This court has consistently refused to reverse convictions of murder in the first degree, even with the death penalty imposed, for errors in the judge's charge when these errors did not deprive defendant of the fundamentals of a fair trial." 44 That exact language was quoted with approval in a later case. ${ }^{45}$ Moreover, the court has announced that it affirms convictions even where there are "manifest" errors in the record. ${ }^{48}$ Twice Justice Maxey alluded to remarks delivered half a century ago by Justice Taft-remarks to the effect that the American appellate courts at that time were all too willing to reverse for inconsequential technicalities. ${ }^{47}$ And in the Darcy case it was argued that to reverse for the error alleged would be "carrying technicalities to fantastic lengths." 48

37. 357 Pa. 391, 421, 54 A.2d 865, 879 (1947).

38. $357 \mathrm{~Pa} .158,175,53$ A.2d 96, 104 (1947).

39. $365 \mathrm{~Pa} .303,319,74$ A.2d 144, 151 (1950).

40. $366 \mathrm{~Pa} .182,192,76$ A.2d 608, 613 (1950).

41. 359 Pa. 164, 170, 58 A.2d 433, 436 (1948).

42. $362 \mathrm{~Pa} .507,518,67$ A.2d 276, 281 (1949).

43. Id. at 523, 67 A.2d at 284.

44. Commonwealth v. Barnak, 357 Pa. 391, 419, 54 A.2d 865, 878 (1947).

45. Commonwealth v. Neill, 362 Pa. 507, 519, 67 A.2d 276, 282 (1949).

46. See Commonwealth v. Barnak, 357 Pa. 391, 419, 54 A.2d 865, 878 (1947).

47. Commonwealth v. Darcy, $362 \mathrm{~Pa} .259,272,66$ A.2d 663, 670 (1949) ; Commonwealth v. Barnak, $357 \mathrm{~Pa}$. 391, 419, 54 A.2d 865, 879 (1947).

48. 362 Pa. 259, 272, 66 A.2d 663, 670 (1949). 
Perhaps it is this reaction against technicality which influences the court to adopt a seemingly tolerant attitude in countenancing trial court errors of discretion. Seldom in the opinions can one find stern instructions to the lower judiciary, even where it is found that error has been committed.

A frequent example of this tolerance involves the introduction of evidence such as photographs of the victim's body and remnants of the victim's clothing. When the admission of such evidence has been challenged on appeal the court has repeatedly said that the problem is one to be solved in the first instance by the discretion of the trial judge. And, as the court itself said in the Simmons case, the use of such admittedly dangerous evidence "has been so frequently sanctioned and declared unobjectionable by repeated decisions of this court, that assignments of error based on . . . [its] admission call for no extended discussion." 49 This abdication pronouncement was reiterated verbatim in the Gibbs case. ${ }^{49 a}$

Of course the court has briefly indicated the obvious dangers inherent in that procedure, and it has noted the requirement that the judge must "instruct" the jury that they are not to become aroused at the sight of sickening exhibits. But the court has expounded little on when the need arises for the introduction of such evidence, and presumably only if a real need exists should it be admitted. Seldom has the court made a determination based on the circumstances and requisites of proof in each individual case, whether there was an actual need for the admission of the evidence in that case.

Another example of tolerance as to discretionary matters is the Watts case, ${ }^{\tilde{0}}$ where the trial court made it clear that he was "astonished" at the testimony of one of the defendant's witnesses. In his comment on the evidence during the charge he again demonstrated his belief as to its credibility ("he was obviously aiming to put the jury on the alert. ...") The Supreme Court agreed that trial judges must not abuse their power to comment on the evidence and must not "magnify the evidence on one side and belittle it on the other." But it was said that because here there was an "atrocious" crime, and an "apparently fabricated defense" the trial court had not over-reached itself. No warning or manifestation of displeasure ensued. In other cases where the trial judge's comments have on appeal been alleged as error the court has demonstrated a willingness to abstain from any role of policing this area of discretion. Within recent years only in the Broechey case ${ }^{51}$ has the court pointedly directed a trial judge and a district attorney to refrain from "over zealous" attempts to secure conviction. This was one of the two reversals of convictions with life sentences in the past four years.

49. 361 Pa. 391, 397, 65 A.2d 353, 356 (1949).

49a. $366 \mathrm{~Pa} .182,186,76$ A.2d 608, 610 (1950).

50. Commonwealth v. Watts, $358 \mathrm{~Pa} .92,56 \mathrm{A.2d} 81$ (1948).

51. Commonwealth v. Broeckey, $364 \mathrm{~Pa} .368,72$ A.2d 134 (1950). 
There are other instances where the court has indicated that the trial court may have exceeded its discretion and yet has not used firm language to indicate displeasure at such abuse. The court steadfastly and passively insists that defective excerpts in a charge may be considered cured if upon review the charge as a whole is believed to have conveyed the correct impression to the jury.

In the Barnak case ${ }^{52}$ the trial court erroneously charged that the burden was on the defendant to prove that his alibi was a defense to the crime. No criticism of the charge was made by the court. In a footnote it was suggested that lower courts should henceforth take note that both the charge and the cases from which it stemmed were to be considered bad law, but in the opinion itself the court took pains to vindicate both the charge and the legal theory which supported it. If such a charge is erroneous, an opinion supporting it can only cause confusion in the law.

The same danger appears in the Gibbs case, ${ }^{53}$ where the defendant pressed the point that the trial judge had improperly charged that a legal presumption of intent to kill arises from the use of a deadly weapon. Quite clearly the court has held that no legal presumption arises from the use of a deadly weapon, that the jury may draw only an inference of fact.54 Yet the court affirmed the Holley conviction despite the charge that "the fatal use of a deadly weapon against a vital part of another's body . . warrants an inference ... [of] intent to take life... [and] the jury has a perfect right, I should say almost the duty, legal duty, of saying that there was an intent to take the life." 55 This charge, it was admitted, "cannot be approved"; but disapproval in 1948 was not enough to prevent the subject from arising again in 1950. This time the court did not even make the effort to point out the need for correcting the mistake. ${ }^{56}$

The court often shows annoyance at defenses which it believes to be fictional. In the Watts case ${ }^{57}$ it was stated that the trial court had not abused its discretion in view of the "apparently fabricated defense". Chief Justice Maxey, concurring in the Chapman case, dismissed defendant's testimony with the comment that "considerations of calculated policy policy were in the ascendant." 58

Undoubtedly it is dangerous to draw too many conclusions from a random sampling of the opinions. No doubt such a sampling does not tell the full story of the judicial process of reviewing murder convictions in Pennsylvania. Yet courts are governmental agencies, just as are legislatures and executive bodies. The written opinion is the judge's fiat. Not

52. $357 \mathrm{~Pa} .391,54$ A.2d 865 (1947).

53. 366 Pa. 182, 76 A.2d 608 (1950).

54. Commonwealth v. Kluska, 333 Pa. 65, 3 A.2d 398 (1939).

55. $358 \mathrm{~Pa} .296,302$, 56 A.2d 546, 549 (1948).

56. Commonwealth v. Gibbs, $366 \mathrm{~Pa} .182,76$ A.2d 608 (1950).

57. Supra note 50.

58. 359 Pa. 164, 171, 58 A.2d 433, 436 (1948). 
only what they decide but also how they decide are critical questions to those who would understand the law and its practical workings.

Were one to examine carefully the evidence in the cases discussed above, there would not be too much cause to doubt that the Pennsylvania court has seen to it that the guilt of those convicted of homicide is adequately proved. If one were to criticize the court he would have to depart from the official opinions and records to establish the basis of an argument that innocent men have been convicted of crimes. It is not so much on the score that the court has affirmed too often, but that affirmance has been too easy, that criticism may arise.

\section{What Is ReVerstble ERror}

To formulate any "rule" or "test," which will determine the issue to reverse or not to reverse for errors in the record, is well nigh impossible. But it is possible for a court to adopt a theory-a policy-which will control the disposition of the appeal.

What are the possible approaches? Judge Jerome Frank has essayed the task with much care. ${ }^{59} \mathrm{He}$ suggests that there are three courses. First, a court may reverse for all errors. This is the old "Exchequer rule"-employed briefly in England, and widely during the early nineteenth century in the United States. ${ }^{60}$ It is easy to damn so technical a doctrine, for such a rigid standard quite obviously can obstruct justice. But historically speaking, the "Exchequer rule" may have played a vital part in producing much case law to buttress the criminal jurisprudence of this country.

Second, a court may presume prejudice from any error-except one of pure form-and require the prosecution to show that despite the mistake, no sensible jury could have acquitted. Of course this theory introduces the element of conjecture and hence loses as much in precision. But only to a limited degree. For here the judges do not determine guilt, nor do they evaluate credibility. The sole end of investigation is: could the mistake itself possibly have played a part. If so there is a mandate to reverse.

59. See his dissent in United States v. Antonelli Fireworks Co., 155 F.2d 631, at $642(1946)$.

60. Orfield, Criminal Appeals In America 190 et seq. (1939); 1 Wigmore, EVIDENCE $\$ 21$ (3rd ed. 1940). See also Kavanagh, Improvement of Administration of Criminal Justice by Exercise of Judicial Power, 11 A.B.A.J. 217 (1925) for a blast at the obstructive technicality of upper courts during the early twentieth century.

Reaction to repeated reversals for technicalities led to the adoption of Article VI $\$ 4 \frac{1}{2}$ of the California Constitution which states:

"No judgment shall be set aside, or new trial granted, in any case, on the ground of misdirection of the jury, or of the improper admission or rejection of evidence, or for any error as to any matter of pleading, or for any error as to any matter of procedure, unless after an examination of the entire cause, including the evidence, the court shall be of the opinion that the error complained of has resulted in a miscarriage of justice."

The mandate embodied in the above provision would appear to have been strictly followed by the California courts, as statistical inquiry has shown a marked 
Third, a court may decide for itself whether a reasonable basis for guilt exists, with the error elided from the record. For necessarily, on reading the record, the judges would ignore that done below which was contrary to law. And on finding a sufficient basis of guilt notwithstanding the error the court decides that it is harmless. ${ }^{61}$

The refinement which distinguishes the second from the third test is that in the former there is to be no consideration of actual guilt on review. Conjecture is limited to guessing what a reasonable jury could conceivably do.

Perhaps Judge Frank's distinctions are too subtle. In a vacuum they present logical distinction, but in a hard case how much guidance may they afford? Minds will always differ whether a sensible juror could sensibly come to any other conclusion. And in deciding that issue it would seem that the reviewing judge must decide for himself how strong was the prosecution's case. And so deciding, can he possibly banish from his thoughts his own impressions as to guilt?

At any event, it is submitted that there are other considerations of which account should be taken when the scales are to be tipped in a closely balanced case. The court should depart from the record, and from the question of whether the defendant was given all which the law entitled him to get. The impact which a countenancing of the error would have on the correct development of the law must be considered as well. For if what was done below should not have been done, the task devolves on the appellate court to take appropriate steps to see that mistakes of a like nature are not duplicated again. Whether or not the fulfillment of this duty requires a reversal is of course open to question. But whatever the answer, a court should articulate the reasons which prompt it.

Of course the appellate court's first duty is to assure proper application of the law to individual cases. The right to question rulings of a lower

decline in criminal reversals by the supreme court since the adoption of the provision. A commonly found statement in cases which affirm conviction despite error is that the provision abrogates the old rule that prejudice is to be presumed from any error of law. E.g. People v. O'Bryan, 165 Cal. 55, 63-66, 130 Pac. 1042 (1913).

Research shows the following results as regards the reversal of murder convictions in California in the last five years:

\begin{tabular}{|c|c|c|c|c|}
\hline Year & $\begin{array}{l}\text { Affirmed } \\
\text { No Error }\end{array}$ & $\begin{array}{c}\text { Affirmed } \\
\text { Harmless Er. }\end{array}$ & Reversed & $\begin{array}{l}\text { Per Cent } \\
\text { Reversed }\end{array}$ \\
\hline $\begin{array}{l}1946 \\
1947 \\
1948 \\
1949 \\
1950\end{array}$ & $\begin{array}{l}6 \\
4 \\
2 \\
6 \\
4\end{array}$ & $\begin{array}{l}8 \\
6 \\
3 \\
3 \\
4\end{array}$ & $\begin{array}{l}2 \\
0 \\
4 \\
0 \\
0\end{array}$ & $\frac{13}{43}$ \\
\hline Total & 22 & 24 & 6 & $\overline{11.5 \%}$ \\
\hline
\end{tabular}

In earlier years the California Court was not so moderate. During the period 1850-1926 the court affirmed 3,236 cases, and reversed 1202. From 1850 to 1859 it reversed over $50 \%$ of all cases. From 1900 to 1909 the figure dropped to $25 \%$. See Vernier \& Selig, The Reversal of Criminal Cases In the Supreme Court of Califormia, 20 J. CRIM. L. \& CRIMINology 60 (1929).

61. United States v. Antonelli Fireworks Co., 155 F.2d at 648. 
court should certainly be limited to a party who has been harmed by their incorrectness; in this sense the harmless error rule partakes of the problem of standing to appeal. But an appellate court also is responsible to some extent for the administration of the lesser tribunals, and it is to this end that prophylactic rules are sometimes adopted, as sanctions to prevent repetition of errors. In recent years the Pennsylvania Supreme Court has minimized this aspect of judicial review, and has approached the position that as against a guilty individual, no error is prejudicial.

Yet in the same period of time the public's attention has been directed with ever increasing frequency to instances where law enforcement officials have disregarded the common rules of decency and fair play which are the very essence of ordered liberty. ${ }^{62}$ It is because these instances are known to occur from time to time, that the appellate court should exercise a delicate function-a dual task-of assuring not only the efficient application of the penal law to the criminal population, but also its fair application in every case.

\section{Attorney General versus District Attorney}

Just as Pennsylvania politicians were warming up for a bitter election campaign, news of graft by top officials of Pittsburgh's Democratic administration was broken by Charles J. Margiotti, a widely known lawyer and former state attorney general. ${ }^{1}$ It appeared that city labor and materials had been used to pave private roads and driveways outside the city. The husband of Mr. Margiotti's client had been killed while engaged in some of this free city work. Pittsburgh's city solicitor immediately started an investigation which dragged on for six weeks without result. Then city council conducted hearings which concluded with mild admonition to the officials involved. At this point the Democratic district attorney announced that he would make a complete investigation and, at his request, the grand jury was recalled for this purpose. Shortly thereafter Pennsylvania's Republican governor announced the appointment of Mr. Margiotti as state attorney general. The new Attorney General immediately served an order of supersession on the district attorney and petitioned the county court to dismiss the grand jury. This court denied the petition and revoked the supersession on the ground that the Attorney General had abused his discretion. The Attorney General promptly placed this delicate matter before the supreme court. Both rulings of the lower court were there reversed on the premise that the Attorney General has discretionary common law

62. The most recent example of this is the Sheeler case; see Philadelphia Inquirer, April 6, 1951, p. 1, col. 2.

1. Early developments received daily front page coverage, Pittsburgh Post Gazette, April 27, 1950, et seq. See particularly id., June 24, 1950, p. 6, col. 1, and July 3,1950 , p. 6 , col. 1 . 
power to supersede a district attorney in any investigation and had not abused his discretion. ${ }^{2}$

Many courts have said that a state attorney general has all the powers of his predecessor at common law. ${ }^{3}$ Upon this comfortable generality are based decisions which affirm the exercise of a variety of specific powers by state attorneys general. ${ }^{4}$ The courts, however, have seldom gone beyond the facts of a particular case to indicate the nature and limits of these common law powers. ${ }^{5}$ It is fairly clear that the accepted model is the preRevolution English attorney general. ${ }^{6}$ From this it should follow that common law powers of a state attorney general are the same as, or analogous to, those actually exercised by his English forebear. There is little doubt that the 18th Century English attorney general exercised wide powers of supervision over all criminal investigations and prosecutions. ${ }^{7}$ Furthermore, he apparently could assume personal control of such proceedings whenever he saw fit. 8 However, at that time he was the only public officer in the English system of private prosecution, which knew no counterpart of the American district attorney. ${ }^{9}$ Certainly he could not have exerted his power of supersession over a non-existent officer. Nor is there a convincing analogy between the English and the instant cases of supersession; the former displaced only a private individual while the latter ousts an elected official who is required by law to investigate such matters. Nonetheless the court held, solely on the basis of its own prior

2. In re Grand Jury Investigation of Violations of Law in -Use of City Labor and Materials of City of Pittsburgh, $365 \mathrm{~Pa} .330,75 \mathrm{~A} .2 \mathrm{~d} 465$ (1950). Jones and Ladner, JJ., dissented.

3. The leading Pennsylvania case is Commonwealth ex rel. Minerd v. Margiotti, $325 \mathrm{~Pa}$. 17, 188 Atl. 524 (1936). Other jurisdictions are discussed in DeLong, Powers and Duties of the State Attorney-General in Criminal Prosecution, $25 \mathrm{~J}$. Crar. L. \& Criminology 358, 361-372 (1934).

4. In general, 7 C.J.S. 1222 (1937). No case has been found in which supersession of a district attorney has been approved on the basis of common law powers. The attorney general may assist in prosecution, State v. Robinson, 101 Minn. 277, 112 N.W. 269 (1907). Where a statute authorized supersession, it has been held: valid, In re Watson, 293 Mich. 263, 291 N.W. 652 (1940); invalid, where district attorney was ready and willing to continue, People v. Flynn, 375 I11. 366, 31 N.E.2d 591 (1941); and unconstitutional, Kemp v. Stanley, 204 La. 110, 15 So.2d 1 (1943). In the absence of statutory authority it has been held the attorney general may not appear before a grand jury, People v. Hopkins, 47 N.Y.S.2d 222 (1944).

5. See, e.g., Commonwealth ex rel. Minerd v. Margiotti, $325 \mathrm{~Pa} .17,21$. An exception which is often quoted but cites no authority is People v. Miner, 2 Lans. 396 (N.Y. 1868).

6. See, e.g., Commonwealth ex rel. Minerd v. Margiotti, $325 \mathrm{~Pa} .17,21,188$ Atl. 524, 526 (1936).

7. His powers seem to be taken for granted, are not well defined, 1 STEPHEN, History of the Criminal Law of England 499 (1883).

8. Archeold, Crminimal Pleading, Evidence and Practice 103 (1943).

9. Howard, Criminal Justice in England c. 1 (1931); Jackson, The MACHINERY OF JUSTICE IN ENGLAND 106 (1940). The office of district attorney was not created in Pennsylvania until 1850, 16 PA. STAT. ANN. \$1691 (1930). In 1879 the English created the office of Director of Public Prosecutions, but this officer handles only important prosecutions and is subordinate to the attorney general, HoWARD, op. cit. supra, 78. 
dicta, ${ }^{10}$ that the State Attorney General derives from the common law a discretionary power to supersede a district attorney in any investigation of crime.

Stronger support for the court's position could have been found in the statutes which provide that the Attorney General of Pennsylvania shall have the power "to take such steps, and adopt such means, as may be reasonably necessary to enforce the laws of the Commonwealth." 11 Although the statute has been little used, the language would appear to be sufficiently broad to allow the instant result. The court's failure to use the statute may be attributable to a suggestion that the statute simply preserves the Attorney General's common law powers. ${ }^{12}$ This interpretation, of course, should defeat any use of the statute for the reasons already set forth.

The dubious reasoning in this case would seem to indicate that the court was straining to justify what it thought to be a desirable result. There is here no question of limiting the Attorney General's jurisdiction; he may at any time conduct his own investigation..$^{13}$ Nor is there any question that in certain situations a district attorney should be replaced; he may be negligent, biased, incompetent, or dishonest. The sole question is whether the Attorney General himself should decide when that occasion arises. To answer this question it must be recognized that the issue of supersession will ordinarily be raised, as it was here, in a political context. ${ }^{14}$ Immediate doubt arises as to the advisability of vesting such discretion in an appointed official. ${ }^{15}$ Furthermore, there seems no need to add supersession by the Attorney General to the existing procedures for removing a district attorney. The Pennsylvania Constitution provides that a district attorney may be removed upon impeachment, ${ }^{16}$ conviction of misbehavior in office or an infamous crime, or for other reasonable cause. ${ }^{17}$ The legislature has further provided that in appropriate cases the president judge of a county court may at his discretion request the Attorney General to appoint a special prosecutor to supersede the district attorney. ${ }^{18}$ While it may be that the constitutional processes are too cumbersome for efficient use, it would seem that the statutory procedure has decided advantages

10. Commonwealth ex rel. Minerd v. Margiotti, supra (district attorney voluntarily withdrew and court requested Attorney General's intervention); In re Dauphin County Grand Jury, 332 Pa. 289, 2 A.2d 783 (1938) (denial of governor's petition for writ of prohibition; see note 20 , infra). For an ingenious but unconvincing theory in support of Attorney General's power to supersede a district attorney, see Commonwealth v. Lehman, $309 \mathrm{~Pa} .486,164$ Atl. 526 (1932).

11. 71 Pa. Stat. ANn. \$294(b) (1942).

12. Commonwealth ex rel. Minerd v. Margiotti, supra at 33, 188 Atl. at 531.

13. 71 Pa. Stat. Ann. \$294(a) (1942).

14. See articles cited in note 1 supra. See also In re Dauphin County Grand Jury, supra, in which the political implications are clear. elected.

15. Pennsylvania is one of the few states in which the attorney general is not

16. Pa. Const. Art. VI, $\S 3$.

17. Id. Art. VI, §4.

18. 71 Pa. Stat. Ann. $\$ 297$ (1942). 
over action inspired by the Attorney General. The president judge has greater familiarity with the local situation and better opportunity to observe the activities of the district attorney. ${ }^{19}$ In addition, it must be assumed that a member of the judiciary is less susceptible to political influence. Also of importance is the expressed preference of the legislature which has retained for many years the statute vesting discretion in the president judge but rejected, after a short trial, a provision giving the same discretion to the Attorney General. ${ }^{20}$ Despite this combination of factors, the court, for reasons it did not reveal, chose the alternative and characterized a modern cabinet official serving in a democratic state as an officer of the 18th Century monarch.

\section{Removal of Public Officers in Pennsylvania: The Constitutional Provisions}

Recent proceedings against W. Frank Marshal1, ${ }^{1}$ Receiver of Taxes for the City of Philadelphia, and current proceedings against various public officials in Pittsburgh have stirred interest anew in the problem of how to remove public officers. Research in Pennsylvania law reveals a large body of statutes pertaining to the removal of state, county, and municipal officers, ${ }^{2}$ but five basic removal provisions of the Pennsylvania Constitution, and the very considerable case law construing them, are of

19. There are 67 district attorneys, 58 judicial districts with over 150 common pleas judges, only one Attorney General.

20. Act of July 30, 1938, P.L. 17, passed at the so-called "Whitewash Session," empowered the Attorney General at his discretion to supersede the district attorney in any investigation. This act was passed to thwart a grand jury investigation of the governor. Less than a year later the legislature repealed the act without remorse, Act of March 20, 1939, P.L. 8. See 22 PA. LEGIs. J. 12-15, 38-42, 62 (1938); 23 Id. 414-415, 465-468, 624 (1939).

1. Marshall was acquitted of charges alleging mismanagement of his office. Before trial two appeals were taken to the Pennsylvania Supreme Court. The proceedings lasted over a year and a half. See Marshall Impeachment Case, $360 \mathrm{~Pa}$. 304, 62 A.2d 30 (1948); Marshall Impeachment Case, $363 \mathrm{~Pa} .326,69$ A.2d 619 (1949).

2. Some statutes, specifying criminal sanctions for certain types of conduct of public officers, also provide for removal. See, e.g., PA. STAT. ANN. tit. 18, $\$ \$ 4682$ (interest in public contracts) 4679 (loaning public money), 4680 (investing public money) (Purdon, 1931). Provision for removal of school directors is made by e.g., PA. Stat. AnN. tit. 24, §§ 180, 183-4, 786, 341, 1003, 10441067 (Purdon, 1931). Specific county officers have been made the subject of removal provisions. E.g., PA. Stat. ANN, tit. 16, $\$ \$ 1459,1461$ (County Treasurers); 162, 1494 (County Surveyors) ; $\$ \$ 2343,2393$ (Sheriffs, Coronors, Controllers, Prothonotaries, and Clerks of Courts in Counties of the Fifth Class); $\$ \S 2438,2463$ (similar offices in Counties of the Sixth Class; $\$ \$ 2513$ (Sheriff in County of the Eighth Class) (Purdon, 1931). Provision for removal of municipal officers is separately made for each class city. See, e.g., PA. STAT. ANN. tit. 53, $\$ 3001-7$ (First Class Cities); $\$ \$ 9461-9468$ (Second Class Cities); $\$ \$ 10791$ (a) (Cities of Second Class A); $\$ \S 12198-901,-905,-908,-910,-912,-913,-914$ (Third Class Cities). (Purdon, 1931). 
supreme importance, for they form the sole basis for the removal of officers named in the Constitution. ${ }^{3}$

The Constitution provides for the removal of all public officers through impeachment by the legislature. ${ }^{4}$ Further, there is automatic removal if any public officer is either convicted of the offense of misbehavior in office, or of infamous crime. ${ }^{5}$ Provision is also made for the removal of most elected officers by the Governor after full notice and hearing at the address of two-thirds of the Senate, ${ }^{6}$ and for removal of appointed officers, with two exceptions, by the appointing power. ${ }^{7}$ This Note represents an examination of these important provisions, ${ }^{8}$ and suggestions are offered with a view toward elimination current inconsistencies and shortcomings.

\section{Types of Office Holders}

Before considering the removal provisions of Pennsylvania's Constitution, three types of office holders should be distinguished. The distinctions are important because the applicability of a Constitutional provision varies with the type of officer sought to be removed. For instance, the legislature has complete power to provide for the removal of "employees" and "non-constitutional" public officers, but it cannot govern the removal of "constitutional" public officers. For this latter type, a Constitutional provision is controlling.

The contrast between a "public officer" and an "employee" is easily perceived where a state governor is juxtaposed to a city hall elevator operator. However, the line is more dimly seen when a troop captain of police is held to be a public officer. ${ }^{9}$ The term "employee" generally refers to such persons as policemen, firemen, and personnel of the Civil Service. ${ }^{10}$ In contrast a "public officer" is a person whose duties "are of a grave and important character, involving in the proper performance of them some of the functions of government." 11 The tests seem to be "whether the duties are designated by statute, whether the incumbent serves for a fixed

3. The legislature cannot provide for the removal of such officers. Bowman's Case, 225 Pa. 364, 74 Atl. 203 (1909) ; Marshall Case, 360 Pa. 304. 62 A.2d 30 (1948); In Re Turner, 36 D. \& C. 448 (Pa. 1939).

4. PA. Constit. of 1874, Art. VI, §§ 1-3. See, e.g. Com. v. Likeley, 267 Pa. 310, 110 Atl. 167 (1920); Richie v. Phila., 225 Pa. 511, 74 Atl. 430 (1909).

5. Pa. Constit. of 1874, Art. VI, § 4.

6. Ibid.

7. Ibid. The exceptions are Sup't of Public Instruction and appointed judges.

8. Removal of judges, other than Supreme Court Justices, may be accomplished by the Governor with the concurrence of two-thirds of each House. PA. Constit. of 1874, ART. V, $\$ 15$. Supreme Court Justices hold office so long as they behave themselves well. PA. Constrt. of 1874, ART. V. \$2. Judges are "Constitutional" officers; hence our discussion of removal of constitutional officers will therefore be pertinent to the removal of judges.

9. Com. v. Miller, $94 \mathrm{~Pa}$. Super. 499 (1928).

10. Examples of "employees": elevator operator foreman, Sailer v. Phila., 273 Pa. 424, 117 Atl. 272 (1922) ; clerk of Dept. of Docks, Com. v. Hassakar, 21 Dist. 119 (Pa. C.P. 1912); policeman, Saul v. City of Scranton, 9 Dist. 156, (Pa. C.P. 1900).

11. See Richie v. Phila., 225 Pa. 511, 515, 74 Atl. 430, 431 (1909). 
term, acts under oath, or gives a bond, and the source or character of the compensation received." 12 Though this definition appears to be vague, a number of decisions are available to argue a particular case. The term "public officer" includes county officers such as recorders of deeds, and municipal officers such as mayors. ${ }^{13}$

Within the group known as "public officers" we must make a further subdivision. A "constitutional" officer is a public officer whose office is established by the Pennsylvania Constitution, "one which the Legislature did not create and cannot abolish." 14 A very large majority of the more important Pennsylvania officers are "constitutional" ones. In addition to Governor, Lieutenant Governor, and judges, the list includes county officers such as commissioners, surveyors, etc. ${ }^{15}$ As has been noted, the important fact about constitutional officers, so far as removal is concerned, is that the Legislature can provide no method to remove them. ${ }^{16}$ "NonConstitutional" officers constitute the balance of public officers, and since they are created by the Legislature, they may be removed by a method provided by the Legislature. ${ }^{17}$

It has long been held that the provision of the Pennsylvania Constitution referring to appointed public officers has no application to em-ployees. ${ }^{18}$ And dictum of the Pennsylvania Supreme Court has consistently dismissed the applicability of all the Constitutional provisions so far as "employees" are concerned. ${ }^{10}$ Thus, one may be removed under statutory Civil Service procedure if it be determined that he is an employee; but if it is decided that he has the status of "public officer," rather than "employee," that procedure is inapplicable, and if the Legislature has

12. See Saar v. Hanlon, 163 Pa. Super. 143, 60 A.2d 432 (1948).

13. Examples of "public officers": School Board Treasurer, Muir v. Madden, 286 Pa. 233, 133 Atl. 226 (1926) ; Chief of Bureau of City Property, Arthur v. Phila. $273 \mathrm{~Pa}$ 419, 117 Atl. 269 (1922) ; City Clerk, Com. v. Likeley, $267 \mathrm{~Pa} .310,110$ Atl. 167 (1920); Warden of County Prison, Morgan v. Adamson 4 D. \& C. 77 (Pa. C.P. 1923).

14. Bowman's Case, 225 Pa. 364, 74 Atl. 203 (1909); In Re Turner, 36 D. \& C. 448 (Pa. C.P. 1939); See Marshall Impeachment Case, 360 Pa. 304, 62 A.2d 30 (1948).

15. Offices for which provision in the Constitution is made are those of: Governor, Lt. Governor, Judges, Members of the House and Senate, Sect'y of the Commonwealth, Attorney General, Auditor General, State Treasurer, Sect'y of Internal Affairs, Sup't of Public Instruction, Justices of the Peace, Aldermen, Phila. Magistrates, Sheriffs, Coroners, Prothonotaries, Registers of Wills, Recorders of Deeds, County Commissioners, County Treasurers, County Surveyors, County Auditors or Controllers, Clerks of the Courts, District Attorneys. PA. Constit. of 1874 ART. II, \$1, 9; ART. IV, §1; ART. V, §1, ART. XIV, \$1.

16. Bowman's Case, $225 \mathrm{~Pa}$. 364, 74 Atl. 203 (1909); Marshall Case, $360 \mathrm{~Pa}$. 304, 62 A.2d 30 (1948); In Re Turner, 36 D. \& C. 448 (1939).

17. Weiss v. Ziegler, $327 \mathrm{~Pa} .100,193$ Atl. 642 (1937), Milford Tp. Supervisor's Removal, 291 Pa. 46, 139 Atl. 623 (1927).

18. See, e.g., Com. v. Black, 201 Pa. 433, 50 Atl. 1008 (1902); Houseman v. Com., $100 \mathrm{~Pa} .222$ (1882).

19. See Com. ex rel. Houlahen v. Flynn, $348 \mathrm{~Pa} .101,103,34$ A.2d 59, 60 (1943) Arthur v. Phila., $273 \mathrm{~Pa} .419,423$, 117 Atl. 269, 270 (1922); Com. v. Black, 201 Pa. 433, 436, 50 Atl. 1008, 1009 (1902). 
made no provision for removing such a public officer, he is only removable under a provision of the Pennsylvania Constitution. ${ }^{20}$

The following discussion of the removal provisions is divided into two parts. The first considers provisions applicable to all public officers; the second looks at provisions which may or may not be applicable to a particular public officer depending upon whether or not he is a "constitutional" officer.

\section{Removal Provisions Applicable to All Public Officers}

Impeachment.-The Pennsylvania Constitution provides for impeachment of all civil officers for any misdemeanor in office. ${ }^{21}$ "Civil" officers are public officers other than military.22 The Pennsylvania House of Representatives has the sole power of impeachment, the Senate tries the cause, and judgment by the Senate may extend further than removal so as to perpetually disqualify a person from holding public office. ${ }^{23}$ This latter event is only possible in impeachment.

The judiciary is not involved in the proceedings except as there may be a violation of the Assembly's constitutional authority. ${ }^{24}$ The Pennsylvania court has expressed its intention to limit Constitutional impeachment to the plain meaning of the Constitution, and has said that "for crimes not misdemeanors in office impeachment may not be brought." 25 The court has likewise defined an impeachable offense as being "a criminal act in the course of conduct of the office." 26 Clearly the language indicates that a man cannot be impeached for conduct disconnected with his office. Whether the language is also a definite expression of intention to limit impeachment to indictable crimes is not clear. "High crimes and misdemeanors" are the traditional words used to describe grounds for impeachment.27 And though it has often been argued that "misdemeanor" means an indictable crime, results in impeachment cases show the general rule to be otherwise. ${ }^{28}$ For instance, in Addison's Trial, before the Pennsylvania Senate, the defendant, a president judge of Common Pleas, was impeached for refusing to allow one of his associates to express an opinion

20. See Saar v. Hanlon, 163 Pa. Super. 143, 60 A.2d 432 (1948).

21. Pa. Constit. of 1874, ARt. VI, $\$ 3$.

22. E.g., State v. Mayes, 165 Tenn. 381,54 S.W.2d (1932). U.S. v. Am. Brewing Co., 296 F. 772, 776 (E.D. Pa. 1924). The term "civil" may have a restricted meaning in consequence of a special Constitutional provision. See Opinion of the Justices, 303 Mass. 615, 620, 21 N.E.2d 551, 555 (1939), where the court declared county commissioners to be "civil" officers, but not officers of the commonwealth for purposes of impeachment.

23. PA. CoNSTIT. of 1874, ART. VI, §§ 1-3.

24. See Ferguson v. Maddox, 114 Tex. 85, 263 S.W. 888 (1924).

803 (1938).

25. Dauph. Co. Grand Jury Invest. Proc. (No. 2), 332 Pa. 342, 345, 2 A.2d 802, 26. Ibid.

27. Simpson, A Treatise on Federal Impeachiments 35 (1916).

28. See Ferguson v. Maddox, 114 Tex. 85, 96, 263 S.W. 888, 892 (1924); Simpson, op. cit. supra note 27 at $36-49$. For the opposing view, see Dwight, Trial by Impeachment, 15 AM. L. REG. 257 (1867). The view of Prof. Dwight was rejected by the court in State v. Hastings, 37 Neb. 96, 114, 55 N.W. 774, 780 (1893). 
to a jury. The defendant argued that this was no indictable crime, but was found guilty and disqualified from future public office. ${ }^{29}$

Impeachment procedure may be effectively illustrated by contrast with the proceedings to which W. Frank Marshall was recently subject. Marshall was tried under a statutory provision entitled "impeachment," 30 but the proceedings were different from Constitutional impeachment. ${ }^{31}$ His trial was before Philadelphia's City Council. The statute requires the president judge of common pleas to preside at the trial, to rule on the admissibility of evidence, and to enter judgment declaring the office vacant should City Council convict. ${ }^{32}$ The statute does not authorize a judgment disqualifying a defendant from future public office. Thus, conviction under the statute could only result in removal from the term of office, and the ousted incumbent may be either reelected or reappointed to office.

Constitutional impeachment is a humiliating procedure carrying with it the teeth of a criminal sentence. But few of the safeguards we afford to criminal defendants are granted, nor is there appeal from such judgment. Therefore, every effort should be made to keep impeachment within reason. Some states adhere to a "judicial" view of impeachment.33 Proponents of this theory advocate an impeachment common law whereby a Senate is bound to impeachment precedents. ${ }^{34}$ Clearly this position is better than the "political" view which holds the trial body to no standards other than its enlightened conscience. ${ }^{35}$ By the latter theory anything that evidences unfitness to hold a public office or any moral delinquency may be sufficient grounds. As a consequence of "political" impeachment, the practice in Oklahoma may result. Impeachment is described by one jurist there as the favorite sport short of the open season on quail. ${ }^{36}$

Misbehavior in Office.-The Pennsylvania Constitution provides for the removal of all public officers if after indictment and trial, they are convicted of the common law crime of misbehavior in office. ${ }^{37}$ This is a removal device quite distinct from impeachment. ${ }^{38}$ No disqualification

29. Trial of Judge Addison, Duane's Select Panpmlets (1809).

30. Pa. Stat. AnN., tit. 53, $\$ 3001-7$ (Purdon 1931).

31. The differences were pointed out by the court construing an almost identical statute in In Re Impeachment of J. J. Sweeney (No. 2), 65 Pitts. L.J. 498 (Pa. C.P. 1917).

32. See the construction of the statute formulated in Marshall Impeachment case, $363 \mathrm{~Pa} .326,69$ A.2d 619 (1949).

33. Ethridge, The Law of Impeachment, 8 MIss. L.J. 283 (1936).

34. For the view that impeachment has a common law see Ferguson v. Maddox, 114 Tex. 85, 97, 263 S.W. 888, 892 (1924); 1 STORY ON CoNsTiT., \$\$797-8 (5th Ed. 1891).

35. Ethridge, supra note 33. (1930).

36. Lydick, Tyranry of Impeachment Procedure, 8 N.Y.U. L.Q. REv. 257, 267

37. Pa. Constit. of 1874, Art. VI, §4.

38. See Dauphin Co. Grand Jury Invest. Proc. (No. 2), 332 Pa. 346, 2 A.2d 304 (1938) where a statute purporting to suspend proceedings for misbehavior in office pending investigation for impeachment was held unconstitutional as an interference with judicial process. 
to hold public office in the future results. The offense may be committed in two ways: by the corrupt performance of a discretionary duty, or by the wilful disregard of a mandatory duty. ${ }^{39}$ In this connection the word "wilful" does not imply fraud; it is equivalent to "intentional." 40 Thus, it is sufficient if a jury specifically finds that school board members intentionally disregarded the mandatory duty of only purchasing school supplies through public bidding. ${ }^{41}$ The jury need not find in this case (as they would have to if the duty were discretionary), that a corrupt motive such as benefit to the school board existed. Further, it is essential for conviction of misbehavior in office that the offense be committed in the present, rather than a prior, term of office. ${ }^{42}$ Conviction constitutes a mandate that judgment of removal be entered. ${ }^{43}$

The misbehavior-in-office device has the merit of being the second furthest removed of the Constitutional provisions from politics. Automatic removal caused by conviction of an infamous crime appears to be still further removed since the activities leading to removal need have no connection whatsoever with the officer's official duties. On the other hand, removal through impeachment, at the address of the Governor and Assembly, and by the appointing officer are so closely interwoven with politics that it is difficult to conceive of a removal under any of these provisions which would not bear a political stigma. Such a political flavor is not likely to enter so violently into jury decisions which form the basis for removal under the misbehavior-in-office and infamous crime provisions. ${ }^{44}$

But removal for misbehavior in office has serious limitations. In Pennsylvania, "constitutional" officers may only be removed under a provision of the Pennsylvania Constitution. ${ }^{45}$ Therefore, unless some Constitutional provision other than misbehavior in office is invoked, removal of such officers cannot be accomplished for lesser causes than intentional disregard of a mandatory duty of the office. Many states allow removal for lesser causes; ${ }^{46}$ incompetence is often the gist of removal. ${ }^{47}$ And Pennsylvania's own statutes show a recognition of grounds for removal not amounting to wilful misconduct. The City Charter Act, for instance, under which Marshall was tried, authorizes removal for such causes, inter

39. See, e.g., Com. v. Hubbs, 137 Pa. Super. 244, 8 A.2d 618 (1939) ; Com. v. Brown, 116 Pa. Super. 1, 175 Atl. 748 (1934); Com. v. Kline, 107 Pa. Super. 594, 164 Atl. 124 (1933); Com. v. Miller, $94 \mathrm{~Pa}$. Super. 499 (1928); Com. v. Rosser, $102 \mathrm{~Pa}$. Super. 78, 156 Atl. 751 (1930).

40. See Com. v. Hubbs, 137 Pa. Super. 244, 8 A.2d 618 (1939).

41. Com. v. Zang, 142 Pa. Super. 566, 16 A.2d 741 (1940).

42. Com. v. Rudman, 56 D. \& C. 393 (Pa. C.P. 1946).

43. Com. v. Davis, 299 Pa. 276, 149 Atl. 176 (1930).

44. PA. Constit. of 1874, Art. VI., $\$ 4$.

45. See note 16 sipra.

46. For an excellent collection of illustrations from various jurisdictions see Ford, Administrative Removal of Public Officers, 30 B.U.L. REv. 520-529 (1950).

47. See, e.g., State v. Coleman, 115 Fla. 119, 155 So. 129 (1934); Riggins v. City of Waco. 100 Tex. 32, 90 S.W. 657 (1906). 
alia, as "mismanagement, mental incapacity, or incompetence for the proper performance of official duties." 48 Constitutional amendment is necessary to extend such provisions to cover all types of public officers.

By far the largest impediment to frequent use of removal for misbehavior in office lies in the fact that removal cannot be had for an offense committed in a prior term of office. ${ }^{49}$ If an offense is discovered during a second term of office, and the offense is not a breach of a continuing duty, one which should be performed in the second as well as the first term, proceedings under present law cannot be brought. If the offense is discovered toward the end of the first term, proceedings may be of no use other than to bring the alleged conduct into the public eye. Under present law the arrival of the end of the term would cause the proceedings to be discontinued in the absence of very special circumstances.

Among the various states there exists a decided split upon the question of whether a public officer may be removed for conduct committed during a prior term of office. ${ }^{50}$ Primarily, the question is whether removal has the purpose, despite a reelection, of ridding government of officers with undesirable qualities, ${ }^{51}$ or whether removal should be controlled by the vote of the electorate. ${ }^{52}$ Accordingly, the view that reelection is public condonation of misconduct in a prior term is opposed to the view that misconduct has rendered an officer wholly unfit to serve further. Within these two broad contentions lie some refinements. On the one hand, some jurisdictions have made exceptions to the "public condonation" view, and allow removal where it is plain upon the facts that the public knew nothing of previous misconduct. ${ }^{33}$ On the other hand, some jurisdictions hold tenaciously to the position that removal of an officer who has been reelected could not have been intended since each term of office is a "separate entity" for which removal alone is prescribed. ${ }^{54}$

Pennsylvania's leading case on this subject followed the majority view of 1929 and held removal for misconduct in a prior term to be impossible. ${ }^{55}$ The court's language seemed to indicate approval of the "separate entity" theory. ${ }^{58}$ The court, however, went on to say that evidence of acts occurring in a prior term might be independently relevant for the limited purpose

48. PA. Stat. ANN., tit. 53, \$3001 (Purdon 1931).

49. Fudula's Petition, 297 Pa. 364, 147 Atl. 67 (1929).

50. For the position that removal may not be had for misconduct in a prior term of office see, e.g., Advisory Opinion, 64 Fla. 168, 60 So. 337 (1912) ; Fudula's Petition, 297 Pa. 364, 147 Atl. 67 (1929) ; State v. Hasty, 184 Ala. 121, 63 So. 559 (1913). For the contrary position see, e.g., People v. Gill, 291 I11. App. 321, 9 N.E.2d 600 (1937) ; Becher v. Case, 243 App. Div. 375, 277 N.Y. Supp. 733 (2d Dept. 1935). See Ethridge, The Law of Impeachment, 8 Mrss. L.J. 283, 293 (1936).

51. See Opinion of the Justices 308 Mass. 619, 33 N.E.2d 275 (1941) ; Newman v. Strobel, 236 App. Div. 371, 258 N.Y. Supp. 402 (4th Dept. 1932).

52. See Kingfisher County v. Shutler, 139 Okla. 52, 281 Pac. 222 (1929).

53. See, e.g., Bolton v. Tully, 114 Conn. 290, 158 Atl. 805 (1932).

54. Thurston v. Clark, 107 Cal. 285, 40 Pac. 435 (1895).

55. Fudula's Petition, 297 Pa. 364, 147 Atl. 67 (1929).

56. Fudula's Petition, supra at 367, 147 Atl. at 68 (1929). 
of inquiring into motive and intent as to acts committed in the second term. ${ }^{57}$ Since 1929 the Pennsylvania Court has twice made reference to this decision. In 1930 the question arose in a removal case where proceedings had begun before a reelection of the officer. It was decided that proceedings should continue, despite the reelection, only because the court could not otherwise apply a statute directing disqualification to hold the office if judgment of removal were entered. ${ }^{58}$ The court pointed out that in the 1929 case proceedings had not begun during the prior term of office. In 1942 the Pennsylvania court held that the omission of a mandatory duty in a prior term of office will not be grounds for removal, but that same omission will constitute a dereliction of duty in the succeeding term, if the duty should have been performed in that second term. ${ }^{59}$

The "condonation" theory would appear to have merit where an official is reelected after his alleged misconduct has been fully aired. Here it may fairly be said the public has declared evidence of such previous conduct not to be controlling. That public opinion should be considered is plain from the fact that subsequent to trial an officer removed can be elected to the same office. But where the conduct is not discovered, the vote of the electorate can have no relevance. Under these circumstances, the rationale behind the "separate entity" theory, by which "it cannot have been intended" to remove a reelected officer, has no application.

Removal on Conviction of Infamous Crime.-The Pennsylvania Constitution also provides for the removal of all public officers upon conviction of an infamous crime. ${ }^{60}$ In 1842 the Pennsylvania Court defined infamous crimes to be those which would disqualify a witness at common law-"treason, felony (common law), and every species of the crimen falsi such as forgery, perjury, attaint of false verdict, and other offenses which involve the charge of falsehood and affect the public administration of justice." ${ }^{21}$ Whether this definition would be satisfactory to the present court in determining the necessity to remove an officer, is questionable. In the early case it was decided that a sheriff who had bribed a voter before election should not be removed. ${ }^{62}$ The court based its decision upon the ground that bribery of a voter was not infamous since it did not interfere with the administration of justice, whereas bribery of an official would be infamous, since there would be such an interference. It seems probable, however, that the impact of this decision is only that an offense must be committed during the term of office, and not before election, in order to justify removal. ${ }^{\text {B3 }}$

57. Id. at 368,147 Atl. at 68 .

58. Throop Borough School Directors Case, 298 Pa. 453, 148 Atl. 518 (1930).

59. Crane's Appeal, 344 Pa. 624, 26 A.2d 457 (1942).

60. PA. Constit. of 1874, ARt. VI, §4.

61. Com. v. Shaver, 3 W. \& S. 338, 342 (Pa. 1842).

62. Ibid.

63. Fudula's Petition, 297 Pa. 364, 368, 147 Atl. 67, 68 (1929). 
The offense of speeding an auto could not be said to require removal; murder clearly should. Between these offenses lies an unsettled area only clarified by the above-mentioned early definition. Would not a rule considering the extent of punishment, as well as the nature of a crime, more clearly express the modern concept of infamy? And should not conviction of an infamous crime always be a bar to public office?

\section{Removal Provistons Onty Applicable to Certain Public Officers}

Thus far three Constitutional removal provisions have been considered: Impeachment by the Legislature and removal for either misbehavior in office or the commission of an infamous crime. These are applicable to all public officers, state, county, or municipal, but they are not the only possible removal methods. We now turn to consider two other Constitutional provisions: elected officers, with certain exceptions, may be removed by the Governor at the address of two thirds of the Senate; appointed officers, with two exceptions, may be removed by the power which appointed them. ${ }^{84}$

Since public officers must be either appointed or elected, the position was soon taken that because the Constitution had specified in what manner elected and appointed officers should be removed, no other method was possible. Although such a doctrine was never thought to apply to employees, where public officers were concerned, it had the support of Pennsylvania courts until 1927. ${ }^{65}$ Since 1927 the doctrine has lost ground, but it is still successful as to "constitutional" officers and in cases where the Legislature has provided no other removal method. Where an officer is of the "constitutional" type, he must be removed under a Constitutional provision. ${ }^{66}$ If he is "non-constitutional" and the Legislature has provided a removal method, then the statute should be followed. ${ }^{67}$ But if the officer is "non-constitutional" and no removal law has been enacted, then an appropriate Constitutional provision again becomes controlling. ${ }^{68}$

Iust who are the "constitutional" officers that receive immunity from legislative removal plans? It was stated previously that they are people whose officers are provided for in the 1874 Constitution. In addition to a number of state officers, such as Governor, Lieutenant Governor, the Pennsylvania Constitution lists a large group of county officers varying from commissioners to surveyors. ${ }^{69}$ This group clearly comprises "constitutional" officers. Within the section listing county officers, provision is also made "for such other (county officers) as . . . may be provided

64. PA. Constit. of 1874, Arr. VI, §4.

65. Muir v. Madden, $286 \mathrm{~Pa} .233,133$ Atl. 226 (1926); Arthur v. Phila., 273

Pa. 419, 117 Atl. 269 (1922); Com. v. Hoyt, 254 Pa. 45, 98 At1. 782 (1916).

66. See note 16 supra.

67. See note 17 supra.

68. Com. v. Reid, $265 \mathrm{~Pa} .328,108$ Atl. 829 (1919); See Marshall Case, $360 \mathrm{~Pa}$. 304, 310, 62 A.2d 30, 33 (1948).

69. Pa. Constit. of 1874, Art. XIV, §1. 
by law." 70 Are county officers of this latter group, also "constitutional" officers with the result that they may not be removed except by a Constitutional removal provision? The Legislature has raised some city officers to county status by the authority of this Constitutional provision. The Enabling Act of 1876 provides: "In all cases where a city containing over three hundred thousand inhabitants is co-extensive in boundaries with the county, all the offices known therein as city treasurer, city commissioners, shall severally be regarded as county officers." 71 . This statute was obviously aimed toward officers of the City of Philadelphia, where the City and County are co-extensive in boundaries. Its purpose was to achieve a salary increase for holders of the specified offices. But the question of how to remove one of these officers may well arise. ${ }^{72}$ And it is equally possible that the Pennsylvania Legislature may wish to raise other city officers to county status or create other county officers.

It is arguable that these legislatively created county officers are not "constitutional" officers for removal purposes. At least the Pennsylvania Court's Construction of Article XII, Section I, of the Pennsylvania Constitution would suggest such a conclusion. This section gives the legislature power to provide for the election or appointment of officers other than those provided for in the Constitution. Since 1927 it has been construed to give incidental authority to provide for the removal of officers who are "the creature of the legislature," 73 i.e. non-constitutional officers. To the extent that a city officer is raised to county status by legislative enactment he would seem to be such a creature of the legislature. One would suppose that a legislature could repeal its own Enabling Act. ${ }^{74}$ But the lower court's dicta in the first Marshall Appeal is of a contrary opinion. Marshall argued that he could not be removed under a statutory removal provision for the reason that he had county-wide duties in Philadelphia and was thus a county officer, removable only under a Constitutional provision. In rejecting this contention the lower court said that county officers were those specified in the Constitution plus those "made constitutional" by the Enabling Act. ${ }^{75}$ Inasmuch as Marshall's office, Receiver of Taxes, was not mentioned in the Constitution or the Enabling Act, it was concluded he was not a "constitutional" officer. The Supreme Court affirmed this conclusion, but only referred to the Enabling Act's

70. Ibid.

71. PA. Stat. ANn. tit. 16, $\$ 2242$ (Purdon, 1931).

72. Two early cases decided that the offices of city controller and city treasurer in Phila. were county offices for the purposes of filling vacancies. Removal of the officers was not in issue. See Taggart v. Com., $102 \mathrm{~Pa} .354$ (1883) ; Com. v. Oellers, $140 \mathrm{~Pa}$. 457, 21 At1. 1085 (1891) (three dissenting opinions). The "City Commissioners" of Phila. are now county officers by specific constitutional amendment. PA. Constit., ARt. XVIII, § 33.

73. Milford Township Supervisors' Removal, 291 Pa. 46, 139 At1. 623 (1927); Weiss v. Ziegler, 327 Pa. 100, 193 Atl. 642 (1937) ; Marshall Impeachment Case, $360 \mathrm{~Pa} .304,62$ A.2d 30 (1948).

74. The early cases seem to hold otherwise. See note 72 supra.

75. Brief for Appellants, Marshall Case, pp. 16a-17a. 
failure to mention the office of Receiver of Taxes as being some historical evidence that the office is a municipal rather than a county position. ${ }^{\mathbf{7 6}}$

The list of officers enjoying Constitutional immunity from statutory removal is already too long. It might be advisable to spare state officers, particularly the prominent ones, from removal proceedings such as those to which Marshall was subjected. Those proceedings may be brought by any twenty voters and a judge. ${ }^{77}$ But county officers, often functioning along with municipal officers, should not be given disproportionate protection. What reason exists for making Philadelphia's sheriff immune from trial under the City Charter Act while her Receiver of Taxes enjoys no such immunity? Why should a backwoods Justice of the Peace be removable only in Harrisburg while a $\$ 15,000$ salaried Philadelphia officer be removable under local municipal procedure. It is urged that the list of officers immune from statutory removal should not be increased by any decision declaring county officers, made such by the Legislature, to be "constitutional" officers for removal purposes.

The Pennsylvania Court has recently made every effort to sustain statutory removal plans in their application to other than "constitutional" officers. Prior to 1927 the Court's position was exactly opposite. Until then legislation purporting to create removal methods different from the Constitution were held unconstitutional. ${ }^{78}$ For instance, the legislature could not restrict the power of an appointing officer to remove his appointee at will even though the officer was "non-constitutional." Further, it was unconstitutional for the legislature to annex the requirement of a hearing. The court, however, changed its position in 1927, when considering the legislature's power to provide for removal of an elected officer; it held the Constitutional provision "inapplicable, where the legislature, having the right to fix the length of a term of office, has made it determinable by judicial proceedings, on other contingencies than the mere passage of time." 79 And in 1937 the doctrine was definitely extended to legislative provisions for removal of appointed officers. ${ }^{80}$ The present law was summarized by the late Chief Justice Maxey in the first Marshall appeal where he wrote in approval of the above decisions: "We held that if an office is the creature of the legislature, the latter can establish a method for the incumbent's removal. The Office of Receiver of Taxes is an office created by the legislature." 81

In 1926 the following argument was made in favor of sustaining the applicability of a legislative removal provision to a non-constitutional officer: If the legislature had created both the office and the removal method

76. See Marshall Case, 360 Pa. 304, 307, 62 A.2d 30, 31 (1948).

77. Pa. Stat. AnN. tit. 53, §3002 (Purdon, 1931).

78. See note 68 supra.

79. Milford Township Supervisor's Removal, 291 Pa. 46, 52, 139 Atl. 623, 625 (1927).

80. Weiss v. Ziegler, 327 Pa. 100, 193 At1. 642 (1937).

81. Marshall Case, $360 \mathrm{~Pa}$ 304, 309-311, 62 A.2d 30, 33 (1948). 
prior to the Constitution of 1874, the Constitution is not to be regarded as abrogating the removal method, but rather as incorporating it. Therefore, a statute passed after 1874 which "substantially continues" the enactment prior to 1874 is a valid continuation of existing law. This argument was accepted, ${ }^{82}$ and the position was affirmed by the Pennsylvania Court in the Marshall case. ${ }^{83}$ So far it has been held that where a later statute merely gives a different court the same power to remove an officer, there is such a "substantial" continuation. ${ }^{84}$ Apropos of Marshall's case, the pre-Constitutional Act of 1854 , provided for complaint by the common council and trial by the select council. ${ }^{85}$ Marshall argued that the City Charter Act is substantially different in that while formerly the common council preferred the charges, it is now only necessary for twenty voters to start the machinery rolling. ${ }^{86}$ The Pennsylvania Court did not accept the argument, and held the City Charter Act provision to be substantially similar. ${ }^{87}$

It is abundantly clear that the Pennsylvania Court will sustain legislative removal plans as to "non-constitutional" officers. Under present law, however, statutory removal cannot reach "constitutional" officers. It is urged that "home-rule" government is not advanced by inconsistency of treatment for equally important public officers. The fact that the Supreme Court of Pennsylvania was able to reverse its conclusion as to legislative removal of "non constitutional" officers gives us reason to think that there may be a new delineation of "constitutional" officers in the future.

However, a present court's willingness cannot provide effective relief when faced with a long line of authority to the contrary. Lengthy litigation over the classification of a particular public servant may be deplored, but no change in result will occur if a person is finally determined to have "constitutional" status. Courts may strain to find a pre-constitutional removal method being "substantially" continued by a post-constitutional removal statute, but such a doctrine is of limited application. And its very complexity urges the abolition of any need for it. Constitutional revision is the only complete answer.

\section{SumMary}

Five removal provisions of Pennsylvania's Constitution have been discussed with an eye toward their inadequacies. Impeachment is open to abuse in that limitations are relatively few and undefined. Misbehavior in office will not accomplish removal of many officers for less than inten-

82. Georges Tp. School Directors, 286 Pa. 129, 133 Atl. 223 (1926).

83. 360 Pa. 304, 62 A.2d 30 (1948).

84. Georges Tp. School Directors, 286 Pa. 129, 133 Atl. 223 (1926).

85. AcT of 1854 , P.L. $21, \S 45$.

86. Brief for Appellants, Marshall Case, pp. 16-17.

87. See note 76 supra. 
tional misconduct. Incompetency, insanity, alcoholism, should also be cause for their removal. Under neither the misbehavior-in-office device nor the removal which is directed for commission of an infamous crime can an officer be ousted for offenses committed in a prior term. Further, as to some officers, legislatively prescribed removal will be applicable; as to others, it will not. It is clear that the Legislature is virtually powerless with respect to county officers.

Inasmuch as the Pennsylvania Bar Association, through its Committee on the Pennsylvania Constitution, is considering Constitutional revision at this date, it is particularly appropriate to direct our attention to the removal provisions of the Constitution. The following recommendations are offered:

a) Retention of impeachment as it now exists with two qualifications: (1) that the Senate must follow impeachment precedents, and (2) that a direct appeal to the Pennsylvania Supreme Court will lie upon the question whether or not an impeachable offense has been committed.

b) Removal of all officers convicted of an offense for which imprisonment for two years or more could have been imposed; this to be effected whether or not the offense was committed in connection with the duties of the office and whether or not committed prior to or during a term of office. Two years is selected as the measure so as to exclude minor offenses punishable under such statutes as the Motor Vehicle Code.

c) Retention of removal for misbehavior-in-office, but expanded to include as an offense incompetency and the mental or physical inability to properly serve. Also provision should be made for removal in cases where the offense, other than such mental or physical inability, occurred in a prior term of office and was not disclosed to the public at the time of reelection. This recommendation would retain indictment and trial by jury in cases where removal for incompetency, insanity or alcoholism is sought. It seems preferable that such procedure be used rather than place such a determination in the hands of administrative officials who might find it to their advantage not to bring action. The Attorney General can force an indictment, ${ }^{88}$ and thereafter politics will be less prominent.

d) The limitation to State officials of the right to be removed only by a Constitutional method. Such an amendment would permit legislatively prescribed removal of county officers, but at the same time permit removal under the Constitution in the absence of legislative provision.

88. Appeal of Margiotti, 365 Pa. 330, 75 A.2d 465 (1950). 
e) Retention of the right of appointing powers to remove at will their appointees with the exceptions as now provided. It appears proper to preserve the right of an appointing power to remove his appointee at will in cases where the legislature does not see fit to restrict such right.

f) Abolition of the right of the Governor to remove elected officers at the address of two-thirds of the Senate. In accordance with the policy in favor of locally operated removal methods supplied by the Legislature it would seem wise to withdraw this provision. Elected state officials could still be reached through the misbehavior-in-office device.

\section{Home Rule Taxation and the Pennsylvania Courts}

Three years have now passed since Pennsylvania entered upon its bold experiment of allowing local government to support itself by levying its own taxes. The Pennsylvania Home Rule Taxation Law, Act $481,{ }^{1}$ represented an important rebellion against state handouts and grants in aid to local government and brought hopes of a new era of local responsibility.

The exuberance of local tax officials "baying on the trail of new tax sources with the eagerness of the bloodhounds pursuing Eliza across the ice" 2 has now somewhat abated. Herein are chronicled the limitations which have been judicially imposed upon the statutory grant to local governments.

Essentially the Act is a simple delegation of the State's taxing power to the various units of local government. It has been held to be a valid delegation. $^{3}$ It was preceded by the Sterling Act of 1932 which granted to the City of Philadelphia power to tax everything not taxed by the state. ${ }^{4}$ Act 481 extended the principle of Home Rule Taxation to all of the other cities, boroughs, and school districts of the Commonwealth, as well as to the urban townships. ${ }^{5}$ Few states have enacted similar enabling legislative grants. ${ }^{\mathbf{B}}$

1. PA. Stat. ANn., tit. 53, $\$ 2015.1$ (Purdon, Supp. 1949).

2. Burkhead, Permissive Lacal Taxation in Pennsylvania, 1948 Proc. Nat. TAX Asso. 12, 19 quoting Phila. Inquirer, July 19, 1948.

3. English v. Robinson Township School District, 358 Pa. 45, 49, 55 A.2d 803 (1947).

4. PA. Stat. Ann., tit. 53, $\$ 4613$ (Purdon, Supp. 1949).

5. Townships of the second class are not covered by the act. They are townships of less than 300 people per square mile. See PA. STAt. ANN., tit. 53, \& 19093-201 (Purdon, Supp. 1949).

6. Ohio has discovered such power in its general constitutional home rule provision. See Fordham and Mallison, Local Income Taxation, 11 OHIo St. L.J. 217 (1950). 
Of course a disinterested desire for local responsibility was not the only motive behind Act 481 . The plain fact was that Pennsylvania was nearing its wits end in the search of revenue. ${ }^{7}$ Kelley $v$. Kalodner, ${ }^{8}$ which declared that a graduated income tax violates the uniformity clause of the constitution, killed any practical chance for an effective income tax and the legislature was unwilling to impose a sales tax on the electorate. Thus Pennsylvania, as one of the few states with neither of these basic sources of tax revenue, ${ }^{9}$ was forced to resort to a multitude of miscellaneous taxes, as well as imposing heavy taxes on its corporations, ${ }^{10}$ especially the socalled captive industries, such as coal, which are in a peculiarly vulnerable position. It was believed that it would be wise to leave the imposition of these miscellaneous taxes to the discretion of local officials who would know where the strain could best be taken. Of course, this incidentally has the effect of taking the unpopular tax spotlight off the legislature. There is also much to be said for the argument that a tax is more palatable when it is levied on the taxpayers who will receive its benefits, rather than going through the mechanisms of state government to furnish services hundreds of miles away.

\section{Persons, Transactions, Subjects, Occupations and Privileges Taxed by the State}

Aside from the limitations engrafted on the local units by the Act itself, Pennsylvania also has a constitutional requirement of uniformity. ${ }^{11}$ This requires that any classification must be reasonable and that taxation within the class must be uniform. While the local tax unit must, almost of necessity, be the geographical area selected, ${ }^{12}$ still lack of uniformity may be found by reason of exceptions granted or by choosing a classification which the court finds is unreasonable. ${ }^{13}$ Thus it has been held unrea-

7. Low tax revenues had so retarded expenditures that by 1948 Pennsylvania was $43 \mathrm{rd}$ among all of the states in money spent per capita. TAx Polrcy, Sept. $1949,6$.

8. 320 Pa. 180, 181 Atl. 598 (1935).

9. 34 states have income taxes and 27 have sales taxes. Co-ordination of Federal, State, and Local Taxation, 266 Annals 144.

10. Corporations paid more than one half of the taxes flowing into Harrisburg in the biennium 1943-45. The corporate net income tax supplied 30.3\% of the state's revenue, the capital stock and franchise taxes, $14.5 \%$, gross premium taxes (insurance companies) $3.96 \%$, and the state banking tax $2.86 \%$. Proposals for Revision of the Tat Structure of the Commonwealth of Pennsylvania, Report \#11 of the Tax Advisory Comm. (1945).

11. PA. Const., Art. IX, $\S 1$.

12. Moore v. Pittsburgh School District, 338 Pa. 466, 13 A.2d 29 (1940) settled that school boards of the same class may tax at different rates without infringing upon the constitutional restrictions.

13. Blauner's v. Philadelphia, 330 Pa. 342, 198 Atl. 889 (1938) declared invalid a provision exempting sales of under one dollar from the city sales tax. Smedley, Legal Problems Involving Act 481 (Pa. Bur. Mun. Affairs 1948) questions, for example, the validity of one borough ordinance which exempts clergymen from a per capita tax. 
sonable to tax coal by the ton and ignore the difference in dollar value among classes of coal. ${ }^{14}$

The basic exclusion from the Home Rule Taxation Act as passed in 1947 was that localities may not tax "persons, transactions, subjects, occupations and privileges" taxed by the state. ${ }^{15}$ While this exclusion might, at first glance, appear to be relatively simple, the Supreme Court has been called upon to develop an entire field of law in defining property taxed by the state.

By adopting the principle that a tax on income is a tax on its source ${ }^{16}$ the court did no more than follow a principle which Pennsylvania law had adopted in Kelley $v$. Kalodner in 1935. ${ }^{17}$ That decision, which declared a graduated income tax unconstitutional under the uniformity clause, ${ }^{18}$ was made after a thorough consideration of the divergent points of view as represented on the one side by Pollock $v$. Farmers Loan and Trust Co. ${ }^{18}$ and state court decisions following its view ${ }^{20}$ and the contrary state court decisions that an income tax does not duplicate a property tax. ${ }^{21}$ The underlying problem in cases such as these is whether the court is going to look where the ultimate burden falls or is simply going to see whether the same "transaction" is taxed twice. The following example ${ }^{22}$ will illustrate how taxes can eventually fall on the same property and yet not constitute "double taxation" by strict tests.

"A tax is hereby imposed upon the privilege of conducting a retail grocery business in $\mathrm{X}$ township at the rate of $1 \%$ of gross receipts." This would appear to be a privilege (excise) tax.

"A tax is hereby imposed upon all retail grocery stores in $\mathrm{X}$ township at the rate of $1 \%$ of the sales of such stores." This sounds like a real estate tax.

14. Lawrence Township School Dist. Tax Case, 362 Pa. 377, 383, 67 A.2d 372 (1949).

15. There are three exclusions listed. See text at note 75 infra.

16. "But if a man seised of lands in fee by his deed granteth to another the profit of those lands. . . the whole land itself doth passe; for what is land but the profits thereof. . " Co. Lir. 4b. quoted with approval in Murray v. Philadelphia, 364 Pa. 157, 17i, 71 A.2d 280 (1950).

17. 320 Pa. 180, 181 Atl. 598 (1935).

18. The entire tax was struck down despite the severability provisions of the statute on the ground that the parts were so mutually dependent as to warrant a belief that the legislature intended them as a whole. The court said, "We pass no opinion upon the question of whether a tax upon the income from trades, occupations or professions is a tax on property, although respectable judicial opinion has indicated that it is not." Kelley v. Kalodner, 320 Pa. 187, 181 Atl. 598 (1935).

19. 157 U.S. 429 , rehearing, 158 U.S. 601 (1895).

20. State v. Pinder, 7 Boyce (30 Del.) 416, 108 Atl. 43 (1919); Bachrach v. Nelson, 349 I11. 579,182 N.E. 909 (1932); Opinion of the Justices, 220 Mass. 613, 108 N.E. 570 (1915); Culliton v. Chase, 174 Wash. 363, 25 P.2d 81 (1933).

21. Simms v. Aherns, 167 Ark. 557, 271 S.W. 720 (1925); Diefendorf v. Gallet, 51 Idaho 619, 10 P.2d 307 (1932); Miles v. Dept. of Treasury, 209 Ind. 172, 193 N.E. 855 (1935); Ludlow-Saylor Wire Co. v. Wollbrinck, 275 Mo. 339, 205 S.W. 196 (1918).

22. The examples are quoted from Moore, The Home Rule Tast Act-A Solntion or a Challenge?, 97 U. of PA. L. REv. 811, 822 (1949). 
"A tax is hereby imposed upon all groceries sold at retail in X township at the rate of $1 \%$ of sales." This could be construed as a personal property tax.

"A tax of $1 \%$ is hereby imposed on all sales of groceries at retail in X township." This is probably a sales tax.

"A tax is hereby imposed upon all persons conducting a retail grocery business in $\mathrm{X}$ township at the rate of $1 \%$ of sales." This is a tax on persons.

"A tax of $1 \%$ is hereby imposed upon the profits of all retail grocery stores in X township." This is an income tax.

In Pollock v. Farmer's Loan ${ }^{23}$ the United States Supreme Court declared the federal income tax to be an unconstitutional direct tax on the ground that, as to income from property, it was essentially a tax on property. Since this left the Federal Government without adequate sources of revenue, the 16th amendment was passed in 1913 to undo the decision. However it does not follow from the ignominious history of the Pollock case that a court should hesitate to follow its logical, albeit unwise in context, approach. The problem of the Federal Government was essentially different in that it must find some means of reaching the great source of wealth represented in tangible property and the income from it. The court's decision denominating this kind of income to be so essential a characteristic of the income producing asset as to render the income identical with the property meant that as "property" it was beyond the reach of the Federal government. However the states face no such problem in that they possess a plenary power to tax whether it be found that they are reaching property directly or by indirection. A decision by a state court that income is property does not, of itself, deprive the state of any source of revenue. It merely forces the state to acknowledge that it is ultimately burdening the underlying property with two taxes. This in turn would create constitutional difficulties only in states which prohibit double taxation. ${ }^{24}$ A state faced with such a rule would be forced either to choose income from property or assessed valuation as the desirable tax base or else to abandon the burden theory in favor of a theory which will allow the use of both measures in order to reap a maximum return.

Whenever the burden theory is used to strike down double taxation it has a weakness in ultimate result insofar as it looks not to the way in which conflicting taxes are consonant with ability to pay but merely at whether there is a duplication in ultimate burden, justified or not. Thus as applied to the Pennsylvania situation, any man who is fortunate enough to be paying a slight state tax finds himself protected from local exactions, no matter how reasonable. Also the existence of one flat rate tax may

23. 157 U.S. 429, rehearing, 158 U.S. 601 (1895).

24. Pennsylvania has no constitutional prohibition against double taxation. However, Pennsylvania does require uniformity. PA. Const. Art. IX, §1. Cooley states that uniformity cannot exist where there is double taxation. This assumes that the second tax taxes some, but not all, of the property subject to the first tax. 1 COOLEY, TAXatTon 483 (4th ed. 1924). 
prevent the exaction of a more scientific graduated rate tax which could raise much more revenue from the same underlying source.

However, the Supreme Court seems to have adopted the economic burden theory with all of its infirmities for the reason that it has been patently clear in Pennsylvania that those who are being taxed by the Commonwealth are, in general, bearing as heavy a burden as it would be wise to impose on them ${ }^{25}$ while great segments of the economy have been completely free of state taxes. ${ }^{26}$ In this context all of the arguments that different measures strike differently and are justified in a side by side existence fail to fit the local situation and it is much more reasonable to say that the Act's prohibition against duplication of state taxes meant duplication of burden.

While all of the decisions, except the upholding of the mercantile license tax, are consistent with the economic burden theory the court has never actually enunciated such a doctrine by name. It has approached the question purely in terms of whether "property" is being taxed twice, but its concept of what constitutes double taxation of the same property can be fairly said to be an economic burden test. Even with the adoption of this concept the Supreme Court has encountered many difficulties in determining whether a tax does fall on property and whether taxes do burden the same subject. All of the taxes levied under Act 481 have to face this test. Nearly all of the problems which have arisen have been due to alleged conflict with one or more of the following state taxes: ${ }^{27}$

(1) The Corporate Net Income Tax ${ }^{28}$ - This tax, paid by all corporations, ${ }^{29}$ has uniformly been held to be a property tax in questions concerning double taxation, ${ }^{30}$ though there is a scattering of decisions referring to it as a privilege tax. ${ }^{31}$ Most of these decisions can be explained by the fact that the tax could not properly be termed a property tax when applied to non-resident corporations since the underlying property of such corporations would be beyond the taxing power of the Commonwealth.

(2) Capital Stock $\operatorname{Tax}^{32}$ - This tax, paid only by domestic corporations, is measured by the "actual value of the corporation's capital stock." "It is established by a multitude of decisions that a tax on the capital

25. See note 10, supra.

26. See text at note 9, supra.

27. Except the tax on rental income discussed in text at note 67 , infra.

28. Pa. Stat. AnN., tit. 72, §3420 (Purdon, 1949).

29. Except banks, insurance companies, building and loans, etc. which are covered by specific laws.

30. Philadelphia v. Samuels, 338 Pa. 321, 326, 12 A.2d 79 (1940); Blauner's v. Philadelphia, $330 \mathrm{~Pa} .342,345,198$ Atl. 889 (1938). In Federal Drug Co. v. Pittsburgh, $358 \mathrm{~Pa} .454,456,57$ A.2d 849 (1948) the court said, "Whether the Corporate Net Income Tax is regarded as a property tax or an excise tax, the tax was imposed upon property."

31. Commonwealth v. Electrolux Corp., $362 \mathrm{~Pa}$. 333, 67 A.2d 105 (1949);

Commonwealth v. Warner Bros., 345 Pa. 270, 27 A.2d 62 (1942).

32. Pa. Stat. Ann., tit. 72, §1871 (Purdon, 1949). 
stock of a corporation is a tax on all of its property and assets." 33 Actually any such "actual value" measure must mirror to a considerable extent the earning power of the corporation.

(3) Franchise $\operatorname{Tax}^{34}$-This tax is on foreign corporations only. It is levied on the proportion of the company's property used for doing business in Pennsylvania. Unlike the Capital Stock Tax it has been established to be a "privilege tax", 35 that is, a charge for a privilege (or tax on the exercise of a privilege) which is merely measured by the corporate property, not levied on that property itself. However, even this tax has been held to be so closely analogous to the Capital Stock tax for some purposes as to be essentially on property. ${ }^{36}$

Thus it can be seen that the Commonwealth levies at least two taxes on every corporation doing business in Pennsylvania ${ }^{37}$ and, though the labels differ, one is measured by income and the other by asset values. ${ }^{38}$ Faced with this situation, local taxes on corporations have not fared well in overcoming the statutory prohibition against double taxation.

The results are as follows:

(1) Local tax on specific corporate property-In Dick Contracting Co. v. Hazle Township School District ${ }^{39}$ a unanimous court held that the imposition of a tax on "strip mining equipment" conflicted with the state's corporate taxes which are to be treated as being levied on the corporate property. 40

(2) Local tax on the privilege of using specific corporate propertyThe court found that a tax on "the privilege of mining coal" conflicted with Act 481's interdict against taxes "on the privilege of employing such tangible property as is . . . subject to a state tax." ${ }^{41}$ This result

33. Lawrence Township School Dist. Tax Case, 362 Pa. 377, 381, 67 A.2d 85 (1949).

34. Pa. Stat. ANN., tit. 72, §1871b (Purdon, 1949).

35. Commonwealth v. Shenango Furnace Co., 362 Pa. 491, 67 A.2d 113 (1949); Commonwealth v. Ford Motor Co., 350 Pa. 236, 240, 38 A.2d 329, appeal dismissed, 324 U.S. 827 (1944).

36. Commonwealth v. Columbia Gas \& Electric Corp., 336 Pa. 209, 8 A.2d 404 (1939); Arrott's Estate, 322 Pa. 367, 185 Atl. 697 (1936).

37. Except for the corporations mentioned in note 29. Several of these corporations are specifically exempted from local taxation by earlier laws. See PA. STAt. AnN., tit. 72, \$1961 (Purdon, 1949) (banks); PA. STAT. ANN., tit. 72, §1991 and 2011 (Purdon, 1949) (trust companies). Savings Funds were held exempt because they pay a tax on net earnings. PA. Stat. ANn., tit. 72, §2241 (Purdon, 1949).

38. Many corporations also pay other state taxes such as license fees for specific businesses or the corporate loans tax.

39. 362 Pa. 387, 65 A.2d 381 (1949).

40. Other cases holding taxes on specific corporate property invalid include Jamison Coal and Coke Co. v. Unity Township School Dist., 362 Pa. 389, 66 A.2d 759 (1949) ("coal mined"); Lawrence Township School Dist. Case, 362 Pa. 377, 67 A.2d 372 (1949) ("coal mined"); Peoples Natural Gas Co. v. Pittsburgh, 317 Pa. 1, 175 Atl. 691 (1934) (gas meters).

41. Hampton Township School District Case, 362 Pa. 395, 67 A.2d 376 (1949). Dissenting opinion on the basis of Federal Drug Co. v. Pittsburgh, $358 \mathrm{~Pa}$. 454, 
was reached by reasoning similar to that used in the Dick Contracting case. ${ }^{42}$ This section of Act 481 has been considerably strengthened by the 1949 amendments. ${ }^{43}$

(3) Local taxes on corporate net income-Attempts to tax corporate income have fallen on the same basic ground. ${ }^{44}$ Here the court has continued its practice of looking through both the state and the local income taxes and has thereby found that each is a tax on the corporate property and that thus the property itself is being subjected to double taxation. It would seem that this tax could just as well have been stricken down on the ground that it is the income itself which is being subjected to two taxes.

(4) Mercantile License Taxes-The one attempt at reaching corporations which has been allowed is the mercantile license tax. ${ }^{45}$ While it is true that this tax is not limited to corporations, the presence or absence of discrimination against corporations has not been considered a relevant factor in determining the legality of taxes passed under Act $481 .{ }^{46}$ A mercantile license tax is generally measured by the gross volume of business done and is thus far less scientific than an income tax in that it has no relation to profits made. Technically such taxes are only measured by gross income, and are on the privilege of conducting business, not on

57 A.2d 849 (1948) which had upheld a mercantile license tax on the privilege of doing business. The court completely ignored Dunkard Township School Tax Case, $359 \mathrm{~Pa} .605,60 \AA .2 \mathrm{~d} 39$ (1948) which had upheld a tax "upon the privilege, transaction or occupation of mining, processing, and marketing coal." The Hampton tax was "upon the privilege . . . of bringing to the surface of the ground coal. . .." Evidently the Dunkard case is overruled.

42. However the court hedged somewhat on this logic in its opinion on reargument of the Lawrence Township School Dist. Case., 362 Pa. 386, 67 A.2d 372 (1949). "We are asked to reconsider our decision that the tax imposed . . . is a property rather than an excise tax. . . We deem it unnecessary to review the grounds upon which that decision was based in view of the fact that . . . even if such a tax $b e$ an excise and not a property tax, it is invalid because in violation of the prohibition in the statute against the local body imposing a tax on the privilege of employing property which is already taxed by the State." Thus the court recognizes that the Act forbids not only duplication of taxes (i.e. the same property being subjected to two property taxes), but also certain other forms of double burden which are not "double taxation" in the strict sense.

43. The 1949 amendments, passed one month before the Hampton opinion, prohibited taxation of "any privilege, act or transaction related to the business of manufacturing, the production, preparation or processing of minerals. . ." Taxation of privileges connected with public utilities was also prohibited. These amendments made one important change in that such taxation was forbidden whether the taxpayer was a corporation or not.

44. Murray v. Philadelphia, $364 \mathrm{~Pa} .157,71$ A.2d 280 (1950).

45. Federal Drug Co. v. Pittsburgh, $358 \mathrm{~Pa} .454,57$ A.2d 849 (1948) settled the validity of such taxes. It relied heavily on Blauner's v. Philadelphia, $330 \mathrm{~Pa}$. 342 , 198 Atl. 889 (1938) which held that there was not even duplication between a mercantile license tax and a sales tax, even though the measure was the same. See also Philadelphia v. Samuels, $338 \mathrm{~Pa}$. 321, 12 A.2d 79 (1940). The school districts of Philadelphia and Pittsburgh are specifically authorized to levy a mercantile license tax. PA. Stat. AnN., tit. 24, §582.2 (Purdon, 1950).

46. All of the severance taxes which have been struck down as to corporations were levied on all mining operations whether corporate or not. In the Murray case it was an attempt to establish uniformity in local taxation between unincorporated business previously taxed and corporations which was struck down. See text at note 63 infra. 
the income itself. ${ }^{47}$ If such reasoning is valid it is difficult to conceive why a corporate income tax could not be worded so as to have the same effect, yet at first glance the arguments that such taxes do differ from the state taxes are convincing. It is claimed that the locality could just as well levy a flat rate tax on this privilege and would not be taxing corporate income or property. However, a conflict with the Corporate Net Income tax can be found even here, since insofar as the locality is attempting to tax the producing value, as opposed to the physical asset value, of corporate property it is reaching for the same kind of value as the state is taking by its income tax. If the tax is defended as being on the general privilege of using property, instead of as on the local productive value of the property, then the situation is practically indistinguishable in principle from the Hampton case. ${ }^{48}$ There the court stated "A tax on the privilege of employing property is, from a practical standpoint, the same in effect as a tax upon the property itself, and . . . if permitted would be merely a substitute for a direct tax on the property." If that is true, and the Capital Stock tax is on the corporate property generally, then it is difficult to see why there is no conflict. Essentially the same thing is true as to the Franchise Tax though the argument is even stronger there since the court has specifically referred to such taxes as being on the privilege of using the corporation's property in Pennsylvania.48

A probable explanation of why the court upheld the mercantile license tax would be its great similarity to the Sales Tax which had been upheld in the Blauner's and Samuels cases. ${ }^{50}$ However, there is the distinction that a sales tax is imposed on the purchaser, while the license tax is paid by the seller and is supposedly not on the sale at all, but rather on the privilege of doing business. The fact remains that the mercantile license tax is on the business and that it has happened thus far to be measured so that it can easily be passed on to the public does not seem to be relevant as to its validity.

(5) Taxation of dividend income-The $M$ urray ${ }^{51}$ case also held that it was obnoxious double taxation to tax dividend income on the ground that such income was already reached by the taxes on the corporation's own property. The court's analysis here was that the shareholder has an

47. Federal Drug Co. v. Pittsburgh, $358 \mathrm{~Pa} .454,57$ A.2d 849 (1948) ; Blauner's. v. Philadelphia, $330 \mathrm{~Pa}$. 342, 198 Atl. 889 (1938). For a short discussion of the court's decisions looking to duplication of subject, rather than duplication of measure, as the test under Act 481 see Editorial Comment on the Power of Local Taxing Districts to Adopt Mercantile License Taxes, $3 \mathrm{CCH}$ PA. State TAX ReP. 10,266. (1949).

48. Hampton Township School District Tax Case, 362 Pa. 395, 67 A.2d 376

49. See note 35 , supra.

50. Blauner's v. Philadelphia, $330 \mathrm{~Pa}$. 342, 198 At1. 889 (1938); Philadelphia v. Samuels, $338 \mathrm{~Pa}$. 321, 12 A.2d 79 (1940). The city could not call its tax a mercantile license tax at that time since the state was then levying such a tax. Act of May 2, 1899, P.L. 184 as amended, PA. STAT. ANN., tit. 72, \$2621, repealed by Act of May 7, 1943, P.L. 237, PA. Stat. ANN., tit. 72, \$ 2621 (Purdon, 1949).

51. Murray v. Philadelphia, 364 Pa. 157, 71 A.2d 280 (1950). 
equitable or beneficial interest in the property represented by the shares of stock and that it is his property which is reached by the corporate taxes, and since'a tax on income is a tax on its source, a tax on his dividend income which is from the corporate property represents a duplicate tax on that property. Even with the court's general approach in tearing through fictions and differences in nomenclature which represent no substantial difference in fact, still this ripping of the corporate veil seems to go to an extreme. Admitting that the court may properly look at the substance of a tax and decide that while the measure is different the substance taxed is the same, ${ }^{52}$ it seems in the case of dividends in the hands of individual shareholders that even the substance is different ${ }^{53}$ and only by the most technical reasoning can we find the same thing being taxed twice. Of course, the argument has long been made in the federal tax field that there is an injustice in this kind of double taxation, but even the proponents of that argument do not advocate going to the extreme of considering the shareholders and the corporation as one. ${ }^{54}$ To deny reality to the fiction of the corporate entity in this manner would hardly accord with popular conceptions. Aside from this there is also a legal doctrine that one who chooses to take the advantages of dealing in the corporate form cannot ask that the corporate entity be ignored for his own benefit. ${ }^{55}$

(6) Sales and Admissions Taxes-No sales taxes have been levied under Act $481^{56}$ although such taxes were early upheld under the Sterling Act ${ }^{57}$ and no doubt would still be valid, since they are levied on the purchaser, not on the corporate seller. Admissions taxes stand on the same ground. ${ }^{58}$ The fact that the purveyor of a commodity pays taxes on his property and income should not bar collection from his customers.

52. "The practical operation of the two taxes is controlling as against a mere difference in terminology from time to time employed in describing taxes in various cases." Murray v. Philadelphia, 364 Pa. 157, 71 A.2d 280 (1950).

53. "The owner of the shares of stock in a company is not the owner of the corporation's property. He has a right to share in the earnings of the corporation, as they may be declared in dividends, arising from the use of all its property." Rhode Island Hospital Trust Co. v. Doughton, 270 U.S. 69 (1925).

54. See book review on the symposium published by the Tax Institute, How Should Corporations be Taxed?, 3 Tax L. Rev. 263 (1948).

55. Vim Securities Corp. v. Comm'r. of Int. Rev., 130 F.2d 106 (2d Cir. 1942), Carozza v. Fed. Finance \& Credit Co., 149 Md. 223, 131 Atl. 332 (1925).

56. With the possible exception of a tax in one community on "Cars Sold." By comparison, 184 communities have levied amusement taxes, 185 have levied wage taxes, 288 have per capita taxes and 181 had the now illegal severance taxes, 93 have taxed mechanical amusement devices and 39 ( 22 of them cities) have mercantile license taxes. Act 481: Its First Two Years of Operatton (Penna. Bureau of Municipal Affairs, 1949).

57. Blauner's v. Philadelphia, $330 \mathrm{~Pa}$. 342, 198 Atl. 889 (1938).

58. For a discussion of problems arising from amusement taxes, especially the exemptions often granted from such taxes see Smedley, Report on Legal Problems Involving Act 481 (Pa. Bur. of Municipal Affairs 1948).

Though amusement taxes have been levied under both the Sterling Act and Act 481, the court was never called on to pass upon their validity until Wilkinsburg Borough v. Wilkinsburg Borough School District, 365 Pa. 254, 74 A.2d 138 (1950). 
(7) Mechanical Devices Owned by Corporations-The status of these taxes is unsettled. Though they are quite common, no case involving such a tax has yet reached the Supreme Court. They are of very dubious validity however, since they appear to be either on corporate property or at least on the privilege of using such property. ${ }^{59}$

(8) Wage Taxes-Since the state levies no taxes on individuals (except minor excises such as those on cigarettes and soft drinks) these taxes are clearly valid ${ }^{60}$ and have become the major source of revenue under the Act. ${ }^{61}$ While it may come as a shock to proponents of economic democracy to see all income exempted from local taxation except the earned income of individuals and unincorporated business, ${ }^{62}$ state pre-emption requires that result and no economic injustice seems to have been worked.

Since neither the uniformity clause of the Pennsylvania Constitution nor the equal protection clause of the Federal Constitution require that corporations and individuals be treated alike for purposes of taxation where a reasonable basis for distinction exists, there seems to be no Constitutional violation involved in imposing on non-corporate enterprises the taxes which have been held invalid as to corporations. ${ }^{63}$ Thus localities may impose taxes upon non-real property of such businesses and upon the privilege of using such property. ${ }^{64}$ No question has yet arisen as to severance or other taxes on the privilege of using real property as applied to

59. See note 40, supra. See also Folcroft v. General Outdoor Advt. Co., 31 Del. Co. 292 (1950), holding that a tax on billboards owned by a corporation violates the prohibition of the Act.

60. Dole v. Philadelphia, $337 \mathrm{~Pa} .375,11$ A.2d 163 (1940); Butcher v. Philadelphia, $333 \mathrm{~Pa}$. 497, 6 A.2d 298 (1938).

61. 185 communities use this device. See note 56 supra. Wage taxes account for $30 \%$ of the revenue of the city of Philadelphia. Phila. Evening Bulletin, Dec. 5,1950 , p. 3 , col. 1 .

62. For a history of the Philadelphia Wage Tax Ordinance see Robinson, Changes Effected by Recent City Income Tax Ordinance, 3 CCH PA. STATE TAx REP. 10,617.

63. Quaker City Cab Co. v. Pennsylvania, 277 U.S. 389 (1928) held that it is a denial of equal protection to impose taxes on corporations in a given business which were not imposed on their non-corporate competitors, where no basis for distinction existed other than their form of organization. However this case could easily be distinguished since the basis of local government classification between corporations and non-corporate enterprises would be that the corporations have already been held to be paying substantially equivalent state taxes. The present Pennsylvania situation as to local taxes is unique in that it is non-corporate enterprise which will claim that it is being denied equal protection. Actually there is very little past experience or authority in regard to a taxation scheme which exempts corporations from general taxes. The court has never held that the corporate income tax was unconstitutional because other business and individuals paid no income tax, yet it might well decide that it would be an unreasonable burden if local government were to impose a heavier impost on unincorporated business than the state places on corporations. The percentage limit on mercantile license taxes, in conjunction with the prohibition against all taxes on mining and manufacturing, should prevent this problem from arising.

64. Dole v. Philadelphia, $337 \mathrm{~Pa} .375,11$ A.2d 163 (1940) held that this did not defeat the uniformity requirements of the Constitution. The tax on "coal mined" struck down as to corporations in Jamison Coal and Coke Co. v. Unity Township School Dist., 362 Pa. 387, 66 A.2d 759 (1949) was also held invalid as applied to unincorporated producers, but this was solely on the ground that the whole ordinance would not have been passed if the school district had realized that it was invalid as applied to corporations. 
unincorporated businesses, but it would seem that such a tax would be a real property tax and therefore exempt by the rental income holding of the Murray case ${ }^{65}$ from Act 481 on the ground that the legislature has provided another, more specific, means for taxing realty.

All of the taxes levied by the Philadelphia ordinance were struck down in the Murray case, not on the basis that failure of a few major taxes destroyed the system of the law, but rather on the ground that each and every one of the important taxes levied was open to some objection. ${ }^{66}$ Thus even taxes on banks, trust companies, and other corporations exempt from the general state corporation taxes were struck down, either on the ground that the special taxes they pay are equivalent to the general state taxes or through specific exemptions from local imposts granted by earlier statutes. ${ }^{67}$

While all of the above cases were decided on the basis of the act's prohibition against conflict with state taxes, taxes on rental income were struck down on entirely different grounds. It was held both that taxes on such income would violate the constitutional requirement of uniformity and also that Act 481 was not intended to allow evasion of the more detailed statutory method of taxing realty. Both of these objections are founded on the court's premise that taxation of income is taxation of the source and that thus any tax on rental income is on the realty itself. Aside from these technical grounds this decision is also obviously correct on policy grounds since the history of the Act shows that it was to be only a supplement to the real estate tax. The failure specifically to exclude realty from the list of taxables was probably inadvertent, though it must be admitted that there is no such exclusion. Yet the court has also held that the fact that the state already has a system of local taxation of personal property ${ }^{88}$ does not bar the levy of additional personal property taxes under Act $481 . .^{69}$

\section{The State License Fee Exclusion}

The exclusion of taxes on "privileges, transactions, subjects, occupations or personal property subject to any State . . . license fees" has also

65. "The legislature has provided a method (PA. STAt. ANN., tit. 53, \& 4805.1, Purdon, 1949 supp.) for taxing property in Philadelphia. . . Taxation of the income from real estate is taxation of the real estate which produces the income." Murray v. Philadelphia, $364 \mathrm{~Pa} .157,170,71$ A.2d 280 (1950).

66. The following taxes were specifically discussed and struck down: dividend income from corporations paying capital stock tax @165, dividend income from corporations paying net income tax @169, dividend income from corporations paying franchise tax @170, rental income@170, dividend income from banks@172, income of corporations paying the franchise, capital stock, or net income taxes @174, income of saving fund societies@174, income of credit unions specifically exempted @175. Then at pg. 176 the court decided that the severability provision of the ordinance would not save what was left since the main structure of the Act had fallen. Then the court went on to attack as vague anyway the remaining provisions as to capital gains and estates and trusts.

67. See note 37, supra.

68. PA. Stat. ANN., tit. 72, §4821 (Purdon 1949).

69. Though these taxes are authorized by the state they are not "state taxes" within the meaning of the prohibition against duplication of state taxes. McClelland v. Pittsburgh, $358 \mathrm{~Pa}$. 448, 57 A.2d 846 (1948). 
raised some interesting problems. The court has held in Pittsburgh Milk Co. v. City of Pittsburgh ${ }^{70}$ that these words are to be read literally and that conflict is forbidden with all license fees, not only those which are imposed for revenue purposes. ${ }^{71}$ The court feels that the plain meaning of the statute prevents it from adopting the generally accepted distinction between licenses issued for revenue and those issued as a regulatory measure. $^{72}$ This "plain meaning" is adopted even though no conceivable evil would result from subjecting those who pay only the latter type to local taxes. Thus in the Pittsburgh Milk case it was held that a $\$ 300$ annual state fee, intended to cover costs of inspection, deprived the city of taxing power. However the court has been unwilling to carry this to the ridiculous extremes which the plain meaning doctrine and the Pittsburgh Milk case suggest. Thus in the Rice Drug Co. case, ${ }^{73}$ decided the same day as Pittsburgh Milk, it was decided that a $\$ 1$ charge made by the state for a permit to sell cigarettes did not rise to the dignity of a "license fee," but was rather merely "a nominal charge to inform the Commonwealth of the identity of sellers of cigarettes."

In Armour and Co. v. Pittsburgh ${ }^{74}$ it was alleged that the payment of a $\$ 10$ annual license fee to the state should excuse the plaintiff from the payment of $\$ 30,000$ in mercantile license taxes. Here, even though the state law specifically called the fee a license, the court followed Rice Drug rather than Pittsburgh Milk. Thus while the court has refused to follow the traditional dual classification of licenses, it has seemingly set up a test of its own-if the state fee is small it will refuse to find a legislative intent to excuse from local taxation. Whether the state fee is intended to be a source of revenue or merely to cover the cost of regulation is not in itself made part of the test.

\section{The 1949 Amendments to Act 481}

The 1949 session of the General Assembly limited the tax everything philosophy of Act 481 by inserting a list of specific exceptions.

It could be said that the 1947 Act really had only one basic exception, "property subject to state tax or license fee." The other two listed exceptions were probably mere surplusage. The exception for public utilities regulated by the Public Utility Commission ${ }^{75}$ was hardly necessary since they already were taxed by the state. ${ }^{76}$ As to the prohibition against

70. 360 Pa. 360, 62 A.2d 49 (1948).

71. Ohio reached a contrary result on this question. Loan Co. v. Carrel, 106 Ohio St. 43, 138 N.E. 364 (1922).

72. 9 Dillon, Municipal Corporations $\$ 68.15$ (3d ed. 1950).

73. Rice Drug Co. v. Pittsburgh, 360 Pa. 240, 61 A. $2 d 878$ (1948).

74. 363 Pa. 109, 69 A.2d 405 (1949).

75. The 1949 Act does strengthen this exception by also excluding taxes "on any privilege or transaction involving the rendering of any such public utility service." See note 43 sispra.

76. Pa. Stat. Ann., tit. 72, §2181 (Purdon 1949). 
taxes on the privilege of employing tangible property subject to State tax, the court indicated in the Hampton case that it would probably have been willing to imply this exception anyway from the first (basic) exception.

The first new exclusion, forbidding taxes on goods manufactured in the locality, is intended to protect the state's manufacturing interests. It was felt both that such companies are already contributing an adequate share to Pennsylvania revenue, ${ }^{77}$ since they pay in much of the money flowing into Harrisburg, ${ }^{78}$ as well as local property taxes, and that it would be unwise to leave such tempting non-voting targets within the sights of vote conscious local officials..$^{79}$

The exclusion has already brought several cases into court on the question of what is manufacturing. In Rieck-McJunkin 80 the court reached the result that milk products which contain the word "milk" in their names (e.g. chocolate milk, homogenized milk, etc.) are not within the manufacturing exclusion while those which do not (cheese, butter, etc.) are "manufactured." Armour and Co. v. Pittsburgh raised similar problems as to meat products. ${ }^{81}$

Both of these cases present growing pains which could hardly have been avoided though it might have been preferable to have set up an expert commission to settle such questions rather than to expect a judicial body to juggle such metaphysical questions as whether ham and lard are manufactured products. ${ }^{82}$

Another interesting problem raised by this exception which has not yet reached the court is the question of where the manufacturing process ends, that is, whether a manufacturer who sells his own product to the public is exempt from local taxation completely, and if so, whether a retailer who sells on an agency basis can claim exemption on the ground that the supplier is the only "seller" involved and he is selling goods of his own manufacture. Such an extension of the exemption would be far broader than protection of manufacturing requires but might well be found by a strict reading of the Act.

77. Excluded are taxes "on goods and articles manufactured in such political subdivision ... or on minerals . . and farm products produced in such political subdivision ... or on any privilege, act or transaction relating to the business of manufacturing." This exemption is not limited to corporations. See note 43 supra.

78. See note 10 , supra.

79. See Rose, Pennsylvania's Experinnent in Home Rule Taxation as it Affected the Coal Industry, 11 U. of PITr. L. REv. 228 (1950).

80. Rieck-McJunkin Dairy v. Pittsburgh School District, $362 \mathrm{~Pa}$. 13, 66 A.2d 295 (1949).

81. 363 Pa. 109, 69 A.2d 405 (1949) (ham and lard held not manufactured).

82. "The process of manufacture brings about the production of some new article by the application of skill and labor to the original substance or material out of which such new product emerges. If however there is merely a superficial change in the original materials or substances and no substantial and well-signalized transformation in form, qualities and adaptability in use quite different from the original it is not manufactured." Id. at 116 . 
The second new exclusion under the 1949 Act is that school districts cannot tax the income of non-residents. Of course, every citizen lives in both a school district and a city, borough or township. The reason for thus limiting only school districts and continuing to allow other units to tax non residents is not clear, but might be justified on the basis that while the non-resident worker enjoys the benefits of streets, police protection and other municipal activities he gets no such benefit from the schools located at his place of employment. However this provision more likely represents merely a very minor victory for the forces which oppose taxation of non-residents on principle.

Of course, by the Murray case, the only income taxable by any local entity is earned income, but these so-called "wage taxes" have become a popular source of revenue. ${ }^{83}$ In fact, the pre-emption provisions of the law encourage the levy of such taxes by providing that while the town where a man is employed may tax wages of a non-resident it loses this right to the worker's place of residence if the latter levies such a tax.84 Naturally residential communities are especially anxious to reach this source of revenue when it is clear that many of their residents must pay somewhere in any event.

The third new exclusion, "personal property subject to or exempt from the County Personal Property Tax" has virtually no significance as to property exempted from the Personal Property Tax law since the chief ground of exemption is "liability to or exclusion from the capital stock or franchise tax" 85 which would serve also to exempt such property automatically from taxation under Act 481. As to taxes on personal property subject to County taxes, this provision does represent a laudable addition to the scheme of local government taxation insofar as it prevents a type of double taxation previously ignored by the Act, two or more local units taxing the same property. ${ }^{86}$ This is a problem which the new law solves generally by providing that if more than one political subdivision levies a tax on a subject to which the Act applies a maximum taxation limit, then the limits of taxation provided for in the Act shall still apply and the taxes shall be apportioned so that the total does not exceed the linit. Duplication of taxes other than those with specific limits is not provided for, but is highly unlikely to arise since limits apply to all taxes which would be likely to create the problem.

83. See note 61 , supra.

84. This is not true of Philadelphia where the wage tax is levied under the Sterling Act since Act 481 provides that any taxing resolution prior to the passage of Act 481 shall have first priority. PA. Stat. ANN., tit. 53, $\$ 2015.5$ (Purdon, Supp. 1949).

85. Pa. Stat. Ann., tit. 72, $\$ 4821$ (Purdon, 1949). See note 69, supra.

86. In Glen Alden Coal Co. v. Thomas, 165 Pa. Super. 199, 67 A.2d 754 (1949) it was held that there was nothing in the 1947 Act to prevent a co-terminus borough and school district from each levying a $1 \%$ wage tax. The earlier provision for preventing duplication of wage taxes had talked only of crediting taxes laid by place of residence against those levied by place where employed. Of course, in this situation both districts were the place of residence. 
The 1949 amendments also provide for an overall limit on the amount of money which each district is allowed to raise through the assorted taxes of Act $481,{ }^{87}$ and also limit specific types of taxes, e.g., per capita $\$ 10$, amusement $10 \%$, etc. ${ }^{88}$ While there is no quarrel with the latter provision, the overall limit does seem to be more controversial. It is obviously intended to insure that the property tax remain as the keystone of local taxation ${ }^{89}$ and to prevent small units from shoving the entire cost of local government onto one industry. Whether it was necessary to so limit all taxes, even such as the wage tax, in order to achieve this end may be questioned.

\section{ConCLUSION}

Any critique of the Pennsylvania Fome Rule Taxation Act must concern itself with two phases of investigation. The primary question is whether locally responsible taxation is the more desirable alternative to a system of state grants, and secondly is the question of whether Act 481 is the best method of raising revenue locally. The 1949 report of the Pennsylvania Tax Revision Commission ${ }^{90}$ gives a qualified answer to the first question and a negative answer to the second. It suggests that the state amend its Constitution so as to allow an effective state income tax, using a sales tax to raise revenue until this can be done, so that "Commonwealth-mandated increases in local costs be financed by means of a broad-based, Commonwealth imposed tax." It also suggests that school districts be limited to real estate and per capita taxes, and that other units be restricted under Act 481 to per capita taxes and taxes on wages and profits of unincorporated and professional activity.

The Commission report would deprive local government of its power to tax such things as amusements, deed transfers, mechanical amusement devices, and mercantile licenses. Yet with the exception of mercantile licenses, these constitute a rational and orderly supplement to the tax structure of the Commonwealth, which is otherwise based so largely on corporate taxes to finance the state government and real estate taxes to

87. The limit is 10 mills in boroughs, cities and townships and 15 mills in school districts. This does not affect the overall limit of tax revenues to which the various districts remain subject. Thus the total revenue of second class school districts remain limited to 20 mills, and of other districts to 25 mills. PA. STAt. ANN. tit. 24, §6-672 (Purdon, 1950). Third class cities are still limited to 15 mills for general revenue purposes, plus whatever is necessary for debt service. PA. STAT. ANN., tit. 53, \&12198-2551 (Purdon, Supp. 1950). Other cities, boroughs, etc. have comparable limits.

88. Per capita, poll and head taxes-\$10; varying rates of 1 to 2 mills on taxes on volume of business transacted; earned income taxes, $1 \%$; retail sales taxes, $2 \%$; real property transfer taxes, $1 \%$ admissions, $10 \%$.

89. The real estate tax supplied $75.8 \%$ of local revenues before Act 481 . Report \#11 of the Tax Advisory Committee, Proposals for Revision of the Tax Structure of the Commonwealth of Pennsylvania, 212. Act 481 guarantees that a minimum of $25 \%$ to $40 \%$ of local revenue will continue to come from this source. See note 87, supra.

90. $3 \mathrm{CCH}$ Pa. State TAx Rep. 10,442. Since this report was made available to the legislature before the 1949 amendments were passed it evidently does not reflect the opinion of that body. 
finance local government.91 Insofar as these taxes levied under Act 481 strike at luxuries or business transactions not otherwise taxed they seem wise.

The idea of having the State list affirmatively what taxes are permissible is a most obvious change which could be made in Act 481 . The only objection to it is that experimentation would thereby be cut off. However the value of such experimentation is questionable since it is difficult to conceive that any local unit will discover a new tax which has not yet been tried somewhere before. On the other hand, if the list were made long enough the advantage of allowing communities to levy only such taxes as their special needs warrant could be maintained. While this course would have avoided much litigation in the past three years if it had been adopted originally it is now probably unnecessary since Act 481 has been so thoroughly interpreted by the Court that most potential taxes have already had their validity passed upon or are not open to serious doubt. However, since the vast majority of the court's decisions are not on constitutional grounds, the legislature has full power to overrule the court and decide that it would be advisable to grant certain power to the localities. ${ }^{92}$ Thus the legislature might well scrutinize the decisions in order to see whether it is in agreement with the results. The most controversial decisions are certainly those legalizing the mercantile license $\operatorname{tax}^{93}$ and forbidding local taxes on income from tangible property. ${ }^{94}$ The former represents the only deviation from the economic burden theory. Its existence casts doubts on the economic validity of the entire scheme of exempting those already burdened with state taxes. The latter exempts from local taxation a class which derives income locally which cannot be reached in an effective manner by means of property assessments alone.

The double tax prohibition as interpreted by the court has prevented the existence side by side of taxes which traditionally have not been believed to be in disharmony. Insofar as Act 481 was intended primarily to reach a new class of taxpayers rather than to impose new taxes on the old taxpayers the result is justified. As the taxation of this new class develops however some attention will have to be paid to the problem of securing the fullest utilization of the tax potential. The state taxes on corporations have achieved this by using both an asset value and an income measure. 95 Taxes on earned income of individuals by their very nature can have but one measure. However, as to taxes on the tangible assets of individuals the Murray case forestalled the levy of any tax based on income. Thus on such property profitable investments yield no greater tax

91. See notes 10 and 89 , supra.

92. The important decisions limiting local taxation of corporations have all come since the last session of the legislature so that it is not yet possible to tell whether they will evoke any legislative reaction.

93. Federal Drug Co. v. Pittsburgh, 358 Pa. 454, 57 A.2d 849 (1948).

94. Murray v. Philadelphia, $364 \mathrm{~Pa} .157,71$ A.2d 280 (1950).

95. See text at note 38 , supra. 
return to the commonwealth than unprofitable ones except insofar as earning capacity is reflected in value. There would seem to be no real economic reason for forbidding the taxation of income from individually owned realty, while so long as such taxes are forbidden the real estate tax will remain essentially inequitable in many situations.

An accusation that has often been hurled against Act 481 is that it thwarts the finding of new sources of income by the Commonwealth which hesitates to impose any new taxes for fear of wrecking the tax structures of communities which are already using these sources and would have to give up whichever ones were pre-empted by the state. ${ }^{96}$ It is questionable whether this is really a vital objection since even if a community is forced to give up a tax which it has levied under Act 481 it has greater freedom to shift to other sources than it would have had in the absence of the law. If a tax such as the Philadelphia Wage Tax does become so essential locally that there would be a great hardship in wiping it out ${ }^{97}$ then there would be nothing to prevent the state from amending Act 481 so as to allow such a tax to exist side by side with a duplicate state tax. In addition, by increasing the revenues of local government Act 481 was intended to forestall the need for any additional statewide sources of revenue.

One basic weakness of Act 481 is that no attempt can be made to equalize tax burdens between those paying the state and those paying local government. Thus in the Armour case ${ }^{88}$ the defendant had a very strong argument that $\$ 10$ in state license fees exempted him from the grasp of local taxing authorities (who had imposed $\$ 30,000$ a year in taxes on the company). This is an example of the kind of situation which can exist in the absence of over-all tax planning. There are two aspects of such planning. First must be considered the equities as between groups subject to state taxation and those taxed locally. Second is the problem of competitors (corporations v. unincorporated business) who may derive a substantial advantage from being subject to one governmental body rather than the other. The first problem involves essentially little more than the question of apportionment of expenses as between the two levels of government. The second problem involves administrative difficulties which are part of the price of the system. Little more can be done than to keep the tax limits low enough to maintain local business taxes at or below the general level of state taxation.

A second weakness of Act 481 is that it is clearly a breeder of litigation. If a hundred different towns levy mercantile license taxes or wage taxes with different provisions and exceptions each must be tested separately, whereas in the old system only one law had to be tested in order finally to settle an issue. However this objection can be overstated since

96. Phila. Evening Bulletin, Editorial, Feb. 27, 1951.

97. Total tax revenue from all taxes levied under Act 481 is 25 million dollars per year. The Philadelphia Wage Tax, levied under the Sterling Act, amounts to 40 million dollars per year. Phila. Evening Bulletin, Editorial, Feb. 27, 1951.

98. Armour and Co. v. Pittsburgh, 363 Pa. 109, 69 A.2d 878 (1948). See text at note 74 , supra. 
most units will no doubt copy an ordinance which has stood the test of judicial scrutiny. Still, as local special interests get themselves exempted or favored, the prior court test will be no guarantee as to whether the new ordinance's classifications remain reasonable.

As to the question of whether local government should be trusted with the responsibilities of levying its own taxes or whether such functions should be in the state, the desirable solution is obvious from traditional American concepts of democracy. Pennsylvania has made a sincere attempt to turn the tide of centralization and prevent boroughs and townships from becoming mere administrative districts. The small town is nowhere in America as prevalent as it is in Pennsylvania.99 Here, if anywhere, local government should be able to rule itself by paying for its own functions. ${ }^{100}$ It is not suggested that local units be expected to pay for services which are primarily for the benefit of the state as a whole, such as main highways. However if local government is not able to take the responsibility of paying for its own hospitals, schools, and roads then local self-government is no more than a pious fiction.

However, as undesirable features of local autonomy appear, especially evidence of local irresponsibility, to that extent taxing powers should be taken away from the local unit. It is not only the extreme cases of deprivation of due process and equal protection which must be considered, but also the practical danger of driving business from the state. It is this danger, more than any question of "double taxation" which justifies the result of the decisions which have had the effect of taking away the power to tax corporations. The court has implemented this policy through the use of its doctrine that since the value of property is in its use, a tax on the use or the privilege of using is a property tax. The court's one deviation from this concept, the upholding of the mercantile license tax, is seemingly indefensible either on doctrinal or policy grounds.

This doctrine has generally had the salutary effect of reconciling local discretion with protection of corporate enterprise, even though it has resulted in a broader exception than necessary to the earned income of individuals. It would have been too naive to expect local officials to be temperate when the issue is whether new taxes should be raised from the voters or from the one or two corporations in town. Thus this major potential deficiency in the system has been remedied by the courts without destroying the democratic basis in which the law remains rooted.*

99. Pennsylvania has 892 communities with populations of over $1000,60 \%$ more than any other state. Its total of 4563 communities is also higher than that of any other state. Information Please Almanac 226 (1949). Act 481 covers 3588 governmental units. Burkhead, Permissive Local Taxation in Pensylvania, 1948 Proc. Nat. Tax Assoc. 12, 19. (1950).

100. Fordham and Mallison, Local Income Taxation, 11 OHIo ST. L. J. 221, 269

* To offset the veterans' bonus a state income tax has been proposed, with an amendment to Act 481 expressly allowing local wage taxes. This will raise problems of double taxation; but it appears that local officials will adjust their taxes in light of the state levy. 


\section{"Wilful Misconduct" and the Pennsylvania Unemployment Compensation Act}

Unemployment compensation is designed to cushion the shock of a sudden loss of the wage-earner's chief source of income. The state laws broadly limit eligibility for payments to those whose condition of unemployment is not due to circumstances within the worker's own control. Thus, compensation is everywhere denied or temporarily suspended where the claimant has quit his job without cause, or where, once out of work, he has refused suitable reemployment. ${ }^{1}$ Another common statutory ground for benefit disqualification exists where the claimant's unemployment has resulted from certain kinds of misbehavior on his part. The vast majority of state compensation statutes provide for ineligibility where the worker was discharged for "misconduct;" 2 Pennsylvania disqualifies those claimants whose employment was terminated for "wilful misconduct." 3 A recent Superior Court decision, the Sabatelli Unemployment Compensation case, ${ }^{4}$ raises the issue whether the Pennsylvania statutory formulation calls for the application of a stricter test than is employed in the majority of jurisdictions.

The administrative and judicial decisions to date disclose no significant difference between Pennsylvania's standard of eligibility and other state tests. It is fundamental that misconduct, for the purposes of unemployment compensation, does not embrace all moral transgressions or even all acts of a criminal nature. ${ }^{5}$ The standard against which the conduct is measured is fixed by the duties arising, either directly or by implication, out of the employment relationship. ${ }^{6}$ Disqualification will result where the claimant's discharge was caused by excessive absenteeism from the job, ${ }^{7}$ drinking, ${ }^{8}$ sleeping, ${ }^{9}$ or gambling ${ }^{10}$ on company time, brawling in the plant, ${ }^{11}$ and insubordination to the employer's authority. ${ }^{12}$

1. Soctal Security Board, Unemployment Compensation Laws as of Oct. 1 , 1940, 94-96, 99-101 (Employment Security Memo. No. 8, Revised Oct., 1940).

2. Id. at $96-99$.

3. Act of May 29, 1945, Pa. Stat. Ans., tit. 43, \$802(e) (Purdon Supp. 1950) provides: "An employee shall be ineligible for any week ... (e) In which his unemployment is due to his discharge . . . for wilful misconduct connected with his work."

4. $168 \mathrm{~Pa}$. Super. 85, 76 A.2d 654 (1950).

5. See Kempfer, Disqualification for Voluntary Leaving and Misconduct, 55 YALE L.J. 147, 162 (1945).

6. Pennsylvania's requirement that the misconduct be "connected with" the discharged employee's work is typical. See note 3 supra.

7. E.g., 1A CCH Unempl. Ins. Serv. Ala. I 1970.028 (Ala. 1943); 6 id. Pa.

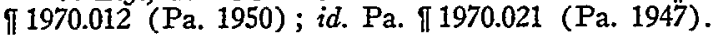
(1948).

8. Guede v. Unempl. Comp. Bd. of Rev., $162 \mathrm{~Pa}$. Super. 479, 58 A.2d 197

9. Laney v. Unempl. Comp. Bd. of Rev., $167 \mathrm{~Pa}$. Super. 551, 76 A.2d 487 (1950).

10. $6 \mathrm{CCH}$ UNempl. Ins. Serv. Pa. đI 1970.37 (Pa. 1949).

11. 2 CCH Unempl. INs. Serv. Cal. $\Uparrow 1970.515$ (Cal. 1945) ; 6 id. Pa. $\llbracket 1970.075$ (Pa. 1948).

12. E.g., 6 CCH UNeMpl. Ins. Serv. Pa. $\| 1970.078$ (Pa. 1948). 
It might be supposed that any act or omission which is specifically prohibited by the employer's rules would constitute misconduct, since, by definition, such behavior violates the duties imposed by the employment relationship. This is not true, however, where the rule infraction is due simply to inadvertence or inability to remember an established routine. Thus, it is generally held that neither ordinary negligence ${ }^{13}$ nor a mere failure to meet required standards of efficiency ${ }^{14}$ will render the discharged claimant ineligible for benefits.

Where the rule violation is deliberate, the test is refined still further. If the infraction can be explained by circumstances which led the employee to believe that his deviation from the commanded course was justified, that is, where the "misbehavior" amounted to nothing more than an error in judgment, compensation will not be withheld. ${ }^{15}$ Even in the absence of justifying circumstances, the compensation authority, while not questioning the prerogative of the employer to discharge a worker for the most venial infraction, may inquire into the seriousness of the transgression. Although the state law speaks only of ordinary misconduct, it is not unusual to find an administrative limitation in the form of a rule of decision that, in order to bar compensation, the violation must have a substantial effect on the employer's interest. Compensation has been allowed, for instance, where the discharge was caused by violation of a command against speaking to female employees on the job. ${ }^{16}$ Similarly, single ${ }^{17}$ or infrequently repeated ${ }^{18}$ violations will not disqualify the claimant unless the prohibition relates to a matter which is regarded as grievous. ${ }^{10}$ Where the discharge has resulted from continued rule infractions, compensation is invariably withheld. ${ }^{20}$ The Sabatelli case seeks to establish still another limitation where the employment was terminated because of admittedly deliberate rule infractions of a substantial nature.

Claimant was discharged from his employment as a bus driver for improper registration of fares over a two-month period, in violation of a company rule. Conceding that he was guilty of misconduct, claimant contended that the element of wilfulness required by the Pennsylvania statute was lacking inasmuch as there was no showing of an intent on his part to

13. 6 CCH UNeMrL. Ins. Serv. Pa. $\llbracket 1970.73$ (Pa. 1950); id. Pa. \1970.571 (Pa. 1949); id. Pa. fl 1970.572 ( $\mathrm{Pa}$. 1949). Discharge for gross negligence is ground for disqualification. 6 UNEMPL. INS. SERV. Pa. II 1970.13 (Pa. 1950).

14. The Pennsylvania rule is illustrated in $6 \mathrm{CCH}$ Unempl. INs. SERv. Pa. II 1970.42 ( $\mathrm{Pa} .1950)$, and in id. $\mathrm{Pa}$. $\mathbb{1} 1970.44$ ( $\mathrm{Pa}$. 1947).

15. $6 \mathrm{CCH}$ UNEMPL. INS. SERV. Pa. $\pi 1970.958$ (Pa. 1947). (Pa. 1949).

17. CCH Unempl. Ins. Serv. New York $\llbracket 1970.67$ (Ref. Dec. 516-123-38R); $6 \mathrm{CCH}$ Unempl. Ins. Serv. Pa. $\int 1970.941$ (Pa. 1950).

18. $4 \mathrm{CCH}$ Unempl. Ins. Serv. Mich. đI 1970.03 (Mich. 1948); 6 id. Pa. If 1970.944 ( $\mathrm{Pa} .1947)$.

19. E.g., 2 CCH UNEMPL. INS. SERv. Conn. II 1970.051 (Conn. 1947) (violation of rule against discussing war, where purpose was to prevent production-disrupting altercations); $5 i d$. N.C. $\llbracket 1970.411$ (N.C. 1940) (violation of strictly enforced nosmoking rule).

20. E.g.j $6 \mathrm{CCH}$ Unempl. INs. Serv. Pa. \1970.948 (Pa. 1948); id. Ohio II 1970.33 (Öhio 1940); id. Tenn. โI 1970.03 (Tenn. 1938). 
defraud the company but simply a careless disregard of the company's rules. The court rejected this contention and sustained the administrative finding of wilful misconduct on the ground that claimant's behavior evinced a conscious indifference to his employer's welfare.

The term "wilful" literally imports an element of volition or deliberateness. Strictly conceived, only intentional misbehavior seems to be contemplated by the statute. However, granting that the element of intent is essential, a further question arises, and one which is crucial to the present decision. To come within the defined area, must the actor have intended the harmful consequences of his wrongful act, or is it enough that he intended the mere doing of the act itself? The present claimant pressed the argument that, although his failure to register fares constituted misconduct, the statutory definition was not satisfied in the absence of proof that he intended thereby to injure the company.21

There is authority for claimant's position that one is not guilty of wilful misconduct where he does not actually intend the injury which follows his wrongful behavior. In contrasting recklessness with intentional misconduct, the Restatement of Torts makes the point that essential to the latter is an intent to cause the harm which results from the act, as distinguished from the intent simply to do the act itself. ${ }^{22}$ In an earlier comment, however, the drafters of the Restatement call attention to the practice among courts and legislatures in the Torts field of describing as "wilful or wanton," conduct which contains no element of actual intent, but which is merely an aggravated form of negligence. ${ }^{23}$ An example of this practice is found in Pennsylvania in that body of case-law which holds that conduct in reckless disregard of the safety of another is sufficient to establish tort liability where the actor is under a duty merely to refrain from wilful or wanton misconduct toward the suing party. ${ }^{24}$

Illustrative of such cases is Kasanovich $v$. George, ${ }^{25}$ which construed the duty of a street car operator toward a pedestrian whose perilous position was known to the former. It was there stated that "wantonness exists where the danger to the plaintiff, though realized, is so recklessly disregarded that, even though there be no actual intent, there is at least a willingness to inflict injury, a conscious indifference to the perpetration of the wrong." 26 The present court uses language virtually identical with that in the Kasanovich passage, but simply substitutes "wilfulness" where that opinion uses the term "wantonness." 27 The result is an introduction into the law of Unemployment Compensation of an erroneously labelled

21. It appears that the Board found affirmatively that claimant was not trying to defraud the company. $168 \mathrm{~Pa}$. Super. at 88, $76 \mathrm{~A} .2 \mathrm{~d}$ at 656.

22. RESTATENENT, TORTS $\$ 500$, comment f. (1934).

23. See Special note, id. at p. 1293.

24. See the cases collected in Note, Those Weasel Words- "Wilful and Wanton," 92 U. OF PA. L. REv. 431 (1944), where the writer discusses the duty of a land owner toward trespassers, and the liability of a master for the conduct of his agent toward truck passengers riding in violation of the master's order.

25. 348 Pa. 199, 34 A.2d 523 (1943).

26. $I d$. at 203,523 .

27. 168 Pa. Super. 85, 88-89, 76 A.2d 656 (1950). 
notion of misbehavior, whose confusing effects had been heretofore limited principally to the field of Torts. In fact, by equating "wilful misconduct" with "wilful or wanton misconduct," the instant case proceeds one step further in the direction of obscuring the distinction between intentional misconduct and that degree of negligence which is best described as "reckless."

The Pennsylvania statute's use of the modifying adjective, "wilful," is not readily explainable. ${ }^{28}$ Conceivably the legislature did intend the standard to be that expressed by the phrase, "wilful and wanton." If so, the present court was correct in ignoring an unhappy choice of words; still, one hesitates to commend such juristic "clarification." On the other hand, it must be said to the court's credit that the result reached in this case is in accord with the unopposed weight of authority, and within the spirit of unemployment compensation legislation. The construction sought by claimant, though defensible as a matter of sheer verbalism, would prove unjust and unworkable as a matter of practice. It is difficult to conceive of a less manageable test of eligibility for benefits than that which would require the local administrative agency to inquire into the existence, at some time in the remote past, of an actual state of the applicant's mind. Moreover, to allow compensation in every case where the misconduct falls short of being quasi-criminal in character would be to give indirect sanction to myriad forms of serious employee malfeasance. The unfortunate consequence would be a practical dissipation of whatever force as a deterrent is contained in the provision for disqualification for conduct which is harmful both socially and economically. ${ }^{29}$

Perhaps the ultimate justification for the present decision lies in the fact that, in Pennsylvania, the burden of benefit payments is borne directly by the employer. In this state the rate of an employer's contribution to the unemployment compensation fund is based upon experience tables which record all benefits paid out of the fund to his former employees. ${ }^{30}$ While it is true that a denial of compensation may in some cases result in the unemployed's becoming a community charge, nevertheless, where his condition of unemployment is attributable to a severely reprehensible disregard of the employer's welfare, considerations of justice demand that the onus of supporting him be shifted from the employer to the public at large. ${ }^{31}$

28. The provision appears to have come in without debate or clarification by either branch of the state legislature. 3 PA. LEGrs. Jour. 2899 (1945); 4 id. 3785 (1945).

29. At least one state has taken a position similar to the Pennsylvania Court's where the same question arose in connection with eligibility for payments under the local Workmen's Compensation Statute. Stockdale v. Industrial Comm'n, 76 Colo. 494, 232 Pac. 669 (1925). See 6 Schneider, Workmen's Compensation Text, 339 (1948).

30. Act of Dec. 5, 1936, P.L. (1937) 2897, art. III, $\$ 301$, as amended, Act of May 26, 1943, P.L. 639, No. 283, § 1, PA. Stat. ANn., tit. 43, §781 (Purdon Supp. 1950).

31. The Pennsylvania Board had previously adhered to the rule adopted in the present case. See 6 CCH UNEMPL. INS. SERv. Pa. II 1970.80 (Pa. 1947). For similar New York administrative rulings, where benefit rights are suspended for "misconduct" merely, see CCH (UNEMPL. INS. SERV. NEw YORK 1970.67 (Ref. Dec. 535-10-39R); id. T1970.67 (App. Bd. Dec. 223-38, Sept. 7, 1938). 


\section{The Pennsylvania Court and Retroactive Effect of Recent Legislative Provisions}

In recent years the Pennsylvania Supreme Court has several times been asked to strike down important legislation so far as it affected existing property rights. In each instance the court has done so. This article is concerned with the approach of the present court to such retroactive legislation.

Conceding that it is the duty of a legislature to enact prospective law, the issue becomes, to what extent can a legislature alter the status quo as well. There is substantial unanimity upon the verbal formulation of a doctrine. A legislature may not declare that property now vested in A shall henceforth belong to $B .^{1}$ But property not vested in $A$, in which A has only a mere expectancy, is subject to retroactive laws. ${ }^{2}$ Legislation which is curative may reach into the past; for example a marriage defective for non-compliance with some technicality may be validated. ${ }^{3}$ A new remedy may replace an old, provided that no vested right is impaired. ${ }^{4}$

Originally the Pennsylvania courts exhibited little or no opposition to retroactive laws. The court in 1849 explained Pennsylvania's position to be a result of its inability to interfere with the demands of the legislature and the bar. ${ }^{5}$ In cases involving curative legislation it was confidently maintained that no rule forbade retroactive laws even where they impaired vested rights. ${ }^{6}$ Rather than distinguish between vested and nonvested rights inquiry was to be made as to whether or not the legislature had assumed to exercise the judicial function of taking property from one to satisfy the private right of another. If so, the legislation was "prohibited" because a legislature may not alter rights except for public purposes. ${ }^{7}$ Curative legislation was, of course, of the "authorized variety." 8 On the other hand, where legislation was not of the curative variety, the courts early spoke of vested rights and held such retroactive laws to be violative of the law of the land, Pennsylvania's due process. ${ }^{9}$ The present

1. See, e.g. Wilkinson v. Leland, 2 Pet. 527, 657 (U.S. 1892) ; Palairet's Appeal, $67 \mathrm{~Pa}$. 479, 486 (1871); II Cooley's Const. Limitations 745 (8th Ed. 1927); White, Const. of PA. 130 (1907) ; cf. Danforth v. Groton Water Co., 178 Mass. 472, 476, 59 N.E. 1033,1034 (1901).

2. See Crawford Estate, 362 Pa. 458, 464, 67 A.2d 124, 127-8 (1949); II Cooley's Const. Linmitations 750 (8th Ed. 1927).

3. Inhabitants of Goshen v. Inhabitants of Stonington, 4 Conn. 209 (1822); cf. Underwood v. Lilly, 10 S. \& R. 97 (Pa. 1823).

4. Commonwealth v. Commissioners, 23 Mass. 501, 508 (1828); Willard v. Harvey, 24 N.H. 344, 352 (1852).

5. See Greenough v. Greenough, $11 \mathrm{~Pa} .489,495$ (1849).

6. Grim v. Weissenberg Sch. Dist. $57 \mathrm{~Pa} .433$ (1868); see Palairet's Appeal, $67 \mathrm{~Pa} .479,485$ (1871).

7. See Grim v. Weissenberg Sch. District, supra at 437. (1939).

8. Lane v. Nelson, 79 Pa. 407 (1875) ; Wait's Estate, 336 Pa. 151, 7 A.2d 329

9. Brown v. Hummel, $6 \mathrm{~Pa} .86$ (1847). Under the doctrine that vested rights may not be impaired, but non-vested rights may be, the following results have been obtained: estates tail may be retroactively abolished. See Crawford Estate, $362 \mathrm{~Pa}$. $458,465,67$ A.2d 124, 128 (1949). The legislature can provide that joint tenancies 
court follows the doctrine that vested rights may not be impaired, but reinforces that doctrine with extraordinary emphasis upon stare decisis. As will be seen, the approach of the court since 1947 has been to strike down retroactive laws for the reason that they conflict with property interests as previously defined by the court.

The Willcox ${ }^{10}$ case in 1947 is the first of the important recent decisions. This widely known case struck down a community property law which the Legislature had enacted for the purpose of giving to Pennsylvanians the income tax advantage enjoyed by the citizens of community property states. One among many reasons for the invalidity of this law was the fact that it would take the income from property previously belonging to the husband and give it to the wife. ${ }^{11}$ For present purposes it is significant that Justice Horace Stern's opinion does not contain the formulation the court has used since 1949. He did not state that since a right to income had been previously defined to be vested, Q.E.D. it could not be impaired. Rather, Justice Stern's analysis concerns itself with the extent to which regulation of spouses' rights is permissible.

In 1949 the Craveford ${ }^{12}$ case was decided. The provision of the legislature here assailed was the Pennsylvania version of the section of the Uniform Principal and Income Act allocating stock dividends to re maindermen.13 This statute accomplished a significant change in Pennsylvania law, for by the "Pennsylvania rule" only such part of a stock dividend as is necessary to support the intact value of corpus goes to remaindermen. ${ }^{14}$ The balance is the property of life tenants. The argument before the court in Crazeford's Estate was between life tenant and remaindermen as to the right to stock dividends arising from a trust created prior to enactment of the new law. The court decided that since the life tenant had a vested right to income as apportioned by the Pennsylvania rule, the statute could not operate retroactively. The opinion by Justice Allen Stearne rests upon stare decisis. It reviews decisions wherein property rights have been held to be vested, and concludes: "Where a decision of the Supreme Court of Pennsylvania declares an interest to be vested, no retroactive statutory enactment may modify or extinguish it." 15

be construed as tenancies in common. Bambaugh v. Bambaugh, 11 S. \& R. 190 (Pa. 1824). But perpetual ground rents may not be retroactively disturbed. Palairet's Appeal, $67 \mathrm{~Pa}$. 479 (1871). A deficiency judgment act was sustained after the Supreme Court approved a similar New York law. Pennsylvania Co. v. Scott, 346 Pa. 13, 29 A.2d 328 (1942). Compare Beaver County Bldg. \& Loan Ass'n. v. Winowich, 323 Pa. 483, 187 Atl. 921 (1936) with Klinke v. Samuels, 264 N.Y. 144, 190 N.E. 324 (1934). The retroactive effect of statutes attempting to validate women's deeds and to allow inheritance by illegitimates has been struck down. Elder v. Elder, 256 Pa. 139, 100 Atl. 581 (1917). Appeal of Edwards, $108 \mathrm{~Pa} .283$ (1885).

10. Willcox v. Penn Mutual Life Ins. Co., $357 \mathrm{~Pa}$. 581, 55 A.2d 521 (1947).

11. See Willcox, supra at 590-593, 55 A.2d at 525-527.

12. 362 Pa. 458, 67 A.2d 124 (1949).

13. Compare PA. Star. ANn., tit. 20, $\$ 3470.5$ (Purdon Supp. 1949) with Uniform Principal and Income Act, $\$ 5(1)$.

14. Waterhouse's Estate, $308 \mathrm{~Pa}$. 422, 162 At1. 295 (1932) ; Nirdlinger's Estate, 290 Pa. 457, 139 At1. 200 (1927).

15. Crawford Estate, 362 Pa. 458, 467, 67 A.2d 124, 129 (1949). 
The Borsch ${ }^{16}$ decision in 1949 , opinion again by Justice Stearne, carries the approach of the court in the Crawerford case one step further. The Borsch case involved a provision by the legislature that the beneficiary of a spendthrift trust could release his interest in favor of remaindermen in order to secure the tax advantage of lower rates upon lower income..$^{17}$ When the beneficiary of the spendthrift trust in Borsch Estate executed her release, she had been receiving income from the trust for over twentyfive years; the trust had been created long prior to enactment of the Estates Act provision permitting release. The Pennsylvania Court approved the refusal of the lower court to honor her release, and held that the deceased settlor had a property interest in the operation of the trust on spendthrift terms which could not be disturbed retroactively. Although the question in the Borsch case is now practically moot in view of the legislature's failure to reenact the release provision in 1947,18 the approach of the Pennsylvania court is remarkable in that it is not concerned with impairment of a vested interest. Rather, the Court takes the view that its previous delineation of a settlor's interest in spendthrift trusts as constituting property is sufficient to negative the retroactive effect of the law. ${ }^{19}$

The McKean ${ }^{20}$ case decided in 1951, opinion once more by Justice Stearne, involved the retroactive effect of the Estates Act provision which allows a widow in taking against a will to claim an interest in revocable trusts set up by her husband. ${ }^{21}$ The widow in McKean was opposed by the remainderman of such a revocable trust. The latter contended he had a vested interest in remainder even though a power of revocation had existed in the husband. The opinion of the court cited several cases, arising in a wholly different context, ${ }^{22}$ to the effect that the remainderman had a present vested interest, and concluded that this defined vested interest could not be impaired retroactively. ${ }^{23}$ Once more the court employed the Crawford formulation: if an interest has been held to be vested for any purpose no retroactive law can impair it.

The retroactivity problem is one of achieving essential fairness. ${ }^{24}$ In essence it is a balancing of the advantages of a new law against the harm to rights as they stand. This weighing of scales cannot be done without also considering the value of certainty in the law. If, for example, a rule

16. 362 Pa. 581, 67 A.2d 119 (1949).

17. Act of 1943, P.L. 797, as amended by the Act of 1945, P.L. 1337.

18. Pa. Stat. AnN., tit. 20, $\$ 301.3$ (Purdon, 1949).

19. See Borsch Estate, 362 Pa. 581, 588-589, 67 A.2d 119, 122-123 (1949).

20. $366 \mathrm{~Pa} .192,77$ A.2d 447 (1951).

21. Pa. Stat. Ann., tit. 20, $\$ 301.11$ (Purdon 1950).

22. The cases cited were: Dickerson Appeal, 115 Pa. 198, 8 Atl. 64 (1887); Lines v. Lines, 142 Pa. 149, 21 Atl. 809 (1891) ; In re Dolan's Estate, 279 Pa. 582, 124 Atl. 176 (1924); In re Shapley Trust, 353 Pa. 449, 46 A.2d 227 (1946). None concern retroactivity.

23. McKean Estate, 366 Pa. 192, 195, 77 A.2d 447, 448 (1951).

24. For full discussions see Smith, Retroactive Laws and Vested Rights, 5 Tex. L. Rev. 231 (1927), 6 TEx. L. Rev. 409 (1928) ; Smead, The Rule Against Retroactive Legislation: A Basic Principle of Jurisprudence, 20 MinN. L. Rev. 775 (1936). 
of apportioning stock dividends is to turn upon its effect upon two parties, estates administration would become hazardous business. On the other hand the present view of the Pennsylvania Court may overemphasize this consideration. Whereas predictability is now easy, even this may be a delusion. For instance, in an earlier case the court had to qualify statements of previous decisions that lay members of a church have a vested property interest in the management of church property. It was necessary to explain that these previous statements did not mean that the legislature could not transfer church property to church officers with retroactive effect. $^{25}$ At the moment, however, it is clear that the court will follow prior delineations of property. Such an approach is consistent with a theory that retroactive laws are bad per se, a theory that no analysis is needed. Several jurisdictions by constitutional mandate share such a view, ${ }^{28}$ but in Pennsylvania the court does not express any reason for its present tenet of adhering to previously defined property interests in retroactivity cases. One wishes the Pennsylvania court would set forth its analysis and reveal its method of balancing interests.

\section{Judicial Assent to Sale of Public Lands in Pennsylvania Where a Higher Bid Is Received Prior to Confirmation}

The principal object in sales conducted by public officers, whether the subject of the sale be personal or public property, is to obtain the highest price available for the property. Though techniques of sale, whether private negotiations, public auction or sealed bids will vary both with the nature of the subject matter and with statutory directions, a court generally has the power to confirm or disapprove it. Where a sale by public auction or sealed bids is utilized, if a higher bid is entered after the close of the regular bidding but prior to confirmation, the problem has often been presented to the courts whether sellers in the long run will get a better price by adopting a policy of protecting the highest regular bidder, or by a policy of reopening the sale on the receipt of an advanced bid.

A divergence of opinion on this question resulted in the prevalence of three views on the effect of the receipt of a bid higher than the highest regular bid prior to confirmation of a judicial sale. ${ }^{1}$ In some states the receipt of a higher bid is grounds for denying confirmation of a judicial sale. $^{2}$ This view, rapidly becoming an anachronism, represents the rem-

25. Canovaro v. Order of St. Augustine, $326 \mathrm{~Pa} .76,191$ At1. 140 (1937).

26. Colorado, Georgia, Idaho, Missouri, Montana, New Hampshire, Ohio, Texas, and Tennessee.

1. A judicial sale is defined as a sale under a judgment, order or decree of the court. See State College Borough v. Leathers, 19 D. \& C. 405 (Pa. 1933).

2. Even in these states, however, considerable discretion is vested in the judge. See Barnes Co. v. Davy Pocahontas Coal Co., 89 W. Va. 504, 109 S.E. 616 (1921). 
nants of the old English chancery rule which opened the bidding on an offer to advance the price $10 \%$ prior to confirmation. ${ }^{3}$ This rule was abandoned by statute in England, ${ }^{4}$ but its spirit at times seems to have influenced Pennsylvania Orphans' Court practice. ${ }^{5}$ In other states the highest regular bid must be confirmed despite a greater subsequent bid in the absence of fraud, mistake or gross inadequacy of price. ${ }^{6}$ Still other states, including Pennsylvania, hold that confirmation is within the court's discretion, i.e., the receipt of the higher bid may of itself be sufficient to prevent confirmation, but whether or not it will rests entirely with the court. ${ }^{7}$ Previously in the exercise of this discretion Pennsylvania courts have registered no displeasure over the belated receipt of increased offers for the property, ${ }^{8}$ but there are now some indications of a growing concern for the interests of the successful regular bidder. ${ }^{9}$

As distinguished from judicial sales, there are certain sales of public or private property that require judicial assent. ${ }^{10}$ The effect of the receipt of a higher bid after a sale by sealed bids where the sale required judicial assent was questioned in the recent case of In re Sale of Certain Unmined Coal. ${ }^{11}$ There, pursuant to statutory authorization, ${ }^{12}$ the County Commissioners of Fayette County offered for sale by sealed bids certain coal lands belonging to the County Institution District. A high bid of $\$ 177,500$ made by Baton Coal Company was accepted by the Commissioners, who, believing the bid to be reasonable, petitioned the Court of Quarter Sessions for approval of the sale. At the confirmation hearing a bid of $\$ 196,000$ was entered by another company. The court en banc refused to approve the sale to Baton, and ordered the Commissioners to re-offer the land for sale at a price of not less than $\$ 196,000$, finding ${ }^{13}$ that the $\$ 177,500$ bid

3. See Ballentyne v. Smith, 205 U.S. 285 (1907). 77.

4. 30 and 31 Victoria c. 48 . See Delves v. Delves, (1875) L.R. Equity (Eng.)

5. Estate of Catherine E. Murphy, 15 Phila. 530 (1882) ; 2 Hunter, PenNsxlvania OrPhans' Court, 1201 (1939); but cf. Sprankles Estate, 59 Mont. Co. L.R. 171, 175 (Pa. 1943).

6. In re Stanley Engineering Co., 164 F.2d 316 (3d Cir. 1947) ; Prentice v. Boteler, 141 F.2d 175, 177 (9th Cir. 1944) ; Prettyman v. Chandler, 174 Va. 99, 5 S.E.2d 521 (1939).

7. Clark's Estate, 38 Pa. Co. Ct. 302 (1910); Bower's Appeal, 84 Pa. 311 (1887).

8. See Fourth Avenue Regular Baptist Church v. Baille, 29 Pitts. L.J. 20 (Pa. 1881); Lapetina's Estate, 57 Mont. Co. L.R. 31 (Pa. 1940); cf. Marine National Bank v. Johnson Lumber Co., 112 Pa. Super. 139, 170 Atl. 349 (1934); Wilson v. McHale, 44 D. \& C. 93 (Pa. 1942).

9. See Pennsylvania Co. v. Broad Street Hospital, 354 Pa. 123, 47 A.2d 281 (1946); Note also PA. Stat. ANN. tit. 20, \$818 (Purdon Supp. 1949) eliminating the necessity of court assent to sale by fiduciaries under certain circumstances. See also Herbert's Estate, 366 Pa. 107, 51 A.2d 753 (1942).

10. The distinction between judicial sales and sales requiring judicial assent is discussed in 31 AM. Jur. 398 and 21 AM. JUR 92.

11. 76 A.2d 194 (Pa. 1950).

12. Pa. Stat. Ann., tit. 62, $\$ 2255$ (Purdon 1950).

13. The original order denying confirmation was based solely on the receipt of the $\$ 196,000$ bid. The record was remanded to the court for a determination of the reasonableness of the $\$ 177,500$ bid, the Supreme Court directing the lower court to dis- 
when made did not constitute a fair and adequate price, even disregarding the bid subsequent to Baton's. In affirming this order, the Pennsylvania Supreme Court held that the giving or withholding of assent to the sale was a matter which lay in the discretion of the court, and that the lower court did not abuse its discretion. Thus the rule is established in Pennsylvania, that in both judicial sales and in sales requiring judicial assent, the court's discretion is determinative of confirmation of the sale. In this case the authorizing statute provided that the commissioners have the power "with the approval of the Court of Quarter Sessions of the Peace . . . to sell . . . property of the institution district." The statute prescribed no standards to guide the court in giving or withholding its assent to the sale, nor did it prescribe the method to be used in selling the property. Hence there is a sound basis for the Court's holding that assent rested within the discretion of the court in the light of all the circumstances. It is not unreasonable to infer a legislative purpose for subjecting sales of public property to discretionary judicial supervision in order to preclude sales where the circumstances indicate that any irregularity in the conduct of the sale would be difficult or impossible to prove. ${ }^{14}$ On the other hand the Pennsylvania statute for the sale of unused school land requires judicial assent where there is a private sale, but does not require such assent to a sale made at public auction or by sealed bids. ${ }^{15}$ It might be demonstrated, therefore, that this statute shows a legislative purpose of encouraging bidding, and it might be argued that the equity of this statute requires assent to the sale to the highest bona fide bidder in all sales of public land by sealed bid or auction.

Though it be argued that a rule that permits the reopening of bids at the court's discretion negates the efficacy of sealed bids, casts additional and substantial burdens on the already crowded dockets, slows down sales, and relegates the court to an auction house, the fact remains that as in the Coal Land case, the prudent use of this discretion can realize substantial gain for the public. ${ }^{16}$ Moreover, the disadvantages are probably more apparent than real, since the court is constantly called on, and therefore well equipped, to exercise its discretion or opinion in matters of evaluation. If a picayune increase over the high sealed bid is proffered, the court will

regard the subsequent bid in this determination. The court unanimously found the $\$ 177,500$ bid to be unreasonable despite the original belief of the County Commissioners and conflicting evidence of value, the estimates varying from $\$ 93,435$ to $\$ 249,000$.

14. For instance, in the coal land case it was alleged by an unsuccessful bidder at the confirmation hearing that Baton's bid was not delivered by registered mail as required by the terms of sale, but rather was personally handed to the commissioners a few minutes before the time limit, to the alleged prejudice of the other bidders.

15. Pa. Stat. Ann. tit. 24, § 7-707 (Purdon, 1950). In McKees Rocks Borough School District's Petition, 360 Pa. 285, 62 A.2d 20 (1948), it was held that when the court denied assent to a private sale, the court could not direct to whom the property should be sold, but could only direct that the property be re-offered for sale at a price no less than the highest bid received at the private sale.

16. The property was sold to Baton, the appellant, for $\$ 284,000$, or $\$ 106,500$ over the price Baton sought to acquire the property for in the proceedings. 
reject it; if a substantially increased bid is tendered, why deny the benefit of the increase to the public? If, however, the General Assembly feels that the public has more to gain in the long run by giving finality to sealed bids than by the exercise of discretionary judicial assent to sales by auction or sealed bids it should enact appropriate legislation. A uniform policy, one way or the other, would clear up an area of inconsistency and doubt. It should be noted, however, that for the time being it may be to the advantage of the public to retain the rule allowing courts to upset sales on receipt of a higher bid. The national economy is at the present, and probably will be for the next few years, caught in an inflationary spiral. Values, particularly in real estate, have appreciated substantially in short periods of time. Under these circumstances judicial discretion might well be used to bring a higher price for public lands offered for sale where bidders did not accurately foresee the extent of inflationary influences on the value of the realty.

\section{A New Development by Way of Dictum: Allowance to Executors of Counsel Fees for a Will Contest in Pennsylvania}

An executor in Pennsylvania with a will contest in the offing faces the basic problem of whether to attempt to establish the will naming him executor and defend it from attack or withdraw. The answer will generally depend upon whether he will be allowed the costs and counsel fees of the contest, or whether he must pay them himself. The general rule in Pennsylvania has been that an executor has no authority to employ legal counsel at the expense of the estate, and, if he does so, he takes the risks. ${ }^{1}$ This rule has been subject to two exceptions. First, where an executor has been designated or vested with the powers of a trustee, and accepts the trust and is undertaking to carry out its provisions, he owes a duty to the cestuis que trust to uphold the trust in the event of an attack. Thus, if he acted in good faith, regardless of the outcome of the litigation, the court will order reimbursement for his outlay for costs and counsel fees (if there is trust property from which such costs may be paid), or proportional contributions from the cestuis que trust. ${ }^{2}$ The other exception is where an executor has successfully defended the will and the entire estate is benefited, i.e., all those ultimately entitled to share in it. ${ }^{3}$ In such a situation, says the Court, the beneficiaries have benefited by his action, and cannot refuse to reimburse him. ${ }^{4}$ However, counsel fees and costs will not be al-

1. Faust Estate, $364 \mathrm{~Pa} .529,73$ A.2d 369 (1950); Titlow's Estate, $163 \mathrm{~Pa}$. 35, 29 Atl. 758 (1894); Yerkes's Appeal, 99 Pa. 401 (1882) ; Royer's Áppeal, 13 Pa. 569 (1850) ; Fetter's Estate, 151 Pa. Super. 32, 29 A.2d 361 (1942).

2. Lowe's Estate, 326 Pa. 375, 192 Atl. 405 (1937); Mead v. Sherwin, $275 \mathrm{~Pa}$. 146, 118 Atl. 731 (1922).

3. See Alexander's Estate, 211 Pa. 124, 60 At1. 511 (1905) ; Yerkes's Appeal, 99 Pa. 401 (1882) ; Royer's Appeal, 13 Pa. 569 (1850) ; Mumper's Appeal, 3 W. \& S. 441 (1842).

4. Scott's Estate, 9 W. \& S. 98 (Pa. 1845). 
lowed from the estate to a successful executor for seeking to uphold specific bequests in the will, ${ }^{5}$ or where the effect of such an allowance would be to throw a part of the expense on those whose interests were opposed to the course adopted by the executor in sustaining the will, ${ }^{6}$ e.g., where some of the beneficiaries (or cestuis que trust) stood to gain more by a later will, or by intestacy. The rationale behind the rule and its exceptions is that a will contest is viewed as essentially a dispute between only those parties who have a direct pecuniary interest in having that will sustained or set aside, and on general principles of equity each party must bear his own costs individually. ${ }^{7}$ Normally, the executor is not to be prodigal at the expense of those ultimately found to be entitled to the estate. ${ }^{8}$

With this as a background, the court in the recent case of Bennett Estate, $^{9}$ was faced with the following factual situation. A provision in the testator's will read: "It being my wish that . . . he [X] shall not interfere with my executors . . . in their settlement of my estate so given him; as I . . . know they will do the things required of them in the settlement of my estate, in a legal and proper manner, according to law . .." and left the entire estate to $X$ (not of kin). The attorney-executors appointed local counsel and successfully defended the will against an attack by testator's heirs on the ground of $X$ 's undue influence. The executors had notified $X$ that they thought that they bore a duty to defend the will imposed on them by this language of the testator. $X$ objected to the allowance of these costs of contest in the executors' account on the ground that he had not engaged their services, and that by law they were not authorized to employ counsel at the expense of the estate for a will contest. The court found as a fact that $X$ had acquiesced in the executors' efforts on his behalf, declaring that if $X$ disagreed with their interpretation of the will, it was his duty to make known his dissent and engage counsel of his own. It held that since $X$ was liable for the benefit conferred, and was to receive the entire estate, the item of credit for counsel fees would be allowed. While the actual holding is a reaffirmation of the implied contract exception to the general rule, the dictum is quite significant, for the court said it would authorize an executor to employ counsel at the expense of the estate wherever a testator directs or imposes a duty on the executor to defend the will. ${ }^{10}$ This is a new exception to the general rule analogous to the exception in favor of a trustee. Mr. Justice Bell, who dissented to the majority's finding of acquiescence by $X$, nevertheless approved the action of the executors here in defending the will, and stated he would

5. Arnold's Estate, 252 Pa. 298, 197 At1. 415 (1916).

6. Mumper's Estate, 3 W. \& S. 441 (Pa. 1842) ; Rankin's Appeal, 10 W.N.C. 235 (Pa. 1882).

7. See Titlow's Estate, 163 Pa. 35, 29 Atl. 758 (1894); In re Rea's Will, 15 Phila. 578 (1882).

8. See Royer's Appeal, 13 Pa. 589 (1850); Mumper's Appeal, 3 W. \& S. 441 (Pa. 1842) ; Clemens's Estate, 19 Dist. 357 (Pa. 1910).

9. $366 \mathrm{~Pa} .232,77$ A.2d 607 (1951).

10. Id. at 235,77 A.2d at 609 . 
favor the following as an exception to the general rule, viz: "An executor is authorized to defend a will and to employ counsel in a will contest at the expense of the estate, if none of the beneficiaries of the will attempt to defend the will." 11

It is apparent that the dictum of the court, in placing a duty upon the executor to defend a will whenever the testator expressly so directs, opens a new avenue through which executors may be compensated for expenses incident to defense of a will. By this dictum, the court evidently considered the attempted effectuation of the testator's wishes by allowing his executor costs for a will contest at the expense of the estate more desirable than seeing a disposition of testator's property which frustrated his intent because none of the beneficiaries attempted to defend that instrument, or because of agreements inter partes. By suggesting that the executor's defense of the will should no longer be at his own expense, nor contingent on a successful defense of the will which inures to the best interests of all beneficiaries therein, the court would obviously hope to further a disposition of the testator's property in accord with his expressed intention, if the testator so directed, and incidentally, by reason of the financial loss which would be incurred, to perhaps discourage a few would-be-contestants. To allow an executor his costs for a will contest, regardless of the outcome of the litigation, would be tantamount to giving the executor qua executor a personal interest in the estate, and even though good faith $\mathbf{1 2}$ will be required of the executor in his defense of the will, there still remains a likelihood that excessive litigation will be fostered. The objections urged against such a course as proposed by the court are apparent. First, the executor will be allowed to espouse the interests of one set of beneficiaries over another because in many cases some of the beneficiaries under the will would stand to gain more under another will or by intestacy. Second, since the allowance for costs of the executor, will be made from the estate, the successful heirs, in the event the will be found invalid, must be required to pay their opponents' costs. Furthermore, the executor who is also a legatee will be able to further his personal interest at the expense of the other interested parties. However, in striking the balance between delay, expense, and litigation ${ }^{13}$ on one hand and facilitating the disposition

11. Id. at 240,77 A.2d at 611.

12. See e.g. In re Hayer's Estate, 233 Iowa 1343, 11 N.W.2d 593 (1943), and In re Jolly, 3 Wash. 2d 615, 101 P.2d 995 (1940), where the court held that the good faith of the executor is the only requisite for allowing him counsel fees at the expense of the estate.

13. See, for an example of the deleterious effect on the estate, a situation where allowance was made to executors named in the older will for attorneys' fees incurred by them in an unsuccessful resistance to the probate of a later will of the decedent. Re Reimers, 261 N.Y. 337, 185 N.E. 403 (1933) (Counsel fees allowed). Re Reimers, 264 N.Y. 62, 189 N.E. 782 (1934) (Additional allowance sought to cover expenses incurred in defending original order allowing counsel fees. Held, surrogate had power to grant additional allowance). Thereafter, surrogate granted additional allowance, and in $\operatorname{Re}$ Reimers, 268 N.Y. 9, 196 N.E. 619 (1935), it was held that a reversal of the order allowing additional fees was justified, since a substantial allowance had originally been made for the trial and the hearing, and especially so because the size of the estate was such that it was rapidly being eaten up in litigation. 
of the testator's property in accord with his intention on the other, this dictum of the court and the exception of Mr. Justice Bell represent wellreasoned exceptions to the general rule, and a cautious extension of an executor's right to defend the will at the expense of the estate. In the event the court subsequently adheres to this dictum in an actual decision, the executor should be required to apply to the court for an initial determination that the will of the testator directs him to defend it from attack. Making this right dependent upon court approval would have a salutary effect in that subsequent attacks on the good faith of the executor would be barred.

\section{A Debtor Who Can Consume His Own Debt}

Although the rights of life tenant and remainderman in personal property are relatively uncomplicated when the property is put in trust, courts have had considerable difficulty in unraveling their respective rights where the interests created are legal. ${ }^{1}$ This difficulty has been particularly noticeable in Pennsylvania." In this state, the old notion that "a gift or devise of a chattel for an hour is forever" 3 has shown amazing vitality." A long line of cases establishes the proposition that a bequest of personalty for life, without more, passes an absolute estate in the personalty; ${ }^{5}$ the Supreme Court of Pennsylvania was apparently prepared to so hold as recently as $1946 .^{6}$

A situation closely related to that in the above cases arises when a testator makes a bequest to his wife, again for life, but with, in addition, a limitation over of the "surplus," 7 "residue," 8 or "remaining part." 8 "Here too the courts held that the interest in the first taker was absolute, ${ }^{10}$ but

1. Gray, The Rule Against Perpetuities 735 et seq. (4th ed. 1942); 2 Restatement, Property \$200 et seq., Introductory Note $814-819$ (1936); 1 Simes, The Law of Future INTerests 357 et seq. (1936).

2. Brégy, Pennsylvania Intestate, Wills and Estates Acts of 19475953 et seq. (1949).

3. Bro. Abr., Devise, p1. 13 (1576).

4. See Merkel's Appeal, 109 Pa. 235 (1885).

5. E.g., Merkel's Appeal, supra; Rogers' Estate, 245 Pa. 206, 91 Atl. 351 (1914); Drennan's Appeal, 118 Pa. 176 (1888) ; Hartman's Estate, 11 Pa. Super. 35 (1889); Brownfield's Estate, 8 Watts 465 ( $\mathrm{Pa}$. 1839) ; see Freeman's Estate, $220 \mathrm{~Pa}$. 343, 344, 69 Atl. 816 (1908) (addition of "without giving security as life tenant thereof" held to rebut rule of construction.) But cf. Kane's Estate, 6 Pa. Dist. R. 553 (1894) (attempting to distinguish the early cases supporting the rule), affirmed on the facts without opinion, $185 \mathrm{~Pa}$. 544, 40 At1. 90 (1898).

6. See Nelson v. Johnson, $354 \mathrm{~Pa} .512,513,47$ A.2d 650, 651 (1946).

7. Pennock's Estate, $20 \mathrm{~Pa} .268$ (1853).

8. E.g., Markley's Estate, 132 Pa. 352, 19 Atl. 138 (1890) ; Jauretche v. Proctor, $48 \mathrm{~Pa}$. 466 (1865).

9. E.g., Heppenstall's Estate, 144 Pa. 259, 22 Atl. 860 (1891); Gold's Estate, $133 \mathrm{~Pa} .495,19$ Atl. 485 (1890); Reformed Church v. Disbrow, 52 Pa. 219 (1866); see Follweiler's Appeal, $102 \mathrm{~Pa} .581,582$ (1883). See also Boyle v. Boyle, $152 \mathrm{~Pa}$. 108, 25 Atl. 495 (1893) ("any remainder"); Hambright's Appeal, 2 Gr. 320 (Pa. 1855) ("any left").

10. Mercur's Estate, 151 Pa. 49, 24 Atl. 1094 (1892) ; see Follweiler's Appeal, 102 Pa. 581, 583 (1883). 
they restricted its duration to his lifetime. Thus the courts recognized the power of the life tenant to sell or otherwise dispose of the property during his life, but they specifically denied him the power to pass any remaining portion by his will.11 That which remained passed under testator's will, apparently by executory limitation. ${ }^{12}$ In such cases, there was no requirement that security be entered for the protection of the remaindermen, since they were entitled only to what was left. ${ }^{13}$

In Holman's Appeal, ${ }^{14}$ one of the early cases belonging to the latter group, the court expanded its views on the status of the life tenant. It declared that "a life tenant who has the usufruct of a totality of goods has the right to use and enjoy them according to their nature." The personal property involved in that case consisted of animals, furniture, farming implements, and grain-all of which fall under the head of things quae ipso usu consumuntur-and the court accordingly held that the widow could consume the personalty without incurring liability. However, the court went on to distinguish gifts of money on the ground that "money is not necessarily impaired by use because the use of money is no more than the interest or dividends which may be enjoyed by the usufruct without diminishing the principal." 15 Where, therefore, there was a gift of money for life, security was required from the first legatee. ${ }^{16}$

The early rules as to the requirement of security where personal property was given for life subject to a future interest were codified by the Act of $1834^{17}$ which, with minor changes, was reenacted by subsequent statutes. $^{18}$ These statutes do not purport to alter the substantive law as to the

11. Cf. Markley's Estate, 132 Pa. 352, 19 Atl. 138 (1890) ; Lininger's Estate, 110 Pa. 398, 1 Atl. 722 (1885). And see Welsh's Estate, 239 Pa. 616, 618, 86 Atl. 1091, 1092 (1913).

12. In England, where personalty is bequeathed to one for life with a limitation over, the life tenant takes an absolute interest subject to an executory limitation. GrAx, op. cit. supra note 1 , at $740-743$. This rule developed by an analogy to Manning's Case, 8 Co. Rep. $94 \mathrm{~b}$ (C. P. 1609), which involves a bequest of similar interests in chattels real. See 1 FEarne, Contingent Remainders 402 (10th ed., Butler 1844). The early Pennsylvania cases considered limitations over after a life estate in personalty to be executory bequests. Eichelberger v. Barnetz, $17 \mathrm{~S}$. \& R. 293 (Pa. 1828). BRÉGY, op. cit. sipra note 2, at 5955n. states that such an interest was held to be a contingent remainder in Reiff's Appeal, $124 \mathrm{~Pa}$. 145, 16 Atl. 636 (1889), but this is not clear from the case, which merely says that the interest is contingent for the purpose of transmissability. The present state of the law is somewhat confused. For the purpose of this Note the parties will be referred to as life tenant and remainderman throughout.

13. E.g., Heppenstall's Estate, 144 Pa. 259, 22 Atl. 860 (1891) ; Kinnard v. Kinnard, 5 Watts 108 (Pa. 1836). See also Powell's Estate, 340 Pa. 404, 17 A.2d 391 (1941).

14. $24 \mathrm{~Pa} .174$ (1854).

15. Id., at 178 .

16. Kinnard v. Kinnard, 5 Watts 108 (Pa. 1836). Contra: Hambright's Appeal, $2 \mathrm{Gr} .320$ ( $\mathrm{Pa} .1855$ ) ( $\$ 3000$ to my wife and if any is left at her death, over).

17. Act of February 24, 1834, P.L. 73.

18. Act of April 17, 1869, P. L. 70; Act of May 17, 1871, P. L. 269; Act of June 7,1917, P. L. 447. Section 23 of the latter act provides: "Whenever . . . any personal property, or the increase, profits or dividends thereof, has been or shall hereafter be bequeathed to any person for life or for a term of years or for any other limited period, or upon a condition or contingency; the executor . . . shall deliver 
relationships created; they simply require the entry of security in all cases. ${ }^{19}$ The problem is: security for what? If the property subject to the future interest is consumable, it would be absurd to require security for something to which the remainderman might never be entitled. It was therefore held in Hambright's Appeal ${ }^{20}$ that, under these circumstances, no security was necessary. Where, however, the property would be delivered intact, security could be required, ${ }^{21}$ and the amount of that security would be based on the value of the property at the time of delivery to the first taker. ${ }^{22}$ In the case of money, a further difficulty was presented. Since money was property not necessarily impaired by use, it fell in the latter category, and security had to be entered. ${ }^{23}$ However, to require the life tenant to hand the same money over to the remainderman would be to deny him the use of the property. This problem was presented in Reiff's Appeal, ${ }^{24}$ and the court in attempting to resolve the dilemma, resorted to the familiar device of holding the interest in the first taker absolute, ${ }^{25}$ saying "the money became essentially her own; and she was simply a debtor to the parties ultimately entitled at her death. .. The remaindermen are now creditors." 28

The theory first enunciated in Reiff's Appeal was crystallized into a rule of law by Letterle's Estate ${ }^{27}$ and subsequent cases. ${ }^{28}$ As developed, the rule may be stated as follows: where there is a gift of a fund for life without the creation of a trust, the life tenant will be regarded as a debtor to the remainderman for the cash value of the assets distributed to him. Thus, where the original assets are retained and increase in value during the first taker's life, the life tenant may keep the excess over the original

the property so bequeathed to the person entitled thereto, upon such person giving security in the Orphans' Court having jurisdiction, in such form and amount as in the judgment of the court will sufficiently secure the interest of the person or persons entitled in remainder, whenever the same shall accrue or vest in possession. Should such person or legatee refuse or neglect, or be unable to enter such security, the court may, upon petition of any person interested ... appoint a suitable person or corporation as trustee. . . . Such trustee shall enter such security as the court may direct. He shall not be an insurer of the trust fund, and shall be liable to the persons interested in the income or corpus of the trust fund only for such care, prudence and diligence in the execution of the trust as other trustees are liable for."

19. See BRÉGX, op. cit. supra note 2, at 5956.

20. $2 \mathrm{Gr}$. 320 (Pa. 1855). Although the property involved was money, it was specifically made consumable. See also Heppenstall's Estate, $144 \mathrm{~Pa}$. 259, 22 At1. 860 (1891); Straub's Appeal, 1 Pa. 86 (1845); Metz' Estate, 323 Pa. 241, 195 Atl. 740 (1936); Powell's Estate, 340 Pa. 404, 17 A.2d 391 (1944).

21. Dewey's Estate, 33 Pa. Co. Ct. R. 307 (1905) (realty); Van Dusen's Estate, 11 W.N. Cases 481 ( $\mathrm{Pa}$. 1882) (corporate stock).

22. See note 18 supra.

23. Kinnard v. Kinnard, 5 Watts 108 (Pa. 1836).

24. $124 \mathrm{~Pa}$. 145,16 Atl. 636 (1889).

25. See Clevenstine's Appeal, 15 Pa. 495 (1850); Hartman's Estate, $11 \mathrm{~Pa}$ Super. 35 (1899).

26. Reiff's Appeal, 124 Pa. 145, 16 Atl. 636 (1889).

27. 248 Pa. 95, 93 At1. 935 (1915).

28. E.g., Kirkpatrick's Estate, 284 Pa. 583, 131 At1. 361 (1925) ; Gillett's Estate, $130 \mathrm{~Pa}$. Super. 309, 197 Atl. 517 (1938); Strawbridge's Estate, 14 Pa. D. \& C. 703 (O.C. Phila. 1931); Russ' Estate, 18 Pa. D. \& C. 412 (O.C. Elk 1932) ; Clark's Estate, 66 Montg. County, L. Rep. 285 (Pa. 1950). 
value, ${ }^{29}$ but, where the value of the assets depreciates, the loss must be made up from his own estate. ${ }^{30}$ The rule has even been held to apply where the life tenant has a power of consumption, to the extent that the property remains unconsumed. ${ }^{31}$ In this and other respects, the original close relation to the statutory requirement of security has been abandoned. ${ }^{32}$ Where a fund is involved, unless the language of the will can be interpreted as creating a trust, ${ }^{33}$ the life tenant is virtually trapped. His only means of escape is to refuse to enter security and petition the court to appoint a trustee for the fund. ${ }^{34}$

The soundness of the extension of the debtor-creditor theory to life estates with power to consume was recently challenged in Lyman's Estate, $366 \mathrm{~Pa} .164,76$ A.2d 633 (1950). In that case, testator devised and bequeathed the residue of his estate, both real and personal, to "my dear wife ... for and during the term of her natural life, with full power and authority to use so much of my residuary estate, from time to time as may be necessary for her support and maintenance, should the income therefrom prove insufficient ... and ... all the rest, residue and remainder of my said residuary estate, real, and personal, that may be left at the time of her decease" to seven named relatives and a charity. During her life the widow consumed a portion of the personalty. The remainder, which consisted chiefly of securities, ${ }^{35}$ she kept separate from her own property, retaining the same investments which her husband had made. These securities depreciated considerably in value, and the remaindermen demanded that the loss be made up from the widow's estate. Logically, there is no distinction between the language of the will in the instant case and the language of the wills in the two preceding cases involving life estates with

29. E.g., Letterle's Estate, 248 Pa. 95 (1915); Kirkpatrick's Estate, supra; Clark's Estate, supra.

30. Gillett's Estate, $130 \mathrm{~Pa}$. Super. 309, 197 At1. 517 (1938) ; Strawbridge's Estate, 14 Pa. D. \& C. 703 (O.C. Phila. 1931). No direct holding by the Supreme Court that the life tenant's estate must pay over to the remainderman the amount of the loss has been found.

31. Hays' Estate, 358 Pa. 43, 55 A.2d 763 (1947) ; Powell's Estate, 340 Pa. 404, 17 A.2d 391 (1941). Contra: 'Metz' Estate, 323 Pa. 241, 185 Atl. 740 (1936); Tyson's Estate, 191 Pa. 218, 43 Atl. 131 (1899).

32. See Kirkpatrick's Estate, $284 \mathrm{~Pa}$. 583, 131 At1. 361 (1925) (entry of security by life tenant excused by the will); Gillett's Estate, 130 Pa. Super. 309, 197 Atl. 517 (1938) (life tenant neglected to put up bond).

33. Erdman's Estate, 352 Pa. 158, 42 A.2d 546 (1945); DuPuy's Estate, 346 Pa. 138, 29 A.2d 527 (1943).

34. In Weir's Estate, 251 Pa. 499, 96 Atl. 1086 (1916), the trustee who replaced the life tenant found himself in an unfortunate position as a result of the life tenant's refusal to enter security. The court there held that he stood in the place of the life tenant and had to account for the cash value of the trust res. This interesting doctrine was nipped in the bud by the Act of 1917's provision that the trustee should not be deemed an insurer of the trust fund. See note 18 supra. See also Printzenhoff's Estate, 10 Pa. D. \& C. 335 (O.C. Phila. 1918). The act was not, however, retroactive, and the courts were compelled to go through considerable verbal gymnastics to reach the statutory result in cases involving wills taking effect prior to the statute. See Loewer's Estate, 263 Pa. 517, 106 Atl. 789 (1919); Ertel's Estate, 19 Pa. D. \& C. 95 (O.C. Phila. 1932).

35. Record $24 a$. 
power to consume. ${ }^{36}$ Yet the Supreme Court of Pennsylvania held, on appeal, that because of the intent of the testator no debtor-creditor relationship arose.

No matter how much the result reached in the particular case may be commended, the court's reasoning leaves much to be desired. The court declared that "testator cannot ... be presumed to have intended to impose a legal liability on his wife, as life tenant, which extant rules of construction did not then impose on the character of life estate which he bequeathed." 37 To say that testator in 1928 anticipated and intended to avoid a rule of construction first enunciated in 1941 is to credit him with more precognition than the then Supreme Court of Pennsylvania. Furthermore, the court also found that the wife was the primary object of testator's bounty from the reference to her in the will as "my dear wife." 38 The inclusion of terms of endearment in describing a legatee may well be merely scriviner's language, ${ }^{39}$ and at any rate is not intended to affect the legal consequences of the disposition. ${ }^{40}$ Much confusion and speculation among lawyers would have been avoided if the court had undertaken a re-examination of the principles underlying the debtor-creditor theory, as applied both to life estates with power to consume and in general.

In the early cases dealing with consumable tangible property, there is no suggestion that the remainderman would be entitled to anything more than what was physically left over. ${ }^{41}$ As late as 1936, the cases involving life estates in money with power to consume followed the same general pattern. ${ }^{42}$ The basic assumption in both groups of cases was that there was specific personal property which might be consumed by the life tenant.

36. See Brief for Appellees, pp. 7-11, setting forth the wills in Hays' Estate, 358 Pa. 38, 55 A.2d 763 (1947) and Powell's Estate, 340 Pa. 404, 17 A.2d 391 (1941) in parallel columns with the will in Lyman's Estate. As the brief comments, no mediaeval scholastic could differentiate between the expressions used.

37. Instant case at 169. Query what effect this has on stare decisis. The will in Powell's Estate, supra took effect in 1904, only five years after the decision in Tyson's Estate, 191 Pa. 218, 43 Atl. 131 (1899). Similarly, the will in Hays' Estate, supra took effect in 1939, between Metz' Estate, 323, Pa. 241, $185 \mathrm{~Pa} .740$ (1936) and Powell's Estate.

38. Instant case at 170. Query how much more indicative this is of affection than "to my beloved wife," which appears in Powell's Estate, supra. Perhaps, as the court seems to say, repetition makes the heart grow fonder.

39. See 2 DunlaP, Book of Forms, 2759-2789 (8th ed. 1930). Although the phrase "to my dear wife" occurs only once, "to my beloved wife" appears in an overwhelming majority of the specimen forms. In the only specimen involving a bequest to a mother, she is referred to as "honored mother." Id. at 2781.

40. The significance of these words has been discussed with members of the faculty of the Law School and with members of the Philadelphia Bar. There was some disagreement as to whether the use of words of endearment is merely the survival of a ritualistic archaism or whether it is done at the request of the testator. All are agreed, however, that the fact that such words are omitted (as they are in most modern wills) does not indicate lack of testamentary affection. See Will of Kendrick, 210 Wis. $218,221,246$ N.W. 306, 307 (1933) : "as stated, the trial court attached some importance to the fact that the testatrix did not refer to the appellant in her will as her beloved husband. . . W We find no evidence of a lack of affection. ..."

41. See Holman's Appeal, $24 \mathrm{~Pa} .174,178$ (1854); Markley's Estate, $132 \mathrm{~Pa}$. 352, 19 At1. 138 (1890).

42. Metz' Estate, $323 \mathrm{~Pa}$. 241, 185 Atl. 740 (1936); Tyson's Estate, $191 \mathrm{~Pa}$ 218, 43 Atl. 131 (1899). See Watson's Estate, 241 Pa. 271, 88 At1. 433 (1913). 
Yet in 1941 the Supreme Court, in Pozell's Estate, declared that the debtor-creditor theory applies to life estates with power to consume. ${ }^{43}$ This declaration was reaffirmed in Hays Estate, where it was held that the remaindermen had no interest in accretions to the principal.44 In so extending the debtor-creditor theory, the court seems to have ignored the logical inconsistency between a power to consume specific property and the loss of identity of the specific property on which the debtor-creditor theory is predicated. ${ }^{45}$ The result is to make the life tenant's power a power to consume not the property bequeathed, which has theoretically been merged into his estate, but rather his own debt to the remainderman. ${ }^{46}$ A further paradox arises from the fact that, if the conditions which the debtor-creditor theory was designed to meet occur, and the property completely loses its identity, the remainderman will take nothing because there is a presumption of consumption. ${ }^{47}$ Thus the debtor-creditor theory can be effectively invoked only when the specific property can be traced, in which event there is no real need for it. It is submitted that the giving of a power of consumption is in itself sufficient evidence that the testator does not intend to surcharge the life tenant for losses from principal and that, therefore, the debtor-creditor theory should never be applied in a situation such as that presented in Lyman's Estate.

At the same time, it would seem that the basis of the whole debtorcreditor theory is in need of reexamination. The dictum in Holman's Appeal that money is not necessarily impaired by use may have been reasonably accurate when viewed in the economic milieu of the 1850's. During that time, there was a gradual but nonetheless continuous inflation of prices and property values generally. ${ }^{48}$ Then the standard investments were in government bonds and real estate mortgages. ${ }^{49}$ A man could therefore have the use of his money without running a serious risk of impairing the monetary value of the principal. Today, however, conditions are not

43. 340 Pa. 404, 17 A.2d 391 (1941).

44. $358 \mathrm{~Pa} .38,40,55$ A.2d 763, 764 (1947).

45. See BrÉGX, op. cit. supra note 2 , at 5961.

46. 96 U. of PA. L. REv. 571, 572 (1948).

47. Richey's Estate, 251 Pa. 324, 96 Atl. 748 (1916); Welsh's Estate, $239 \mathrm{~Pa}$. 616, 619, 86 Atl. 1091, 1092 (1913).

48. See Historical Statistics of the United States 1789-1945 232 (U.S. Dep't Comm., Bureau of the Census 1949). The belief that prices will remain stable over a long period of time seems to persist in judicial and legislative thinking. Compare the investments sanctioned by The Fiduciaries Investment Act of 1949, Pa. Stat. ANN., tit. 20, $\$ 821$ (Purdon, 1950) with those suggested in Dowre AND Fuller, Investments 119-135 (2d ed. 1950).

49. See Act of February 18, 1824, P.L. 25, which specifically limited investments by trustees and other fiduciaries to state and national government securities and first mortgages on real estate. While such limitations would not apply to funds not held in trust, the tendency was for those more interested in preserving their principal than in speculation to employ the same types of investments. See KIRSHMAN. Principles of Investment 29 (2d ed. 1933). And see Gunther, Inside U.S.A. 606 (1947): "The trustees of Philadelphia, like those of Boston, invested the old family fortunes with extreme conservatism. . . The basis of the ancient wealth was real estate; a sound mortgage was venerated in Philadelphia practically on the same level as the Episcopal church." 
the same. The modern tendency ${ }^{50}$ is to invest in common stock, whose value fluctuates daily. ${ }^{51}$ A bona fide attempt to get the full use or interest on money almost inevitably forces the investor to take the risk of depreciation in value. To mulct a life tenant in damages for taking such a risk is to deny him the usufruct to which Holman's Appeal insists he is entitled.

The unsatisfactory results engendered by the dictum in Holman's Appeal have been recognized in the change in the law of future interests made by the Estates Act of 1947.52 Section 13 of that act abolishes for the future the debtor-creditor theory and substitutes in all cases of legal life estates in personalty a trust relation by operation of law. ${ }^{53}$ The thrust of such a basic change in the law is this: when all the technicalities of language are stripped away, what a man intends to do when he leaves personal property to one person for life and then to another is to give them interests in that mass of property, and not in its value in dollars and cents. ${ }^{54}$ If the remainderman gets that mass, either in specie, or in what it has become, he is getting all the testator meant him to get. On the other hand, the life tenant is in almost every case the primary object of testator's bounty and should get the mass to use freely without running the risk of losing his own property because of circumstances beyond his control. Such an interpretation, it is submitted, is fairer to the legatees and far more in conformity with testator's true intent than the creation of a fictitious debtorcreditor relationship under an arbitrary and outmoded rule of construction.

\section{Trusts-Inter Vivos or Testamentary? For What Purpose?}

When the owner of property creates a trust during his life and reserves a measure of control over or enjoyment in the trust property, the courts often find it important to determine whether the trust is valid "inter vivos" or is merely "testamentary." The distinction is important

50. Both to obtain a higher current income and to hedge against the economic fact of inflation. See SmIte, Common Stocks As Long Term Investarents (1929).

51. See DowrIe AND FULIER, op. cit. supra note 49, at 119-135.

52. Act of April 24, 1947, P. L. 100, PA. STat. Ann., tit. 20, §301 (Purdon, 1950). Note also the agreement between the life tenant and the remaindermen that the life tenant should not be liable for depreciation in Clark's Estate, 66 Montg. County L. Rep. 285, 287 ( $\mathrm{Pa}$. 1950).

53. "A person having a present interest in personal property, or in the proceeds of the conversion of real estate, which is not in trust, and which is subject to a future interest, shall be deemed to be a trustee of such property, and not a debtor to the remainderman, with the ordinary powers and duties of a trustee, except that he shall not be required to change the form of investment to an investment authorized for Pennsylvania fiduciaries, nor shall he be entitled to compensation as trustee. Such person, unless given a power of consumption or excused from entering security by the terms of the conveyance, shall be required to enter such security for the protection of persons entitled to the future interests as the court in its discretion shall direct. If a person having a present interest shall not enter security as directed, the court shall appoint a trustee who shall enter such security as the court shall direct, and who shall exercise all the ordinary powers and duties of a trustee, except that he shall not be required to change the form of the investment to an investment authorized for Pennsylvania fiduciaries." PA. STAt. ANN., tit. 20, §301.13 (Purdon, 1950).

54. See BREGY, op. cit. supra note 2, at 5963 . 
for purposes of determining whether the res of the trust is subject to the state inheritance tax at the settlor's death, or reachable by the settlor's creditors, or by his surviving spouse exercising a statutory right of election. It is also important for purposes of determining whether the beneficiaries of the trust or the settlor's heirs or residuary legatees should take the trust property at the settlor's death. The question of how much interest in the trust property the settlor can retain and avoid the consequences of the trust being treated as "testamentary" is necessarily a matter of degree and varies, to some extent, with how the question comes up. The conventional statement of the rule, adopted by the Pennsylvania courts, is that a trust will not be treated as "testamentary" for most purposes merely because the settlor has reserved a life estate in himself, ${ }_{1}^{1}$ or the power to revoke, ${ }^{2}$ or both. ${ }^{3}$ The test it is said, is whether the settlor has reserved so much power of control over the details of the administration of the trust as to constitute the trustee the mere agent of the settlor. If he has, the trust is "testamentary" for all purposes. ${ }^{4}$

A recent Pennsylvania case raises the question of whether the "agency" test should be utilized in cases where the residuary legatee of the settlor is contesting the trust-beneficiary's right to the trust property. In Sheasley's Trust ${ }^{5}$ the settlor reserved a life estate in the income from the trust property as well as the right "to manage, lease, sell or otherwise dispose of any or all (of the trust property) and receive the entire income of the proceeds." 6 Irrespective of the extent of the powers reserved, the court nevertheless concluded that the trust was not "testamentary," putting great emphasis on the fact that it was created by a formal deed. ${ }^{7}$ If this

1. Windolph v. Girard Trust Co., $245 \mathrm{~Pa} .349,368,91$ At1. 634, 640 (1914).

2. Dickerson's Appeal, 115 Pa. 198, 210, 8 Atl. 64, 69 (1886).

3. Beirne v. Continental Equitable Title \& Trust Co., 307 Pa. 570, 576, 161 At1. 721, 722 (1932); Shapley's Trust, 353 Pa. 499, 46 A.2d 227 (1946); Restatenent, TRUSTS $\$ 57$ (1934); SCOTT, TRUSTS \$330.11 (1939).

4. Tunnel's Estate, $325 \mathrm{~Pa}$. 554, 190 Atl. 906 (1937).

5. 77 A.2d 448 (Pa. Sup. Ct. 1950).

6. Instant case at 450 . The facts of this case are extremely complicated. Jacob Sheasley deeded some real estate to two of his sons for a stated consideration of $\$ 20,000$. Contemporaneously therewith the sons declared themselves trustees of the real estate for their father, granting him the broad powers outlined above. Though it would thus appear that the sons were the settlors and the father the beneficiary, the court ignored the form of the transaction and treated Jacob Sheasley as the actual settlor. After the above transaction $X$, one of the beneficiaries of the trust who was also a residuary legatee under Jacob Sheasley's will, assigned to $Y$ all his interest in any property received under Jacob Sheasley's will. $Y$ argued that since the trust was "testamentary" in character $X$ received the property under the residuary clause of the will and not as the beneficiary of a valid inter vivos trust. The situation can thus be treated analytically as one where the residuary legatee is contesting with the trust beneficiary over the validity of the inter vivos trust.

7. The court relied heavily on the presence of a deed in the instant case to distinguish it from Tunnel's Estate, supra note 4. In the latter case the settlor constituted himself trustee of certain bonds for his children by a signed memo and reserved to himself the right to all "sell, transfer and assign the bonds at any time to any person" (325 Pa. at $557190 \mathrm{At1}$. at 908). The court said that the trust was "testamentary" for purposes of the settlor's heirs taking rather than the beneficiaries of the trust. Regardless of whether or not the above reservations in fact constituted the trustee the mere agent of the settlor, it is evident that the settlor in Sheasley's case reserved much greater powers and that if Tunnel's Estate was law, 
decision is to be taken at face value in subsequent cases, it may represent a retreat from the "agency" test in determining whether or not the power reserved by the settlor makes a trust created in his life "testamentary." It is thus appropriate to review the problems created by questionable inter vivos trusts in Pennsylvania to determine whether or not that test is of service in solving those problems. Such a review will indicate, it is submitted, that the agency test fails to meet the real issues created by these trusts.

1. Taxation-In cases involving inheritance taxes the court early recognized that there was a conflict between strict trust principles and taxation policy. 8 If all inter vivos trusts short of those wherein the trustee was the "agent" of the settlor were non-taxable, the entire consequences of the Inheritance Tax could be avoided and the enjoyment of the property retained by the settlor, simply by creating a revocable trust with a lifeestate in the settlor. Accordingly, the court, for the most part, abandoned the "agency" test saying that the policy of the Inheritance Tax requires the taxing of any trust wherein the settlor has not in fact divested himself of the enjoyment of his property prior to his death. ${ }^{9}$ Thus, it has been held that where the settlor reserves a life estate, the res of the trust is includible in his gross estate for purposes of computing his inheritance tax, regardless of whether the deed of trust is revocable ${ }^{10}$ or irrevocable. ${ }^{11}$ The court's perception in tax cases has enabled it to see through the legal sleight-of-hand whereby the actual transferor of the property has attempted to pose as a beneficiary of a trust purportedly created by the transferee. In such cases they have held the res of the trust taxable at the transferorbeneficiary's death. ${ }^{12}$ Even in inheritance tax cases, however, the ghost of

Sheasfey's trust would be "testamentary." The court in Sheasley's case found a "distinction" between the two cases on the grounds that Sheasley's trust was created by a formal deed, citing the last paragraph of comment $G$ of section 57 of the $R e-$ statement as authority for such a distinction. This passage simply states that one of the factors to be considered in determining whether or not the trustee is the settlor's agent is the formality of the transaction. It does not state that where the trust is created by deed the agency test is to be abandoned.

8. The test for taxation purposes was thus stated in Glosser's Trust, $355 \mathrm{~Pa}$. 210, 215, 49 A.2d 401, 404 (1946); "The criterion is not whether the beneficiaries are to acquire actual possession or enjoyment at or after the death of the donor, but whether the latter has irrevocably parted with all his interest, title, possession and enjoyment in his lifetime." In Lines Estate, $155 \mathrm{~Pa} .378,26$ At1. 728 (1893) the court held the collateral inheritance tax of 1887 applicable to the res of a trust wherein the settlor had reserved a life estate and the power to revoke, despite the fact that the same court had previously held the same trust not "testamentary" for purposes of the widow's right of election-Lines v. Lines, $142 \mathrm{~Pa}$. 149, 21 Atl. 809 (1891).

9. Lines Estate, supra note 8, Jones Estate, $350 \mathrm{~Pa}$. 120, 38 A.2d 30 (1944), Glosser's Trust supra note 8; Todd's Trust, $358 \mathrm{~Pa}$. 530, 58 A.2d. 135 (1948).

10. Lines Estate, supra note 8; Todd's Trust, supra note 9.

11. Jones Estate, supra note 9; Husbands Estate, 304 Pa. 235, 155 Atl. 605 (1931) ; Cooper's Estate, $320 \mathrm{~Pa}$. 414, 183 At1. 45 (1936).

12. In Jones Estate, supra note $9, \mathrm{~A}, \mathrm{~B}$ and $\mathrm{C}$ executed with a common trustee similar deeds of trust, "the effect of which transaction was to secure each of the settlors income for their respective lives, - with remainder to their respective heirsat-law, of property in amount and character identical with that conveyed."

It was consequently held that all three trusts were taxable. The fact that none of the settlors formally reserved a life-estate in the property then conveyed to the trustee was said to be immaterial. 
the "agency" principle has not been entirely laid. When the trust is merely revocable and no life estate is reserved to the settlor, the court has held that the res of the trust is not taxable at the settlor's death unless the trust is invalid under the "agency" test. ${ }^{13}$ It is not without significance that in the principal Pennsylvania case holding merely revocable trusts non-taxable, the court abandoned the test of whether the settlor had completely divested himself of his property prior to death, and concerned itself with whether or not the trust was "testamentary" in the abstract, citing entirely inapposite cases to prove that it was not. ${ }^{14}$ On the verbal level it is difficult to see why an irrevocable trust with a life estate in the settlor is any more "testamentary" than a trust which can be partially or wholly revoked at the settlor's discretion. In the first case, the settlor has totally divested himself of control over the res of the trust yet the res is taxed at his death. ${ }^{15}$ In the second case the settlor has retained the right to control the res at any time during his life, yet the res is not taxable at his death. ${ }^{16}$ From the point of view of the purposes of the Inheritance Tax statute it would seem that in both cases the res should be taxable because in neither case has the settlor parted with actual or potential beneficial enjoyment of the property prior to his death. ${ }^{\mathbf{1 7}}$ This principle was recognized by the United States Congress which simply declared that revocable trusts were taxable at the settlor's death. ${ }^{18}$ The conclusion to be drawn from an analysis of the Pennsylvania decisions dealing with the taxation aspect of revocable trusts is that the "agency" test has never been particularly helpful in determining whether or not a given trust should be taxable; and when the courts have reverted to it, inequities have resulted.18

2. Election-One of the most frequently litigated questions concerning trusts where the settlor reserves power of control or enjoyment, is whether they are "testamentary" for the purposes of the surviving spouse's statutory right of election to take against the deceased spouse's will. ${ }^{20}$ An

13. Dolan's Estate, 279 Pa. 582, 124 Atl. 176 (1924).

14. Id. at 580,124 Atl. at 178, 179. The cases cited by the court to sustain the holding that a merely revocable trust was not taxable, were mostly cases holding that a revocable trust was not "testamentary" for the purposes of the wife taking against the will, i.e. Dickerson's Appeal $115 \mathrm{~Pa}$. 198, 8 Atl. 64 (1886); Lines v. Lines, $142 \mathrm{~Pa}$. 149, 21 At1. 809 (1891); Windolph v. Girard Trust Co., $245 \mathrm{~Pa}$. 349, 9 At1. 634 (1914). It is interesting to note that although the court cites Lines v. Lines, the case holding that the widow couldn't take against the res of that trust, it fails to cite Lines Estate, supra note 8, which held the very same trust taxable. The language and approach of the court in the Dolan case should be compared with the language and approach of the court in Glosser's Trust, supra note 8.

15. Jones Estate, $350 \mathrm{~Pa}$. 120, 38 A.2d 30 (1944).

16. Dolan's Estate, supra note 13.

17. Glosser's trust, supra note 8.

18. See Int. Rev. Code, 26 U.S.C. §811(d) $(1,2)$ (1946).

19. The RESTATEMENT of TRUSTs implies that the agency principle is not applicable to the tax situation. RESTATEMENT, TRUST $\$ 57$, comment e (1934).

20 . As early as 1848 the Pennsylvania legislature recognized the inadequacy of the protection afforded by dower and curtesy and gave the surviving spouse the right to take against the deceased spouse's will as to personal as well as real property P.L. $536 \S 11$ (1848). 
early device used to frustrate the policy of the election statutes was the creation by a discontented spouse of a revocable trust with a life estate in himself and remainder to beneficiaries other than the surviving spouse. Had the judges felt as strongly about the policy of the election statute as they did about the taxation statute, they might have reasoned similarly and held that such patent attempts to frustrate the policy of the act would not be tolerated. Despite some strong dissents in favor of the neglected spouse, ${ }^{21}$ however, the court consistently held that the settlor could denude his estate by such a trust, leaving his spouse both penniless and remediless, provided only that he did not reserve so much power over the res as to constitute the trustee his mere "agent." 22 By the Estates Act of 1947 the surviving spouse is given the right to treat as "testamentary" any transfer of assets wherein the deceased spouse reserves the right to revoke or appoint by will.23 Only recently the Supreme Court has held that this Act does not apply to revocable trusts created prior to its passage. ${ }^{24}$ It is submitted that the "agency" test was never really applicable to this field and that the new legislation will produce more desirable results than those produced by a strict application of trust principles to these problems.

3. Creditors' Rights-Where the settlor has reserved a life estate in the res of the trust, there is no doubt that his creditors can reach that interest while he is alive. ${ }^{25}$ It is much more questionable whether the settlor's creditors can reach his power to revoke. Aside from conveyances in fraud of existing or prospective creditors, ${ }^{26}$ the rule is that the res of a revocable trust cannot be reached by a settlor's creditors during his life, or at his death unless the settlor has reserved so much power of control over the res as to constitute the trustee his mere agent. ${ }^{27}$ Historically, the reasoning behind this result has been a restatement of the conclusionthe power to revoke is purely personal to the settlor; dies with him and, therefore, cannot be reached by his creditors during his life or at his death. ${ }^{28}$ Practically, the result has been justified by some on the ground that equity has a stronger interest in protecting the settlor's dependent

21. Notably that by Justice Kephart in Beirne v. Cont. Equitable T. \& Tr. Co., $307 \mathrm{~Pa} .570$, 579-92, 161 Atl. 721, 723-728 (1932).

22 . In Lines v. Lines, supra note 8 , the court said: "It is the settled law of this state that a man may beggar himself and his family. . . When he dies, and then only, do the rights of his wife attach to his personal estate." (142 $\mathrm{Pa}$. at 165,21 Atl. at 810 ). See also; Dickerson's appeal, supra note 2; Windolph v. Girard Trust Co., supra note 1.

23. Pa. Stat. Ann. Tit. 20 \& 301.11 (Purdon 1947).

24. In re McKean's Trust Estate, 77 A.2d $447^{\circ}$ ( $\mathrm{Pa}$. 1951).

25. In Pennsylvania attachment will lie against a beneficiary to garnish trust property in the trustee's hands. Smeltzer v. Goslee, $172 \mathrm{~Pa}$. 298, 34 At1. 44 (1896).

26. Such conveyances are governed by the Uniform Fraudulent Conveyances Act,

Pa. Star. Ann. Trt. 39, \$356-363 (Purdon 1921).

27. See: Fidelity Trust Co. v. Union National Bank of Pittsburgh, 313 P.A. 467, 489, 169 Atl. 209. 216 (1934); Kenin's Estate (No. 1) 343 Pa. 549. 23 A.2d 837 (1942); Restatenent, Trusts $\$ 380$. Comment O (1934).

28. See note 27, supra. Also see Dolan's Estate, supra note 13; III Scort TRUSTS, § 330.12 (1939). 
beneficiaries than in protecting his creditors. ${ }^{29}$ It is submitted that the solicitude which exempts the entire res of a revocable trust from creditors' claims is often unwarranted. In the first place it might be suggested that in Pennsylvania the dependent relatives may be adequately taken care of by statutes which exempt from the claims of creditors the proceeds of life insurance policies, whether in trust or not, when payable to the settlor's dependent relatives. ${ }^{30}$ Furthermore, if the real reason for holding revocable trusts unreachable by the settlor's creditors is to take care of the needs of dependent relatives, it would be both more realistic and more equitable to state that result in terms of a preferment of the dependent relatives over the general creditors, allowing the courts an opportunity at least of giving the creditors something of the res after the dependent relatives are provided for. The fact which the usual statement of trust principles will not permit of recognition is that the power of revocation is a potential asset always capable of producing real assets. Some jurisdictions, notably New York and the federal courts in bankruptcy cases, recognize this fact and give the creditors or their representatives the right to reach the res of the trust. $^{31}$ Thus far Pennsylvania has rested with the "agency" test. ${ }^{32}$

4. Statute of Wills. In cases where the issue is between the beneficiaries of the trust and the settlor's residuary legatees or next-of-kin, the only important policy involved is that of the statute of wills. Here the agency test is applied and produces some other anomalous results from the standpoint of the policy of that act. . $^{33}$ By concentrating attention on whether or not the trustee is the agent of the settlor, rather than on whether

29. See: Provident Trust Co. v. Rothman, 321 Pa. 172, 185, 183 Atl. 793, 796 (1936) ; Stutzman v. Fidelity Ins. Co., 315 Pa. 147, 149, 172 At1. 302, 303 (1934); Potter Title \& Trust Co. v. Fidelity Trust Co., $316 \mathrm{~Pa} .316,317,175$ Atl. 400, 401 (1934).

30. PA. Stat. Ans. tit. 40, $\$ 517$ (Purdon 1932). As to when the changing of the beneficiary of a life insurance policy may be a fraud on creditors, see Cohen, The Frandulent Transfer of Life Insurance Policies, 88 U. of PA. L. REv. 771 (May 1940).

31. Under the National Bankruptcy \$70a (3) 11 U.S.C. \$110 (1946) all powers which the bankrupt might have exercised for his own benefit can be reached by the trustee in bankruptcy including the power of revocation of a trust created by him. In New York it is provided that, "where the grantor reserves ... an absolute power of revocation, he is to be still deemed the absolute owner of the estate conveyed, so far as the rights of creditors and purchasers are concerned." New York Real Property Law $\$ 145$ (1945).

32. In cases where creditor's rights are concerned the court has been loath to say that the settlor reserved so much power as to constitute the trustee his agent. In Fidelity Trust Co. v. Union. Bank, supra note 27 in addition to the absolute power to revoke, the settlor reserved the right to "sell, assign or hypothecate . . . to exercise an option or privilege granted by any of said policies.. to receive all payments, dividends, surrender values, benefits, privilege of any kind which may accrue on account of any of said policies." (313 Pa. at 483, 169 Atl. 216, Emphasis Added) but the trust was nevertheless said not to be "testamentary." If the settlor totally fails to create a trust as by failing to name a beneficiary during his life, the res. will of course be reachable by his creditors. Kenin's Trust Estate (No. 1) supra note 30.

33. Tunnel's Estate, 325 Pa. 554, 190 Atl. 906 (1949). 
or not the settlor has adequately expressed his intention as the disposition of the property after his death, the agency test results in permitting some dispositions of property which are clearly in the teeth of the statute, and in forbidding others where the settlor has for all practical purposes complied with the policy of the statute. Thus if A transfers property to $T$ upon a revocable oral trust for himself for life, remainder to $C, C$ will face no statute of wills problem in enforcing the trust after $A$ dies under the present state of the law. ${ }^{34}$ If, however, in addition to the power to revoke A reserves such powers over the administration of the res as would constitute $\mathrm{T}$ his agent, $\mathrm{C}$ would be barred from enforcing the trust by the statute of Wills because the trust was "testamentary"."35 From the point of view of the statute of wills, it would appear that neither of these postmortem distributions should be permitted because in both cases the settlor has potential control over the property during his life and in effect is achieving a "testamentary" disposition of his property without an instrument satisfying the statute of wills. The danger of perpetrating a fraud on A's estate arises not from the fact that in the second case A reserved greater power over the res, but rather from the fact that in both cases the trusts are oral. Where there is a writing which satisfies the Statute of Wills, the possible result from applying the "agency" test is even more anomalous. If, in the illustration above, the facts are the same except that the trust is created by an instrument signed by the settlor, there is little doubt that $\mathrm{C}$ would get the property in the first example. In the second case, C's interest is more doubtful. A residuary legatee of the settlor or his heir could argue; (1) the trust was not valid inter vivos because the trustee was merely the settlor's agent; (2) it is not valid as a will because the in praesenti language in the deed of trust indicates that the settlor did not execute the deed "animo testando". The result of applying the present "agency" test might be that the trust is invalid inter vivos because "testamentary" and invalid as a will because executed without the necessary "testamentary" intent. ${ }^{36}$ If, in such a case, the court concerned itself not with whether or not the trustee is the "agent" of the settlor, but rather with whether or not the settlor has, consistently with the policy of the Statute of Wills, adequately expressed his intention as to the disposition of the property after his death, they might either (1) direct that the

34. Restatemrent, Trusts, §57 Comment (a) Illustration 1, (1934).

35. Ibid, \$57, comment (g).

36. This is substantially what seems to have happened in McEvoy v. Boston Five Cent Savings Bank, 201 Mass. 50, 87 N.E. 465 (1909). In this case the instrument creating the trust was signed by the settior and three attesting witnesses as required by the Mass. Statute of Wills (R.L. Mass. Chap. $135 \$ 1,1902$ ). The court held that in view of the large powers reserved the trust was "testamentary" and invalid inter vivos. The court then stated that the instrument was invalid as a will, citing cases where the instrument creating the "testamentary" trust did not have a sufficient number of attesting witnesses to be a good will, to prove that this instrument, which had the requisite number of witnesses, was invalid as a will. The only real difficulty with the instrument as a will was that the words of present transfer tend to negative the required testamentary intent. 
instrument be probated as a will, ${ }^{37}$ or; (2) simply hold the trust valid inter vivos.

Although the facts in the Sheasley case are easily distinguishable from the above illustrations, ${ }^{38}$ the court's emphasis on the creation of the trust by a written document may indicate an approach to the above -kind of reasoning. It may represent an abandonment of the "agency" test in cases where the only important policy involved is the Statute of Wills and that policy is satisfied by a writing signed by the settlor. Such a functional approach to the problem, it is submitted, is all to the good.

The conclusion which seems to follow from the above analysis of Pennsylvania cases dealing with the problem of whether or not revocable trusts created in the settlor's lifetime are "testamentary" is that the test propounded by the Restatement and followed by the Pennsylvania court is inadequate to meet the problems created by such trusts. In the case of inheritance taxation, to follow the agency test would be to subvert the entire policy of the inheritance tax statute, a fact which is recognized but only half-appreciated by the Pennsylvania court. In the case of the surviving spouse's right of election, application of the agency test did result in an emasculation of the policy of the election statutes until the legislature remedied the situation in 1947. In the case of creditors' rights, the agency test is still working injustices to bona fide creditors. In cases where the only policy involved is that of the Statute of Wills, the agency test results in holding valid some post-mortem dispositions of property which are clearly contrary to the policy of the statute, and invalidating others which clearly seem to meet the policy. From the point of view of the policies involved, it would seem helpful to abandon the talk of whether or not trusts created in the settlor's lifetime are "testamentary", and simply state that trusts are valid inter vivos regardless of how much control the settlor reserves, provided however that the res of any revocable trust is taxable at the settlor's death, reachable by his creditors during his life or at his death, reachable by a surviving spouse who elects to take against the will and provided in addition that no disposition of the res of a revocable trust shall be effective after the settlor's death unless spelled out in a writing which meets the requirements of the Statute of Wills.

37. Scott urges that such instruments should be admitted to probate. Scott, Trusts and The Statute of Wills, 43 Harv. L. Rev., 521, 534 (1930). One of the difficulties with this would be that the in praesenti language could easily be seized upon as a bar to probate. (in re Greenfields Estate, 14 Pa. 489, 502 (1850). Another difficulty is that if such instrument were treated as a verill, the standard revocation clause in the settlor's last will would often defeat the trust when the settlor didn't intend to revoke what he thought were valid trusts. The facts of Tunnells Estate supra note 4 are illuminating in this respect. There the trusts were created by instruments signed by the settlor and therefore in Pennsylvania meeting the minimum formal requisites of a will. There the court said that the trusts were invalid as "testamentary" but actually held that they were revoked by the phrase "all other wills Prior to this date made by me are Revoked" (325 Pa. at 560, 190 Atl. at 909). It is at least moot whether the testator intended that phrase to refer to the previously created trusts.

38. Supra note 6. The fact most embarrassing to the above theory is that the instrument creating the trust was signed by the trustees not the settlor. 